\author{
UNIVERSIDADE DE SÃO PAULO \\ INSTITUTO DE PSICOLOGIA \\ PROGRAMA DE PÓS-GRADUAÇÃO EM PSICOLOGIA \\ ESCOLAR E DO DESENVOLVIMENTO HUMANO
}

\author{
ANA PAULA STHEL CAIADO
}

\title{
A regra em jogo: um estudo sobre a prática de jogos de regras e o desenvolvimento moral infantil
}

(Versão Corrigida) 


\section{ANA PAULA STHEL CAIADO}

\section{A regra em jogo: um estudo sobre a prática de jogos de regras e o desenvolvimento moral infantil}

(Versão Corrigida)

Tese de doutorado apresentada ao Instituto de Psicologia da Universidade de São Paulo como parte dos requisitos para obtenção do título de doutor em Psicologia.

ÁREA DE CONCENTRAÇÃO: Psicologia Escolar e do Desenvolvimento Humano

ORIENTAÇÃO: Prof. ${ }^{a}$ Dra. Maria Thereza C.C. de Souza

Pesquisa financiada pela FAPESP

São Paulo

2012 
AUTORIZO A REPRODUÇÃO E DIVULGAÇÃO TOTAL OU PARCIAL DESTE TRABALHO, POR QUALQUER MEIO CONVENCIONAL OU ELETRÔNICO, PARA FINS DE ESTUDO E PESQUISA, DESDE QUE CITADA A FONTE.

Catalogação na publicação

Biblioteca Dante Moreira Leite

Instituto de Psicologia da Universidade de São Paulo

Caiado, Ana Paula Sthel.

A regra em jogo: um estudo sobre a prática de jogos de regras e o desenvolvimento moral infantil / Ana Paula Sthel Caiado; orientadora Maria Thereza Costa Coelho de Souza. -- São Paulo, 2012.

$124 \mathrm{f}$.

Tese (Doutorado - Programa de Pós-Graduação em Psicologia. Área de Concentração: Psicologia Escolar e do Desenvolvimento Humano) - Instituto de Psicologia da Universidade de São Paulo.

1. Jogo 2. Jogos de regras 3. Moral 4. Desenvolvimento infantil 5. Epistemologia genética I. Título.

HQ782 


\section{FOLHA DE APROVAÇÃO}

Ana Paula Sthel Caiado

A regra em jogo: um estudo sobre a prática de jogos de regras e o desenvolvimento moral infantil.

Tese de doutorado apresentada ao Instituto de Psicologia da Universidade de São Paulo como parte dos requisitos para obtenção do título de doutor em Psicologia.

ÁREA DE CONCENTRAÇÃO: Psicologia Escolar e do Desenvolvimento Humano

Tese defendida e aprovada em

Banca Examinadora

Prof. Dr.

Instituição Assinatura:

Prof. Dr.

Instituição Assinatura:

Prof. Dr.

Instituição Assinatura:

Prof. Dr.

Instituição Assinatura:

Prof. Dr.

Instituição Assinatura: 


\section{DEDICATÓRIA}

Aos profissionais da educação e psicologia que ainda acreditam e investem no rico potencial de nossas crianças.

Aos meus pais.

E ao Marcelo. 


\section{AGRADECIMENTOS}

Depois do empenho, apoio incondicional, afeto e energia de tantas pessoas envolvidas direta e indiretamente neste trabalho é chegada a hora de agradecer. Espero conseguir expressar minha eterna e imensa gratidão com estas poucas palavras...

Primeiramente e acima de tudo a Deus. Presença constante em todos os momentos. Luz que guia meus passos e abre caminhos, me fortalecendo para encarar desafios como este.

A Celso e Rita. Pais que me proveram dos bens mais valiosos, pois me fizeram entender que virtude e conhecimento engrandecem a alma e enriquecem muito mais do que qualquer aquisição material.

Patrícia, Andréia e Jackson, meus amados irmãos, pelo prazer de me permitirem partilhar desde meus pequenos tropeços até minhas grandes conquistas. Tenham certeza de que com vocês ao meu lado viver fica, não só menos complicado, como também muito mais feliz. Obrigada!!!

Ao Marcelo por ser meu refúgio e me proporcionar a certeza de que o amor tudo pode e tudo supera. Obrigada pelo cuidado, pelo carinho, pela confiança, pela sensibilidade, pela tolerância, pela cumplicidade, pelo entusiasmo, pela entrega, pela lealdade...

A Prof ${ }^{a}$ Dra. Claudia Broetto Rossetti, principal responsável (culpada mesmo) por tudo isto. Obrigada por exercer a docência tão doce e competentemente, a ponto de me fazer querer estudar por mais seis anos além da graduação.

Ao Prof ${ }^{\circ}$ Dr. Sávio Silveira Queiroz e ao Prof ${ }^{\circ}$ Dr. Lino de Macedo grandes mestres que me apresentaram a essência da teoria piagetiana não só por suas palavras, mas também em suas posturas diante o processo de conhecimento.

A minha prezada orientadora, Prof $^{a}$ Dra. Maria Thereza Costa Coelho de Souza. Renomada pesquisadora que me fez ver além, e deu a este trabalho o status de uma construção verdadeiramente pautada pela cooperação, no melhor dos sentidos dados por Piaget ao termo. Obrigada por tamanha paciência e imensa compreensão. Por renovar as fichas e apostar em momentos que nem mesmo eu acreditava possível.

Aos integrantes de minha banca de defesa, pelo comprometimento, primor e probidade ao avaliarem este trabalho. Em especial ao Prof $^{\mathfrak{o}}$ Dr. Yves de La Taille e a Prof ${ }^{\mathrm{a}}$ Dra. Betânia Alves Veiga Dell' Agli por me terem aberto preciosos caminhos em meu exame de qualificação.

Aos amigos. Que bom que são tantos que fica até difícil enumerar, de qualquer forma tentarei, correndo o risco de não ser extensiva o bastante: 
A Cida, Marcela e Olivia que me ajudaram a suportar e desfrutar São Paulo, durante meu primeiro ano de curso.

A Liana, por ter se feito tão presente, mesmo distante.

A Tais, Lu Miranda, Bela(s), Mila, Aline e Lu Dantas por me lembrarem que estudar demais também pode ser prejudicial a saúde e me proporcionarem alegrias indescritíveis.

E novamente a Tais e Marcela, por serem tudo isto que vocês são em minha vida.

Ao tio Jairo e Sueli, meus pais paulistas, por todo o afeto, atenção, zelo e carinho que recebi durante minha prolongada estadia. E aos novos tios, primos e sobrinhos que ganhei, por me deixarem fazer parte da família em tantos felizes momentos que compartilhamos.

A minha super prima-amiga-irmã Cinthia Caiado. E a todos os demais familiares que de uma forma ou outra participaram da elaboração deste trabalho. Seja literalmente tabulando os dados, calculando índices e montando tabelas ou simplesmente me incentivando e me divertindo quando a tensão aumentava para além da conta. Dedéia, Lele, Takinha, Rosfu, Jojovem, Renanzicos, Dado e tia Regina vocês são demais!!!!

Ao meu sócio-chefe-supervisor e grande amigo Gerson Abarca, por ter promovido (e ainda promover) todo o apoio técnico e emocional de minhas empreitadas profissionais.

Às minhas alunas, que se tornaram auxiliares de pesquisa e depois amigas, muito obrigada pelo comprometimento e dedicação. Já falei diversas vezes durante a coleta dos dados e reafirmo quantas vezes for preciso que não teria conseguido sem vocês. Jura, Fátima, Luana, Alzinete, Paula e Tainá que esta experiência tenha contribuído com a formação de vocês e possa lhes render frutos futuros. E que venham os artigos!!!

A todos os profissionais do Colégio São José, Colégio José Bonifácio e Cooperativa Educacional de Linhares por acreditarem que um autêntico processo de ensinoaprendizagem pode (e deve) ultrapassar os métodos didáticos, a sala de aula, o planejamento pedagógico e, por que não, atrapalhar a rotina. Em especial, a Lúcia, Cida, Betina, Andreza, Elisa, Adriana, Renata, Lurdinha, Bernadete e Shena por terem me recebido, confiado em minha proposta e, principalmente, me acolhido!

Aos meus pequeninos sujeitos de pesquisa que me divertiram muito e me ensinaram tanto.

Agradeço ainda a FAPESP. Instituição de renomada seriedade que, além de fornecer recursos financeiros, emprestou credibilidade e respeito, auxiliando-me a alcançar novos horizontes. Meus mais sinceros agradecimentos, não só por terem tornado esta pesquisa viável, mas por a terem tornado uma produção científica digna de confiança. 
"Impondo-se assim às consciências, a regra permanece exterior a elas e é, de fato, muito mal observada. (...). No momento em que esta mesma regra intervém como condição de cooperação, isto é, quando as crianças a praticam entre si, não somente ela é mais bem compreendida como verdadeiramente aplicada. Há, então, dois tipos de regras que acompanham os dois respeitos: a regra exterior ou heterônoma e a regra interior. Somente a segunda conduz a uma real transformação do comportamento espontâneo."

Jean Piaget, 1930. 


\section{RESUMO}

CAIADO, A.P.S. A regra em jogo: um estudo sobre a prática de jogos de regras e o desenvolvimento moral infantil. 2012. 121 f. Tese (Doutorado) - Instituto de Psicologia, Universidade de São Paulo, São Paulo.

Sendo a consciência e a prática das regras fatores relevantes para a compreensão do desenvolvimento moral, os diferentes contextos que envolvem o jogar com regras, podem revelar-se espaços privilegiados para o estudo da moralidade infantil. De acordo com a abordagem psicogenética piagetiana, o jogo ao possibilitar a livre construção do conhecimento e estimular trocas sociais cooperativas, pode vir a favorecer a superação do egocentrismo moral e intelectual, aspecto este indispensável à construção de juízos morais autônomos. Optou-se no presente estudo por focalizar mais diretamente a relação da criança com a regra em diferentes situações, utilizando-se o jogo como pretexto para o estudo desta relação. O próprio Piaget em seu texto de 1932 usa um jogo de regras para estudar a moralidade e defende esta atividade como uma instituição genuinamente infantil propícia ao desenvolvimento do respeito mútuo e do estado cooperativo fundamental a autonomia. Posto isto, a presente pesquisa teve como objetivo investigar diferentes formas de interação da criança com a regra em contextos de jogo, articulando-as com o desenvolvimento moral infantil, segundo o referencial psicogenético piagetiano. Participaram da pesquisa 64 crianças com idades entre 07 e 08 anos, divididas em 14 grupos com, em média, quatro componentes cada. Foram aplicadas diferentes situações de contato com regras, sendo que na primeira as crianças jogaram conforme regras prescritas pela experimentadora (situação fechada), na segunda havia a possibilidade da criança intervir e propor novas formas de jogar (situação intermediária) e na terceira foi solicitado que inventassem um jogo com o material fornecido. Foi realizada uma sessão semanal para cada modalidade de contexto descrita, com cada grupo, sendo uma por dia, durante três semanas. Concluída a aplicação dos diferentes contextos de regra, os sujeitos passaram por uma entrevista clínica, na qual foram investigadas suas concepções relativas à regra moral em contraposição a regra do jogo. A sistematização de todo o material coletado consistiu em análises exploratórias a partir da categorização das ações adotadas pelos sujeitos, principalmente aquelas de caráter mais social como, por exemplo, troca de ideias, uso das regras, consideração da perspectiva alheia, interajuda, realização de acordos consensuais, resolução de conflitos, tomadas de decisão, emissão de julgamentos, entre outras. Tais categorias foram então convertidas em indicadores empíricos, com os quais foi possível delimitar três vias de análise: relações entre indicadores; relações entre contextos e acompanhamento individual de cada sujeito. Os resultados demonstram diferentes manifestações de uso e compreensão da regra de acordo com cada contexto analisado, com maiores evidências de autonomia nas situações que propiciavam acordos mútuos e exigiam de forma mais acentuada a relação entre pessoas. Buscou-se, a partir da presente pesquisa, evidenciar aspectos relevantes da relação da criança com a regra no contexto de jogo, entendendo-a como parte importante de seu desenvolvimento moral. São discutidas, assim, algumas interfaces entre o jogar e a moralidade, tomandose como base os usos e concepções infantis a respeito da regra.

Palavras-chaves: Jogo, regras, moralidade, desenvolvimento infantil, Epistemologia Genética. 


\begin{abstract}
CAIADO, A.P.S. The rule at stake: a study about rules games practice and the child moral development. 2012. 122 f. Tese (Doutorado) - Instituto de Psicologia, Universidade de São Paulo, São Paulo.

Being the conscience and the rules practicing relevant issues in the understanding of the moral development, the different scenes regarding the playing with the rules, could reveal themselves privileged spots for the childhood morality. According to the Piaget psychogenic, the game, as it makes possible the free knowledge construction and estimulate social collaborating exchanges, could encourage the overcoming of the moral and intellectual egocentrism, indispensable issue for the contruction of moral autonomic judgements. It was decided in this study to focus more directly on the child's relationship with the rule in different situations, using the game as an excuse to study this relationship. Piaget himself, in his 1932 texts, uses a rule game to study the morality and defend this activity as a genuine child institution wich provides the mutual respect development and the collaborating state, essential to the autonomy. Once exposed, the present research has the purpose to investigate different ways of child interactions with rules in games scenarios, combining them with the child moral development, following the piagetian model. In the research, 64 children in their 7 to 8 years participated, divided in 14 groups of 4 members each, on the average. It was applied different rule contact situations: in the first, the children played according the rules described by the experience instructor (close situation), in the second one, there was the possibility of the child to intervene and suggest new ways of playing (intermediary situation) and in the third one was solicited that the children invent a game with the provided material. It was realized a weekly session to each scenario described, in each group, once a day along three weeks. Once finished the different contexts applications, the subjects received a clinical interview, where their statements regarding moral rules in opposite to game rules was investigated. The construction scheme of the collected material was based in exploration analysis by the categorization of the adopted actions, mainly the actions with social intents as, for an example: ideas exchange, rules usage, another point of view consideration, interpeople helping, consensual agreements realizations, conflicts resolutions, decision choices, judgment states, among others. The categories was converted in empirical indicators, making possible to delimit three analysis ways: relation between indicators, relation between contexts and individual follow up of each subject. The results demonstrates different manifestations of the usage and rule understanding according to each analyzed context, with more evidence of autonomy in situations that provided mutual agreements and demanded more sharply the relationship between people. It was searched, by the present research, to evidence relevant matters in the child relation with the rule in a game context, understanding the rule as a important part of his moral development. Some interfaces between the play and morality are discussed, taking as a basis the uses and children's conceptions about the rule.
\end{abstract}

Key-words: Games, rules, morality, child development, Genetic Epistemology 


\section{SUMÁRIO}

1. APRESENTAÇÃO.

2. INTRODUÇÃO 19

2.1- O jogo e a regra 19

2.2- A moral e a regra 22

3. FUNDAMENTAÇÃO TEÓRICA 29

3.1-Aspectos do desenvolvimento humano na perspectiva piagetiana 29

3.2- Jogo e moralidade em Piaget 34

4. O CONTEXTO DE PESQUISAS SOBRE JOGOS E MORALIDADE: UMA BREVE REVISÃO

5. DELIMITAÇÃO DO PROBLEMA E JUSTIFICATIVA 53

6. MÉTODO 57

6.1- Participantes 57

6.2- Instrumentos e Procedimentos de coleta 57

6.3- Procedimentos para a análise dos dados 60

7. RESULTADOS E DISCUSSÃO 68

7.1- Análise dos Contextos 68

7.1.1 - Quanto à ocorrência dos indicadores 68

7.1.2 - Quanto aos critérios estabelecidos para classificação da amostra em níveis 
7.2.2- Por situações concretas de jogo 84

7.2.3- Pela comparação entre situações hipotéticas e reais 89

7.3- Análise da regra associada a conteúdos morais .98

8. CONSIDERAÇÕES FINAIS 102

9. REFERÊNCIAS 109

ANEXO 01 - Protocolo do contexto 03 (situação aberta) 117

ANEXO 02 - Roteiro da entrevista clínica 118

ANEXO 03 - Situação Fechada (jogo Ludo) 122

ANEXO 04 - Situação Intermediária (jogo Uno)

ANEXO 05 - Planilhas de tabulação dos dados (em CD-ROM) 124 


\section{LISTAS}

\section{FIGURAS}

Figura 01 - Gráfico de acompanhamento individual do sujeito 08 (KAT).

Figura 02 - Gráfico de acompanhamento individual do sujeito 11 (JOA).

Figura 03 - Gráfico de acompanhamento individual do sujeito 24 (JOA).

Figura 04 - Gráfico de acompanhamento individual do sujeito 33 (IZA).

Figura 05 - Gráfico de acompanhamento individual do sujeito 49 (PED).

Figura 06 - Gráfico de acompanhamento individual do sujeito 51 (ART).

Figura 07 - Gráfico de acompanhamento individual do sujeito 27 (ART).

Figura 08 - Gráfico de acompanhamento individual do sujeito 48 (BRU).

Figura 09 - Gráfico de acompanhamento individual do sujeito 20 (GUS).

Figura 10 - Gráfico de acompanhamento individual do sujeito 12 (ANA).

Figura 11 - Gráfico de acompanhamento individual do sujeito 17 (ISA).

Figura 12 - Gráfico de acompanhamento individual do sujeito 06 (TAL).

Figura 13 - Gráfico de acompanhamento individual do sujeito 43 (SAR).

Figura 14 - Gráfico de acompanhamento individual do sujeito 21 (ANA).

Figura 15 - Gráfico de acompanhamento individual do sujeito 52 (ANA).

Figura 16 - Gráfico de acompanhamento individual do sujeito 22 (GAB).

Figura 17 - Gráfico de acompanhamento individual do sujeito 40 (ERI).

Figura 18 - Gráfico de acompanhamento individual do sujeito 10 (REN).

Figura 19 - Gráfico de acompanhamento individual do sujeito 09 (CLA).

Figura 20 - Gráfico de acompanhamento individual do sujeito 39 (LUI).

Figura 21 - Gráfico de acompanhamento individual do sujeito 15 (ENZ).

Figura 22 - Gráfico de acompanhamento individual do sujeito 54 (MAR).

Figura 23 - Gráfico de acompanhamento individual do sujeito 23 (CAR).

Figura 24 - Gráfico de acompanhamento individual do sujeito 63 (EST).

Figura 25 - Gráfico de acompanhamento individual do sujeito 16 (HAL).

Figura 26 - Gráfico de acompanhamento individual do sujeito 47 (MAR).

Figura 27 - Gráfico de acompanhamento individual do sujeito 18 (MAT).

Figura 28 - Gráfico de acompanhamento individual do sujeito 29 (GAB).

Figura 29 - Gráfico de acompanhamento individual do sujeito 38 (ISA).

Figura 30 - Gráfico de acompanhamento individual do sujeito 05 (ANE). 


\section{LISTAS}

\section{QUADROS}

Quadro 01 - Descrição dos indicadores dos jogos por níveis

Quadro 02 - Descrição dos indicadores das entrevistas por níveis

\begin{tabular}{|l|l|}
\hline TABELAS & 69 \\
\hline Tabela 01 - Distribuição da frequência dos indicadores por contexto. & 72 \\
\hline Tabela 02 - Distribuição da amostra segundo os três critérios de classificação. \\
\hline Tabela 03 - Distribuição das crianças em níveis quanto à relação com a regra e relação entre pessoas. \\
\hline Tabela 04 - Distribuição das crianças em níveis quanto a relações com a regra e ações no jogar \\
\hline Tabela 05 - Distribuição das crianças em níveis quanto à situação fechada e situação aberta. \\
\hline Tabela 06 - Distribuição das crianças em níveis quanto à situação fechada e situação hipotética. \\
\hline Tabela 07 - Distribuição das crianças em níveis quanto à situação aberta e situação hipotética. \\
\hline Tabela 08 - Distribuição das crianças em níveis quanto a relações com a regra e situação hipotética. \\
\hline Tabela 09 - Distribuição das respostas para cada conceito avaliado na situação hipotética. \\
\hline
\end{tabular}




\section{APRESENTAÇÃO}

Longe de desconhecer os padrões e critérios exigidos na redação de um texto acadêmico, peço licença para neste momento me pronunciar em primeira pessoa.

A presente pesquisa vem ao encontro de um profundo interesse pelo desenvolvimento infantil e mais diretamente pela Epistemologia Genética de Jean Piaget. Tendo em conta a demasiada abrangência de ambos os temas, prioriza aspectos sócio-morais e toma como referência para sua abordagem o estudo da relação da criança com a regra em diferentes contextos ${ }^{1}$.

Esse interesse esteve presente em todo meu percurso profissional e acadêmico, o qual foi marcado por recorrentes inserções no meio clínico e educacional, e invariavelmente pelo trabalho com crianças, sendo este em boa parte, senão todo, embasado por preceitos construtivistas.

Em termos acadêmicos constitui a possibilidade de aprofundamento de estudos realizados em minha iniciação cientifica, na qual realizei pesquisas sobre a preferência lúdica infantil, e em meu mestrado, onde pude investigar a inserção de jogos de regras no cotidiano escolar como recurso a promoção de relações cooperativas.

No entanto, a escolha por abordar o desenvolvimento infantil em seus aspectos sociais e morais por meio da teoria piagetiana decorre não somente de caminhos percorridos, mas também de novos horizontes a serem traçados. Além de unir esforços na consolidação de um campo de pesquisa não priorizado por Piaget, embora não desconsiderado por ele, o presente trabalho ao discutir a relação da criança com a regra em diferentes contextos e o jogar como situação propícia ao estudo desta relação, trata de dois assuntos muitas vezes mal interpretados em sua teoria, a saber: a influência do

\footnotetext{
${ }^{1}$ Cabe ressaltar, já de início, que o uso do termo "contexto" refere-se, exclusivamente, aos recortes situacionais realizados no estudo, não incluindo características socioambientais mais amplas, atreladas aos contextos de vida dos participantes. Desta forma, será utilizada ao longo do texto como sinônimo de modalidades ou situações de jogo propostas.
} 
contexto e o uso do jogo. Ambos constituem elementos cruciais para esta pesquisa e, por isso, serão devidamente debatidos em alguns momentos do texto que ora lhes apresento.

Não obstante, a título de adiantamento e esclarecimento, julgo importante tecer alguns comentários a este respeito. Embora muito se fale (e se escreva!) sobre a pouca evidência dada aos fatores socioambientais nos escritos de Piaget, e realmente este nunca foi seu foco prioritário, encontra-se embutida na maior parte de suas conceituações a participação de tais fatores. Aliás, se assim não fosse, haveríamos de nos perguntar de onde vem o caráter interacionista de sua teoria. O conceito de equilibração, por exemplo, que exprime a própria concepção piagetiana de desenvolvimento, refere-se a um movimento de aperfeiçoamento ou reestruturação frente a uma perturbação, ou seja, requer a articulação de fatores externos com mecanismos internos.

O segundo tema nos interessa mais de perto. É extremamente rica e diversificada a produção acadêmica sobre o jogo e com o uso de jogos. É igualmente rica, diversificada e inegável a gama de benefícios e contribuições que o jogo fornece para o desenvolvimento da criança. Percebe-se, todavia, que muitas vezes ele é tido como o instrumento provocador ou causador das mudanças e evoluções pretendidas, como se bastasse por si só o ato de jogar para a aquisição das noções investigadas ou resolução das problemáticas levantadas. Desconsidera-se muitas vezes que, em se tratando de uma perspectiva piagetiana, o papel do sujeito assimilador e o momento do desenvolvimento em que ele se encontra tornam-se fundamentais. Dito de outra forma, é preciso considerar que modificações e estímulos do meio só funcionam como agentes de desenvolvimento se associados à tomada de consciência individual, isto é, somente 
servirão como fonte de novas construções os componentes da experiência que se tornaram observáveis para o sujeito, no sentido piagetiano do termo.

Sendo assim, um ponto crucial de debate na formulação desta pesquisa foi o status que seria dado ao jogo de regras. Julgou-se importante definir se ele funcionaria como instrumento metodológico para o estudo do juízo moral ou seria entendido como espaço contributivo ao desenvolvimento destes juízos (enquanto condição necessária e não suficiente). Embora ambas vertentes sejam condizentes - o próprio Piaget em seu texto de 1932 usa um jogo de regras para estudar a moralidade e defende esta atividade como uma instituição genuinamente infantil propícia ao desenvolvimento do respeito mútuo e do estado cooperativo fundamental a autonomia - optou-se no presente estudo por focalizar mais diretamente a relação da criança com a regra em diferentes situações de jogos (concretas e hipotéticas), que por sua vez funcionariam como pretexto para o estudo do desenvolvimento moral e não necessariamente como mecanismo propiciador deste. Evita-se com isso também a ideia de causalidade direta discutida acima e contraditória com a perspectiva piagetiana.

Ficou esclarecido, portanto, que no lugar de uma abordagem generalista da moralidade, esta seria estudada a partir da relação da criança com a regra e que o jogo de regras, antes de ser entendido como mecanismo propiciador do juízo moral, na verdade funcionaria como pretexto para o estudo do mesmo. Neste ínterim, as intervenções com jogos ao invés de servirem como dispositivos de cunho experimental (com grupo controle e comparações inter-grupais), seriam delineadas como etapas de um estudo follow-up, direcionadas a analisar as mudanças e diferentes reações dos sujeitos ao longo do período de intervenção.

Feita a breve apresentação dos caminhos e propósitos embutidos na configuração desta pesquisa, passo a relatar como a mesma foi organizada textualmente. 
Inicialmente serão discutidas algumas formulações e concepções sobre o jogo e a moralidade em diversos campos de conhecimento. Em seguida, será apresentado o embasamento teórico, que se divide numa primeira parte onde se expõe, em linhas gerais, a concepção piagetiana de desenvolvimento e outra dedicada à explanação de alguns conceitos piagetianos diretamente vinculados a nosso tema. $\mathrm{O}$ tópico seguinte refere-se à revisão bibliográfica, na qual são apontadas as contribuições de trabalhos acadêmicos para a formulação de nosso problema de pesquisa, dando-se destaque àqueles que abordam o papel das trocas sociais no contexto de jogo e, em menor número, os que discutem os princípios normativos do desenvolvimento moral. Concluída a etapa de fundamentação teórica do trabalho, faz-se necessário posicioná-lo quanto aos objetivos e hipóteses em jogo, desta forma no tópico intitulado "Delimitação do problema e justificativa" estão explicitadas as diretrizes, premissas e propósitos envolvidos na elaboração de nossa tese. No Método encontram-se detalhados os procedimentos de coleta e análise dos dados, assim como justificados os critérios utilizados para o delineamento amostral. Na sequência o texto apresenta a discussão dos resultados, onde se propõe os dados organizados em dois eixos: análise dos contextos e análises individuais, estas divididas em comparações entre categorias, entre situações de jogo e entre contextos concretos e hipotéticos. Finalmente, em nossas considerações finais são expostos alguns pontos de articulação entre os resultados e retomadas nossas principais explanações sobre o tema. Desta forma, são discutidas questões sobre as influências contextuais em contraponto às capacidades individuais, sobre a interface prática e consciência da regra em suas diferentes manifestações e sobre a participação da relação interpessoal na relação com a regra. 


\section{2- INTRODUÇÃO}

Jogar constitui um dos fenômenos socioculturais mais importantes da história da humanidade. Amplamente reconhecidos por suas contribuições afetivas, sociais e cognitivas, os jogos são temas recorrentes de trabalhos na área de Psicologia e Educação. Nesse contexto, o jogo é geralmente estudado em termos de suas influências ou contribuições para diversos fenômenos, como, por exemplo, a representação mental, a linguagem, a aprendizagem, sem contar a vasta gama de noções e conceitos aos quais são, geralmente, associados.

A presente pesquisa compartilha de semelhante intento ao propor analisar, por meio do jogo de regras, diferentes maneiras de as crianças praticarem, assimilarem e respeitarem a regra, buscando com isso abordar aspectos do desenvolvimento moral infantil, segundo a teoria piagetiana.

Neste objetivo encontram-se reunidas duas importantes vertentes pesquisadas por Piaget ao longo de sua obra, que ao buscar explicações sobre como se dá a compreensão da realidade pela criança, não deixou de abordar as relações sociais inerentes a este processo e, com isso, considerar alguns meios que as possibilitam e os fins a que se destinam. Dentre tais considerações daremos destaque ao jogo de regras como espaço de trocas interindividuais igualitárias e estas como importantes para o desenvolvimento moral.

\subsection{O jogo e a regra}

O campo de pesquisa com jogos comporta, atualmente, temas partidários da Antropologia, Filosofia, Sociologia e, é claro, também da Psicologia. Com relação a esta última, vemos importantes contribuições do uso do jogo para o estudo de aspectos 
cognitivos, afetivos, sociais, morais, simbólicos, comportamentais, entre outros. Ademais, encontramos extensa e variada produção teórica sobre jogos em todas estas áreas do conhecimento.

Huizinga (1938/1993), por exemplo, aborda o jogo numa perspectiva histórica, considerando-o como fenômeno cultural e caracterizando-o por sua temporariedade. Para este autor, é jogo aquilo que evade o cotidiano, aquilo que se situa fora da vida "comum", atividade livre e desinteressada que arrebata o indivíduo a suprimir, dentro de limites de espaço e tempo previamente definidos, o mundo habitual. O próprio ato de jogar e as diferentes possibilidades do jogador fazem da atividade algo relativo, envolto em mistério.

Ideia semelhante encontramos em Chateau (1987) que, defendendo uma perspectiva desenvolvimentista, ressalta no jogo condições de distanciamento da realidade e artifícios de abstração que fazem dele um espaço único, um domínio demarcado e imediato, destinado ao exercício das condutas superiores, isto é, à aprendizagem da atividade adulta. "Tudo se passa como se o jogo operasse um corte no mundo, destacando do ambiente o objeto lúdico para apagar todo o resto. (...). O jogo constitui, assim, um mundo à parte que não tem mais lugar no mundo dos adultos; é um outro universo". (Ibid., p.21).

Por funcionar como elemento de formação para a vida futura, o jogo conta também com um caráter de seriedade, que propicia à criança mobilizar suas forças, afirmar suas conquistas e proclamar sua autonomia. "O mundo do jogo é, então, uma antecipação do mundo das ocupações sérias" (Ibid., p. 22).

Comumente usado com conotações diversas, o termo jogo acaba, por muitas vezes, tornando-se impreciso. Segundo Kishimoto (1998), a variedade de fenômenos considerados como jogo torna complexa a tarefa de defini-lo, isso porque "uma mesma 
conduta pode ser jogo ou não-jogo, em diferentes culturas, dependendo do significado a ela atribuído" (p. 02).

Algumas tentativas de classificações podem, entretanto, ser encontradas na literatura sobre o tema. A diferenciação proposta por Macedo (2005) coloca o jogar como um sucedâneo do brincar, o primeiro contaria com uma demarcação de regras e objetivos não encontrada no segundo, que seria caracterizado por livres composições.

$\mathrm{Na}$ verdade, a maioria dos teóricos que estudam o jogo prefere estabelecer distinções quanto ao tipo de característica, conteúdo ou estrutura presente. É o caso do já citado Huizinga (1938/1993) que propõe uma divisão entre jogos de representação, competição, atitude e atmosfera; ou de Callois (apud Rabioglio, 1995) que sugere quatro classes (competição, sorte, simulacro e vertigem) e dois extremos (diversão/fantasia X regras/obstáculos). Temos, ainda, a categorização proposta por Wallon (apud Kishimoto, 1998) entre jogos funcionais, de ficção, de aquisição e de fabricação e a do próprio Piaget (1946/1978), que apresenta as estruturas de exercício, símbolo e regra, as quais retomaremos adiante.

Para o que nos cabe neste momento basta salientar que o jogar com regras envolve uma realidade regulada por convenções que garante e organiza a convivência coletiva, possibilitando a cooperação. A interação social no jogo propiciaria um uso mais circunstancial da regra e o desenvolvimento de comportamentos em conformidade com ela. Dessa forma, o jogo de regras seria favorável ao estabelecimento de relações cooperativas por permitir regulações recíprocas com base em convenções mutuamente consentidas.

Considera-se, portanto, que a regra serve aos jogadores como ponto de referência para a realização de coordenações de ações ou trocas de ideias com base na reciprocidade. Não é senão por outro motivo que Piaget localiza o jogo de regras como 
estrutura de estágios mais avançados do desenvolvimento, ligada, entre outros fatores, a descentração, isto é, a capacidade de considerar a perspectiva alheia.

Cooperação e descentração são conceitos fundamentais da teoria piagetiana e inspiram diversos trabalhos que, como este, focam as vertentes sócio-morais do desenvolvimento. É o caso, por exemplo, de Selman (apud FONTES, 2004 e OLIVEIRA, 2005) que estudou a evolução da adoção de papéis sociais, ou seja, como progride a consideração de diferentes perspectivas, ao que denominou Tomada de Perspectiva Social. Para tanto, avaliou, por meio de situações-problema, a capacidade de resolver conflitos e compreender relações sociais de indivíduos em diversas faixas etárias. Segundo Oliveira (2005), "Selman chegou à elaboração de níveis de capacidade de assumir a perspectiva alheia, concomitantes e solidários aos níveis cognitivos propostos na teoria piagetiana, próprios à criança e ao adolescente" (p. 117). As capacidades de regulação social abordadas em seu trabalho são importantes não somente em nossa análise sobre o jogo, mas se fazem igualmente relevantes para o tema da moralidade, como discutiremos adiante.

\subsection{A moral e a regra}

A moralidade, assim como o jogo, vem sendo historicamente estudada como aspecto inerente à humanidade e é também alvo do interesse de ciências diversas. Assim, enquanto algumas correntes filosóficas buscam teorizar sobre os valores e princípios morais universais, os sociólogos enfatizam o pensamento moral em caráter coletivo, ficando a cargo dos psicólogos uma preocupação maior (mas não exclusiva) em relação ao desenvolvimento da consciência moral individual.

Daremos destaque dentre os representantes da sociologia àquele que foi fonte de reflexões para o próprio Piaget em suas sistematizações a respeito do tema. Assim, 
proporemos, em nossa tentativa de análise, uma breve exposição das conceituações propostas por Émile Durkheim.

Durkheim, como sociólogo que era, desenvolveu seus preceitos pautado na crença de uma moralidade imposta pelo grupo e, portanto, proveniente da internalização dos fatos sociais, que uma vez constituídos como unidade, estabeleceriam uma moral igualmente única. Estipula, assim, como mecanismo de legitimação moral o contato com o ser coletivo, entidade esta transcendente ao sujeito e capaz de despertar o sentimento do sagrado, um misto de obrigatoriedade e desejabilidade que levaria o indivíduo ao cumprimento de seu dever. (DURKHEIM, 1924/1994, 1925/2008)

Donde surgem duas constatações: primeiro que, ao postular uma origem externa (ser coletivo) para a moralidade, Durkheim (ibid.) retira do sujeito a possibilidade de uma autonomia normativa, o desenvolvimento moral corresponderia a um processo de disciplinarização advindo de instituições sociais (em especial a escola), no qual tornarse moral significa obedecer. Segundo, e mais importante aos objetivos deste texto, é que o conceito de sentimento do sagrado inclui em si a ideia de algo que conduz as ações do sujeito, submetendo-o às leis sociais sem que haja aí uma possibilidade muito clara de autorregulação consciente, ou seja, acaba por estabelecer uma moral atrelada aos desígnios da vida em sociedade.

Isto posto, façamos uma breve articulação com a abordagem piagetiana. Piaget credita, desde o início de sua teoria, à dimensão intelectual a função de adaptar o indivíduo ao meio, sendo ela instrumento essencial para interpretação dos fatos da realidade, dentre os quais se inclui, obviamente, os relativos à moralidade. Em suas considerações a respeito do tema concebe duas formas possíveis de legitimação das regras e valores morais, uma a partir da referência a figuras de autoridade constituindose, portanto heterônoma, e outra baseada na autonomia da consciência na qual o sujeito 
consegue prescindir de interferências externas. Nota-se aqui uma diferença com relação aos preceitos durkeimianos, no que toca a postulação de uma forma moral relacionada à autorregulação individual da consciência, a qual retira da sociedade a possibilidade única de legitimação colocando-a no próprio sujeito. Dessa forma, o sentimento de obrigatoriedade que levará este sujeito a cumprir o que considera seu dever, decorrerá de valores conscientemente consentidos, passando-se do conformismo diante princípios recebidos de fora para a conformação interior destes mesmos princípios.

Tomando por base o campo da filosofia, alguns estudiosos piagetianos ressaltam nos preceitos acima descritos nítida influência kantiana. No sistema filosófico kantiano encontraremos uma moral baseada na razão, pautada por máximas passíveis de universalização que devem ser aceitas de forma livre e racional. Neste sentido, só é moral aquilo que me foi determinado por vontade própria e que, pela lógica, vale para todos, inclusive para mim. Cria-se, assim, um vínculo de obrigação com a lei moral que prescinde das contingências e costumes sociais para se subordinar a uma escala de valores determinados pelo querer e submetidos ao crivo da razão.

Tal similitude entre Piaget e Kant é analisada, por exemplo, por Freitas (2002). A autora considera a concepção de moralidade do primeiro uma revisão dos pressupostos levantados pelo segundo e tenta explicar o entendimento piagetiano das duas morais contidas na proposta kantiana, se referindo ao fato de Piaget conceber a autonomia como uma evolução da heteronomia, enquanto que para Kant esta última seria uma forma falseada de moralidade.

Também esboçando um quadro comparativo entre estes dois teóricos, temos o artigo de Queiroz, Ronchi e Tokumaru (2009), no qual são examinadas as apropriações piagetianas de termos da filosofia kantiana, proporcionando uma reflexão sobre a diferenciação entre as duas morais e a concepção de respeito fundamental para esta 
diferenciação. Dentre as proposições analisadas pelos autores, uma se mostra fundamentalmente útil ao nosso tema, que seria exatamente a articulação entre o conceito de regra em Piaget e a questão da razão prática pura em Kant. Expõem os autores que as proposições fundamentais desta última, isto é, sua divisão entre máximas (considerações subjetivas adequadas apenas ao próprio indivíduo) e imperativos ${ }^{2}$ (aquilo que estabelece a ação sob a ótica de leis objetivas e universalmente válidas), embasam a análise piagetiana sobre a prática e consciência das regras, a qual será descrita adiante.

Piaget ao fazer sua investigação sobre o juízo moral [...] pretende observar como os sujeitos lidam com as regras de acordo com cada idade e que tipo de obrigação às regras os incitam, se proposições subjetivas (máximas) ou leis práticas (imperativos). (ibid., p. 71).

Outro autor contemporâneo que apresenta discussões interessantes ao nosso tema é Macedo (1994) que, numa perspectiva construtivista piagetiana, se põe a pensar sobre a natureza das leis e das regras. Em seu texto são discutidas seis comparações entre estas duas instâncias, cuja função primordial seria a de organizar nossa experiência e nossos conhecimentos, sejam eles simbólicos, sociais ou lúdicos. Apresentaremos ao menos quatro das seis comparações propostas pelo autor.

Em primeiro lugar, cabe-nos refletir acerca desta função organizativa apontada por ele para ambas, a qual na verdade, difere em seus conteúdos, pois enquanto a ordenação pela lei coloca limites, contornos, a da regra prima as relações. Neste sentido, vincula-se à lei tudo aquilo que é da ordem da proibição, enquanto que o que se busca pela regra é a possibilidade de repetição, a regularidade. Daí o reconhecimento de um caráter histórico e motivado para a lei e arbitrário e convencional para a regra (ibid.).

\footnotetext{
2 Os imperativos podem ser hipotéticos, neste caso a regra se faz a partir da vontade de alcançar determinado fim (o querer determina a regra) ou categóricos, nos quais a regra é validada pela vontade enquanto vontade em si, sem referência a sua causalidade (é o querer que é determinado).
} 
Disto também decorre o fato de a lei ser motivada por sua transgressão, pela transposição de seus limites. Já a regra clama por obediência, sem a qual se perde seu valor como referência consensual. Com isso, apreendemos o que há de fundamental na diferenciação entre as duas e que nos inspira a investigar mais a fundo a natureza da segunda, que seja, a necessidade impositiva da lei contra o caráter construtivo da regra (ibid.). É exatamente, a possibilidade de autorregulação consciente que tornam as regras tão atrativas aos estudiosos do desenvolvimento humano, em especial aos psicólogos, diga-se de passagem.

Não se quer com isso, obviamente, fazer apologia ao extermínio das leis enquanto princípios organizativos, tão importantes à sociedade, quanto o são as regras. Buscamos simplesmente delimitar, uma vez almejada a compreensão do desenvolvimento moral infantil pela via da legitimação de princípios normativos, os motivos que nos fizeram voltar nossa atenção para a regra e não para a lei.

Recorrendo ao próprio Piaget, podemos encontrar em seu texto de 1965 uma interessante análise a respeito das relações entre moral e direito, onde discorre precisamente a respeito de seus limites e distinções, e da dificuldade de formulá-los em termos teóricos, por mais que os sejam detectados na prática quando delegamos ao direito as leis codificadas pelo Estado e à moral as obrigações não codificadas advindas do costume.

Pouco satisfeito com a superficialidade de tal distinção Piaget (ibid.) passa a discutir um rol de concepções apresentadas por autores dos mais diversos ramos do conhecimento, agrupando-os sob três vertentes: uma primeira que prevê a identidade de natureza entre a moral e o direito, caracterizando-os pela existência de regras sancionadas coletivamente, cuja diferença repousaria somente em seu grau de coordenação, onde ao segundo caberia uma maior regulamentação, enquanto a primeira 
seria mais difusa. Em outra vertente ele reúne os partidários de uma total desvinculação entre moral e direito, sendo estes compostos por regras completamente distintas tanto por seus temas quanto por suas estruturas.

Diante de posições tão extremistas, Piaget (ibid.) passa então a discorrer sobre autores que na tentativa de distinguir, acabavam por assinalar pontos comuns entre a moral e o direito para além de seus mecanismos diferenciadores, concluindo, com base neles e a partir de seu próprio ponto de vista, pela existência de certo grau de parentesco ou até mesmo um paralelismo entre tais instâncias, o qual ele defende a partir da gênese da obrigação da consciência e das relações afetivas elementares que intervêm nos fatos morais e nos fatos jurídicos.

Uma vez que nos deteremos em tais pontos no próximo capítulo, basta por ora comentarmos que a análise piagetiana da questão faz intervir um elemento psicológico fundamental a nossa discussão sobre a concepção da regra, ao delimitar que seja na moral, seja no direito (e de forma diferente para cada um destes campos), comparecem fatores de obrigatoriedade indispensáveis à definição dos fatos normativos em sua essência. Piaget (ibid.), nos mostra assim que o reconhecimento da lei no campo jurídico e o respeito que a precede no campo moral, são condições inerentes de sua existência. É, inclusive, pela diferenciação de tais fatores que ele marca a própria diferença entre a moral e o direito. Ficando a primeira, portanto, pautada pela relação de respeito e pela valorização interpessoal, e o segundo ligado ao reconhecimento e conservação de valores adquiridos segundo uma escala geral.

O reconhecimento de um poder sentido como válido [...] aparece assim como um produto de diferenciação a partir do respeito mesmo ou de uma fonte comum. Ora o respeito consiste, pois, num sentimento essencialmente pessoal, isto é, que avalia uma "pessoa" como tal, bem diferenciada dos outros indivíduos e considerada como um todo único. Ao contrário, o reconhecimento de uma autoridade julgada válida, de um direito, de uma lei, etc., são sentimentos impessoais, que não avaliam uma pessoa enquanto indivíduo, mas uma "função" ou um "serviço", quer dizer, um aspecto particular e abstrato da pessoa. (PIAGET, 1965/1973, p. 219) 
Por fim, se salienta os estudos de Turiel $(1984,2002)$ por constituírem auxílio fundamental para a compreensão do conhecimento social e da distinção proposta entre moralidade e convenção. Para este autor a vida social é guiada por processos racionais e a construção das categorias do conhecimento social começa bem cedo, em crianças bem pequenas (pré-escolares). Aos objetivos perseguidos neste trabalho importa, especialmente, suas formulações a respeito das diferenças e semelhanças entre juízo moral e conceitos convencionados pelo sistema social. Desta maneira, são estipulados três domínios que se desenvolvem paralelamente desde a infância: o pessoal, o convencional e o moral. É possível identificar em suas discussões a respeito das interrelações entre ação, pensamento e contexto cultural no desenvolvimento social uma vertente estruturalista e interacionista que vem ao encontro dos propósitos deste texto.

Sem desconsiderar a importância de uma explanação sobre o jogo e a moralidade que una as diferentes perspectivas supracitadas de modo interdisciplinar, mas como forma de atender aos limites e interesses do presente trabalho, voltaremos agora nossa atenção para o campo da psicologia, mais precisamente para a abordagem psicogenética de Jean Piaget, na qual, como afirmado inicialmente, é possível encontrar importantes teorizações a respeito do jogo e da moralidade, que nortearão o presente trabalho. 


\section{3- FUNDAMENTAÇÃO TEÓRICA}

\section{1 - Aspectos gerais do desenvolvimento humano na perspectiva piagetiana}

Neste ponto de nossa exposição tentaremos contextualizar os temas até então discutidos em meio às concepções essenciais de Piaget sobre o desenvolvimento humano. Buscaremos focar o processo em si sem nos atermos aos tipos de aquisições, noções e conteúdos abordados no decorrer de sua obra. Após o que apresentaremos sucinta articulação com a questão da socialização.

Influenciado por sua formação na área de Ciências Naturais, Piaget (1967/1973) entende que o funcionamento biológico e o mental são interdependentes, submetendo-se às mesmas leis. Ambos evoluem na direção de equilíbrios progressivos, a partir de atos de organização e adaptação ao meio. Esse processo de adaptação e organização intelectual se dá pelas ações físicas ou mentais sobre objetos, interação esta que entendida no contexto de perturbações, regulações e compensações pode resultar em construção de novos esquemas (PIAGET, 1975/1976). Um esquema, por sua vez, é aquilo que há de mais generalizável e transponível de uma ação a outra. São "instrumentos de adaptação", usados para assimilar o mundo e organizar a experiência (PIAGET, 1967/1973).

Vemos, com isso, que o sujeito se desenvolve a partir de sua atividade construtiva e que esta atividade ocorre em sua interação com o ambiente, ou seja, para conhecer é preciso construir e para construir é preciso interagir. Mas como se dão tais processos? Segundo Piaget de duas formas dialeticamente interligadas: integrando os dados da experiência aos esquemas já existentes (assimilação) e reconfigurando os esquemas frente à situação vivida (acomodação).

As informações discutidas até aqui - isto é, a correspondência entre fatores cognitivos e biológicos, a ação enquanto elemento construtivo, o meio como fonte de 
perturbações e a dialética entre acomodação e assimilação - vinculam-se, mesmo que indiretamente, aos diferentes fatores apontados por Piaget (1964/1989) para explicar o desenvolvimento, a saber: maturação, experiência, interação social e equilibração. Tomemos por ora esta última.

O conceito de equilibração sintetiza a tese piagetiana de desenvolvimento, representa seu caráter integrador e descreve seus principais mecanismos. Com ele Piaget (1975/1976) explica a construção do conhecimento como busca por aperfeiçoamentos progressivos, num interjogo entre observáveis e coordenações, onde os primeiros referem-se às constatações que o sujeito retira (ou crê retirar) da experiência e as segundas são as relações inferenciais que ele estabelece em sua interação com o objeto que implicam, para além da simples generalização, em novas construções.

O modelo da equilibração aponta também as diferentes formas de um indivíduo lidar com as modificações e instabilidades contextuais, e isto interessa sobremaneira aos objetivos deste trabalho. Segundo este modelo, modificações no ambiente podem gerar desequilíbrios que, quando notados, desencadeiam reações no sujeito provocando resultados diferenciados em termos de conduta. As primeiras são as chamadas regulações enquanto que aos últimos denominamos compensações. Assim, desde que uma variação ambiental (seja ela física ou social) se mostre perturbadora para o sujeito e uma vez que tal perturbação desencadeie regulações, estas poderão ter como efeito três tipos de conduta: negação da perturbação, sem mudanças no sistema (alfa); incorporação da perturbação enquanto variante, gerando remanejamentos parciais entre subsistemas (beta) ou integração operatória, possibilitada por antecipações e inversões (gama). A teoria da equilibração pode ser considerada, portanto, uma importante referência ao estudo de níveis diferenciados de conduta em relação às modificações ambientais. 
Igualmente importante para nossos propósitos é a visão piagetiana acerca da socialização. Nesta área são defendidos os mesmos princípios de adaptação, organização e equilibração expostos anteriormente. Assim como o conhecimento físico e o lógico-matemático, o conhecimento social se dá por mecanismos de regulação e compensação efetivados diante diversas qualidades de relações interindividuais. A este respeito podemos ainda ponderar que cada etapa evolutiva e até mesmo cada forma de pensamento a ela associada propiciará variados modos de interação e, consequentemente, diferentes graus de socialização. Embora concorde que o ser humano é um ser social, Piaget (1965/1973) salienta a insuficiência de tal premissa quando não acompanhada pela devida formulação sobre como o desenvolvimento é influenciado pela vida em comum.

Souza (2002) ao tratar desta questão, relembra que o foco piagetiano recai muito mais na capacidade assimilativa do sujeito do que nas propriedades estimuladoras dos objetos. Neste sentido enfatiza que, embora a interação social forneça elementos necessários a construção do conhecimento, como o favorecimento da não-contradição, ela não é suficiente, visto que não cria novas estruturas. Em outro texto no qual discute temática semelhante escreve:

[...] as transmissões sociais somente provocarão no sujeito efeitos compatíveis com o que ele é capaz de assimilar ativamente. O sujeito não é passivo às interferências sociais e culturais, da mesma forma que não o é aos estímulos do meio ambiente, mas reage àqueles que podem ser assimilados por seu sistema cognitivo. De acordo com esta visão epistemológica, aplica-se ao comportamento social os mesmos princípios da lógica da inteligência, quais sejam, os da composição e da reversibilidade [...]. (SOUZA, 1999, p.96)

Uma vez entendido o papel das interações sociais no desenvolvimento, cabe-nos refletir acerca de sua natureza e funcionamento. Em primeiro lugar, temos que o fator social de uma interação encontra-se vinculado à qualidade das relações estabelecidas entre os indivíduos, sendo que esta, por sua vez, dependerá de três critérios: a adesão a um sistema comum de referência, o reconhecimento e conservação da palavra 
empenhada e a consideração da perspectiva alheia. Com base nestes critérios é possível estabelecer uma escala de graduação das possibilidades de troca social que, associada à lógica do pensamento, parte do mais completo egocentrismo até a mais elaborada descentração. Desta forma, o grau máximo de socialização corresponderia à capacidade de relativizar o ponto de vista próprio e se posicionar em meio ao conjunto de outros possíveis, segundo as leis da reciprocidade. (PIAGET, 1965/1973)

Não são, entretanto, as condições cognitivas dos sujeitos em interação os únicos fatores concebidos por Piaget. O decurso de suas trocas depende também de mecanismos de regulação social, ou seja, elementos normativos que determinarão as formas pelas quais o acordo é estabelecido. Neste sentido, é preciso identificar por qual via a troca foi efetivada, se pela aceitação passiva por um das proposições enunciadas pelo outro ou se pela verdadeira coordenação de seus posicionamentos, o que nos dirá também sobre o tipo de regulação presente. No primeiro caso teremos uma relação de coação, a qual se baseia em uma assimetria de poder entre os participantes ligada, geralmente, a fatores de autoridade ou prestígio. Neste tipo de relação não há um verdadeiro intercâmbio de ideias e sim a transmissão de conteúdos entre um pólo dominante e outro dominado, que geralmente se restringe a reproduzi-los. As relações de coação se dão por pressão social, seus mecanismos de regulação são exteriores, não há nelas uma equivalência de posições que garanta a reciprocidade e o equilíbrio das trocas realizadas, assim sendo, o respeito entre os envolvidos na relação é unilateral, resultando em heteronomia. Sobre isto falaremos no tópico seguinte.

Tomemos agora a segunda possibilidade de realização de trocas sociais, aquela em que ocorre o verdadeiro equilíbrio. Ora basta tomarmos a própria definição sociológica do termo equilíbrio em um dicionário ${ }^{3}$, para apreendermos o essencial deste

\footnotetext{
${ }^{3}$ Dicionário Online Michaelis-UOL. <http://www.michaelis.uol.com.br>. Acesso em: 18/08/2012
} 
tipo de relação: "estado de integração em que tendências antagônicas ou competitivas se compensam reciprocamente". Vemos, portanto, que agora se trata de uma real coordenação de perspectivas, onde se busca a articulação e o entendimento mútuo, engendrados pela reciprocidade. Em uma perspectiva piagetiana, esta relação se dá entre dois ou mais indivíduos que co-operam, isto é, tentam ajustar, combinar, arranjar, sistematizar, harmonizar diferentes pontos de vista de forma coerente, segundo preceitos lógicos.

A relação cooperativa pode ser definida, então, como um sistema de operações interindividuais efetuadas em correspondência recíproca. Ela apresenta um caráter reflexivo e regulador que possibilitará a construção da consciência lógica e moral. Com isso, a atividade mental deixará de ser concreta e egocêntrica para se tornar abstrata e socializada. Desta maneira, através do exercício cooperativo, o pensamento alcançará um caráter operatório, da mesma forma que os sentimentos morais, acabarão por se inserir num contexto de regras coletivamente deliberadas e consentidas. Sobre as influências da cooperação nesses dois campos do desenvolvimento infantil Piaget (1972/1994) escreve:

Do ponto de vista intelectual é ela que está mais apta a favorecer o intercâmbio real do pensamento e da discussão, isto é, todas as condutas suscetíveis de educarem o espírito crítico, a objetividade e a reflexão discursiva. Do ponto de vista moral, ela chega a um exercício real dos princípios da conduta, e não só a uma submissão exterior. (p.182)

Tais conquistas seriam, então, representativas de um funcionamento autônomo, que se traduz no plano intelectual pela elaboração própria e espontânea dos princípios lógicos das operações, e no plano moral, pela compreensão interiorizada do caráter das regras a partir do reconhecimento mútuo dos motivos que as legitimam, possibilitando à criança alcançar, no primeiro plano, a reversibilidade, e no segundo, a reciprocidade (PIAGET, 1954/2001). 
Frente ao exposto, se ressalta a importância de entendermos o papel da troca social como subsídio para o desenvolvimento da inteligência, e da regra enquanto mecanismo regulador, pensando-a em contextos diferenciados quanto a suas configurações mais coercitivas ou cooperativas.

\section{2 - Jogo e moralidade em Piaget}

É chegado o momento de nos atermos aos componentes estruturantes de nosso estudo e compreendermos os diversificados meios de articulação entre eles que promoveram nossas reflexões sobre o tema. Será apresentado um pequeno ensaio sobre como o jogo e a moralidade são teorizados na abordagem piagetiana. Um proeminente ponto de intersecção entre tais aspectos, e eixo central do presente trabalho, é a concepção de regra. Concebida por Piaget (1932/1994) como essência da toda moralidade e estudada por ele como uma das estruturas do jogo - em conjunto com o exercício e o símbolo - a regra funciona como regulador das trocas sociais, determinando (ou restabelecendo) seu equilíbrio, encontra-se nela um sentido de obrigatoriedade que denota a existência de relações sociais (PIAGET, 1965/1973). Este caráter regulador da regra estaria, portanto, correlacionado ao tipo de comportamento social presente.

Piaget (1932/1994) identifica três tipos de situações sociais, com suas respectivas condutas que resultariam, respectivamente, em três diferentes tipos de regra: no estágio sensório-motor não se pode falar ainda de uma socialização efetiva da inteligência, a ausência de troca social descaracteriza a regra enquanto reguladora, esta se confunde com o hábito e o que se tem é mais um sentimento de regularidade; no período pré-operatório, o egocentrismo contribui para o estabelecimento de relações de coação, a regra possui assim um caráter coercitivo advindo do respeito unilateral, seu 
efeito regulador (se é que já se pode assim ser denominado) não funciona como meio de equiparação de posições ou equilíbrio da relação e sim como instrumento de submissão; a capacidade de pensar operatoriamente habilita a criança ao exercício cooperativo, ela agora é capaz de se relacionar de forma igualitária realizando coordenações de ações ou troca de ideias com base na reciprocidade, a regra torna-se então racional, submete-se ao crivo da objetividade e universalidade, sua função reguladora se dá como forma de se atingir o equilíbrio a partir de um engajamento mútuo e consensual.

O jogo de regras resultaria, portanto, da organização coletiva das atividades lúdicas, representando a exigência de reciprocidade social na medida em que instaura a regra como produto de uma regularidade imposta pelo grupo. Desse modo, constitui a atividade lúdica do ser socializado, o que explicaria seu desenvolvimento tardio e sua permanência após a infância (PIAGET, 1946/1978). Decorre, assim, da própria socialização e, portanto, do progressivo declínio do exercício e do simbolismo. Precisamente em virtude da regra, a assimilação ao eu característica deste último será substituída pela submissão do eu ao real, e a regularidade espontânea inerente ao primeiro será regulamentada em prol de objetivos estabelecidos. Em uma definição geral, os jogos de regras são,

[...] jogos de combinações sensório-motoras (corridas, jogos de bola de gude ou jogos com bolas etc.) ou intelectuais (cartas, xadrez etc.) com competição dos indivíduos (sem o que a regra seria inútil) e regulamentados quer por um código transmitido de gerações em gerações, quer por acordos momentâneos. (PIAGET, 1946/1978, p.184)

Deste modo as propriedades concernentes às estruturas de jogo anteriores - a regularidade do exercício e a fantasia do símbolo - serão correlacionadas pela assimilação recíproca, característica dos jogos de regras. Neste, a criança poderá conhecer as normas e limites presentes num contexto de socialização (MACEDO, 1995). 
Em texto mais recente Macedo (2009) apresenta uma excelente reflexão sobre o jogo de regras associados à teoria da equilibração. Em sua análise, coloca o jogo como um sistema de trocas e complementaridades que se realiza entre uma multiplicidade de aspectos internos e externos, entre fatores que desequilibram e invariantes que o caracterizam.

Objetivos, regras, objetos, estruturam física ou simbolicamente o sistema jogo. Mas, sua "vida" como objeto sociocultural só acontece se pessoas o jogarem, ou seja, assimilarem e acomodarem suas ações (ou melhor, seus esquemas de ações), nos limites de suas estruturas cognitivas e interesses afetivos. Sem a ação de um jogador é impossível ou sem sentido a ação do outro. (p.46)

Sendo assim, o jogo de regras, devido ao seu caráter coletivo e legislatório, acaba por reunir algumas das características relacionadas ao exercício cooperativo por excelência, isto é, a possibilidade de efetivar trocas igualitárias e definir acordos consensuais.

Tal modalidade de jogo foi também utilizada por Piaget (1932/1994) em uma de suas pesquisas sobre moralidade. Acreditando que a essência da moral deva ser estudada a partir do respeito que os indivíduos adquirem pelas regras, e que o jogo possui a peculiaridade de reunir regras estabelecidas nas relações entre crianças exclusivamente, ele buscou investigar as afirmações e ideias destas sobre as regras do jogo de bolinha de gude, analisando não só como elas as praticavam como também suas considerações a respeito de sua origem e obrigatoriedade, ao que denominou consciência das regras.

Seus resultados demonstram uma sequência evolutiva para ambos os aspectos, sendo que a prática das regras foi concebida como evoluindo em quatro estágios, enquanto que, para a consciência das regras, são propostos três estágios. Comecemos pela prática das regras.

Inicialmente (até os três anos aproximadamente) a criança pratica a regra de forma regular e individual, como um simples hábito motor. Posteriormente, entre 04 a 
06 anos, ocorre o jogo egocêntrico, no qual, embora haja uma tentativa de imitar as regras dos maiores, não há uma preocupação em codificá-las e cada um acaba jogando por si próprio da maneira que entende estar correto. A partir dos sete anos já é possível perceber uma tendência geral em unificar as regras e colocá-las como comuns a todos; todavia, as informações são imprecisas e contraditórias. É somente por volta dos 11 e 12 anos que as partidas começarão a ser regulamentadas por um código reconhecido mutuamente por todos.

Para a consciência das regras encontraremos transformações semelhantes. No primeiro estágio a regra, por ser puramente motora, não é encarada como realidade obrigatória, não havendo, portanto, uma consciência propriamente dita a respeito dela. O segundo estágio corresponde ao segundo e início do terceiro estágios relativos à prática; nele as regras são consideradas sagradas, imutáveis e provenientes de autoridades superiores, não sendo passíveis de modificações. Finalmente, no terceiro e último estágio (correspondente ao final do terceiro e o quarto estágio da prática das regras), já é possível perceber os efeitos da cooperação que leva os sujeitos a considerarem o consentimento mútuo e a lealdade para com o grupo como princípios norteadores de seu entendimento sobre a funcionalidade e obrigatoriedade das regras.

Com essa pesquisa Piaget demonstrou como o jogo muscular e egocêntrico torna-se social, defendendo-o como espaço de discussão e reciprocidade, no qual os indivíduos, considerando-se como iguais, poderão controlar-se mutuamente e atingir, assim, o estado cooperativo, condição primeira para o desenvolvimento do juízo moral autônomo.

A partir do exercício cooperativo as sanções, por exemplo, deixam de ser orientadas por mera punição para incluírem a reciprocidade, e a noção de justiça deixa de ser pautada na ideia de sanção (justiça retributiva) e passa a ser considerada pela via 
da equidade (justiça distributiva). É também com base na cooperação que as crianças passarão a defender a igualdade em face da autoridade ou a intencionalidade dos atos frente às consequências materiais dos mesmos (PIAGET, 1932/1994). No campo cognitivo, será ela também a responsável por modificar as atitudes egocêntricas iniciais, permitindo a inserção da criança num sistema de reciprocidade lógica e interpessoal isto é, de cooperação. Segundo Piaget (1966/1999),

De maneira geral, as formas intelectuais e sociais do egocentrismo são apenas uma [...] e as duas desaparecem em função de um só e mesmo fator: a coordenação gradual das ações, [advinda] da cooperação interindividual ou sistema das operações efetuadas em comum. (p.88)

Vemos com isso que o deslocamento da postura egocêntrica para a capacidade de coordenar diferentes pontos de vista é condição inerente ao exercício cooperativo e, consequentemente, ao desenvolvimento do juízo moral infantil, tema este de extrema importância a nossa tese e sobre o qual discorreremos a seguir, ainda que resumidamente.

Ao pensar sobre a moralidade, Piaget (1932/1994) nos apresenta belíssima análise sobre as concepções infantis de temas como a justiça, a responsabilidade e a igualdade. Não cansa de advertir seu leitor, todavia, que os dados apresentados referemse a um formato digamos suposto, porém empírico, da moral infantil. Empírico, posto que pautado em pesquisas e não somente em prerrogativas filosóficas, e suposto porque investigado a partir dos juízos emitidos pelas crianças não necessariamente confirmados por suas ações.

Pois bem, de todo o compêndio de dados e teorizações apresentado por Piaget na referida obra interessa-nos, em especial e em primeiro plano, a descrição e defesa do método utilizado na pesquisa, que consistia, a saber, na exposição de pares de dilemas morais hipotéticos no formato de estórias, sobre os quais a criança precisaria se posicionar, sempre, é claro, justificando suas respostas. Tais estórias tratavam de 
diversos temas morais como já expusemos acima, sendo que para nossa pesquisa ${ }^{4}$ selecionamos a responsabilidade por atos danosos, a justiça (analisada sobre a via da igualdade e da sanção) e a mentira.

Em todos os temas abordados, Piaget (1932/1994) discute os juízos heterônomos (advindos das relações de coação e respeito unilateral conforme discutidos anteriormente) em contraposição a juízos concebidos por meio da cooperação e do respeito mútuo, portanto, ligados à autonomia. Expõe, por exemplo, que a criança avaliará a responsabilidade por atos danosos, inicialmente, tomando em conta o resultado do dano, para só depois considerar a intencionalidade. Assim, uma criança que quebra dez copos sem querer é tida como mais culpada do que a que quebrou somente um prato, mas por motivos ilícitos. O mesmo acontece com a mentira, que é considerada tanto mais grave, quanto mais distorcer a realidade, colocando-se a intenção de enganar em segundo plano. Neste caso, para a criança heterônoma é mais mentiroso dizer que viu um cachorro do tamanho de uma vaca, do que dizer à mãe que tirou notas boas sem ter sido sequer avaliado pela professora. Piaget (ibid.) denomina o primeiro tipo de concepção, cujo conteúdo se liga mais a quantidade do dano ou a distorção da realidade, de responsabilidade objetiva, enquanto que a forma de responsabilidade concebida com base na intencionalidade é por ele denominada de responsabilidade subjetiva.

Para a justiça procedeu de forma semelhante, avaliando, por uma de suas estórias, se a criança acha justo dar pedaços maiores de bolos ao filho mais obediente, concebendo-a pela via da retribuição, ou se acha mais justo todos receberem bolos de mesmo tamanho, independentemente das condições dadas, fazendo prevalecer a

\footnotetext{
${ }^{4}$ Tais conteúdos compõe nosso roteiro de entrevista, conforme será detalhado na parte do Método.
} 
igualdade. Trata-se, portanto, de contrapor uma forma de justiça dita retributiva a uma forma superior de justiça, tida como distributiva.

A sanção esta também atrelada à questão da justiça e neste ponto Piaget (ibid.) decide avaliar o quanto ela se faz por meio da expiação ou por meio da reciprocidade. Assim, após solicitar que a criança estipule, ela própria, um castigo para o sujeito da estória, elenca três formas de sanção, que variam segundo o grau de expiação ou reciprocidade considerado, para que ela escolha a mais justa.

Infelizmente Piaget retoma muito pouco a questão da moral ao longo de sua obra, ficando este conjunto de pesquisas como o único exemplar de uma abordagem direta e específica do tema. Contudo, embora singular, o material apresenta uma riqueza de articulações e conceituações em muito desconsiderada por nossa breve exposição.

É certo que as considerações teóricas apresentadas, resumidamente, até então, embasam, além deste, muitos outros trabalhos científicos, contribuindo assim para a produção de um rico arsenal de pesquisas na área de Psicologia do Desenvolvimento. Julga-se pertinente agora a apresentação de pelo menos uma pequena parte deste arsenal. 


\section{4- O CONTEXTO DE PESQUISAS SOBRE JOGOS E MORALIDADE: UMA BREVE REVISÃO}

Por conta da já afirmada amplitude e diversidade do campo de pesquisa de ambas as temáticas aqui tratadas, delimitaremos nosso foco para os estudos concernentes à Psicologia e concentraremos nossa descrição nos centros de pesquisa onde se encontra maior produção científica relacionada a cada tema abordado, preferencialmente dentro de uma perspectiva piagetiana e, fortuitamente, circunscrita ao contexto brasileiro ${ }^{5}$.

Começando pelo tema jogos de regras tomaremos como base algumas revisões já realizadas (ROSSETTI e SOUZA, 2005; ALVES, 2006; ROSSETTI e RIBEIRO, 2009) nas quais além de apropriada amplitude, cobrindo quase a totalidade dos trabalhos produzidos no período considerado ${ }^{6}$, encontramos uma excelente sistematização dos temas abordados. Tais revisões apontam grande volume de trabalhos realizados no Instituto de Psicologia da Universidade de São Paulo, na Faculdade de Educação da Universidade Estadual de Campinas e no Programa de Pós-Graduação em Psicologia da Universidade Federal do Espírito Santo. Inicialmente sintetizaremos os principais temas investigados nestes centros para em seguida detalharmos os trabalhos cujas proposições se interligam a nossos objetivos.

Somados os três levantamentos bibliográficos supracitados, têm-se cerca de 110 trabalhos analisados (em sua maioria dissertações de mestrado de natureza empírica) e sistematizados segundo informações tais como, enfoque metodológico, jogos utilizados, aspectos investigados, faixa etária e segmentos escolares estudados. Dentre tais informações chamou-nos atenção a pouca incidência de investigações sobre aspectos morais ou até mesmo sociais e a menor frequência de pesquisas com crianças em idade pré-escolar. Ambos serão abordados novamente adiante.

\footnotetext{
${ }^{5}$ Encontramos somente dois trabalhos internacionais que abordavam o jogo atrelado a aspectos morais.

${ }^{6}$ Em sua maioria estudos piagetianos, publicados de 1980 a 2008.
} 
De maneira geral, percebe-se nas produções dos referidos centros uma preocupação em abordar a influência do jogo de regras sobre o desenvolvimento infantil em seus diferentes aspectos, com nítida primazia do fator cognitivo. Neste sentido, a produção de trabalhos varia, entre outros temas, da investigação de noções e conhecimentos específicos até a abordagem de processos de pensamento e construção cognitiva. Neste último caso enquadram-se, por exemplo, os trabalhos de Rossetti (1996), Ortega et al (2000) e Von Zuben (2003) que usam, respectivamente, os jogos Cara a cara, Mastergoal e Traverse para abordar de diferentes formas a questão do pensamento dialético, ou os estudos de Magalhães (1999) que com o jogo Cara a cara investigou o processo de construção da significação e Santos (2007) que usou o Quoridor para analisar o processo de tomada de consciência; temos ainda as pesquisas de Piantavini (1999) e Bogatshov (2001) sobre a evolução dos possíveis, de Silveira (2004) sobre processos inferenciais e de Palhares (2003) sobre o raciocínio infantil.

Já entre os trabalhos que privilegiam a investigação de noções e conhecimentos específicos, destacam-se os que abordam conteúdos lógicos e aritméticos como os de Grando (1995 e 2000), Guimarães (1998 e 2004), Pauleto (2001) e Bariccatti (2003). A primeira autora investigou o jogo como instrumento para o ensino de habilidades matemáticas gerais, a segunda focalizou as estruturas multiplicativas, enquanto os dois últimos concentraram-se nas noções de adição e subtração. Também presentes nesta categoria estão os estudos sobre as noções operatórias, entre elas a de conservação (COSTA, 1991) e a de classificação (DELL'AGLI, 2002), além de investigações sobre as categorias de compreensão do real, a saber, objeto, tempo, espaço e causalidade (CAMPOS, 1993; ZAIA, 1996).

Há ainda aqueles que salientam o papel psicopedagógico dos jogos de regras, definindo-os como instrumentos que propiciam a facilitação da aprendizagem, a 
elaboração de estratégias e a superação de erros, permitindo re-equilibrações construtivas para o sistema mental (MACEDO, 1995; MACEDO, PETTY e PASSOS, 1997, 2000 e 2005; PETTY e PASSOS, 1996).

A predominância de estudos direcionados aos aspectos cognitivos de forma alguma elimina a relevância de trabalhos em que os jogos de regras aparecem vinculados a outros aspectos do desenvolvimento. Tal fato pode ser exemplificado pelos trabalhos de Queiroz (2000), Ribeiro (2001) e Oliveira (2005), nos quais encontramos o jogo de regra vinculado a aspectos afetivos e/ou sociais. O primeiro autor investiga os tipos de erros e condutas de estudantes no jogo Senha e inclui entre seus focos de análise a vinculação destes fatores com manifestações afetivas, as quais, conclui o autor, sustentariam desequilíbrios muitas vezes não reconhecidos pelo sujeito. Em Ribeiro (2001) é possível encontrar a descrição de 12 categorias de condutas afetivas formuladas a partir do Jogo das Boas Perguntas, as quais constituem excelente referência para aqueles interessados na interlocução da prática do jogo com aspectos do comportamento e/ou desenvolvimento infantil. Todas as condutas identificadas pela autora são pertinentes a nossa análise sobre a relação da criança com a regra, em especial as díades: “concentração / dispersão", "flexibilidade / rigidez" e "cooperação / oposição". Oliveira (2005) correlacionou condutas de escolares no jogo Xadrez Simplificado com a coordenação de perspectiva espacial e a tomada de perspectiva social. Em suas descrições a respeito desta última, identifica tipos de comportamentos adotados no jogo condizentes com cada um de seus níveis, o que se torna igualmente importante para nossa análise.

Após apanhado geral da abrangência de temas contidos nos estudos levantados, passa-se ao detalhamento daqueles mais próximos aos assuntos em pauta neste trabalho. Primeiramente, daremos destaque a algumas pesquisas que buscam enfocar a interação 
social no contexto de jogo seja de forma isolada ou conjuntamente com fatores cognitivos. Em seguida, discutiremos os trabalhos que abordam mais nitidamente a questão da regra.

No primeiro grupo temos o estudo de Cavalcante (2006) que analisou, por meio do jogo "Matix", as formas de interação social de crianças em situações de competição e não-competição. Nesta última ao invés de jogarem uma contra a outra, as duas crianças resolviam juntas uma situação-problema. Foram definidas sete categorias de interação específicas para o contexto de jogo de regras que apresentaram variações de acordo com situação apresentada. No caso de competição foi mais frequente a "execução isolada" seguida da "cooperação". Na situação de não-competição, além de aparecerem dois novos tipos de interação, foi igualmente prevalente a "execução isolada", sendo que não foram registrados episódios de cooperação. Verificou-se, assim, que mudanças nos modos de apresentação da situação-problema acarretavam variações no funcionamento cognitivo dos participantes e, consequentemente, nas formas de organização de suas trocas sociocognitivas, o que vem ao encontro de algumas de nossas premissas.

Também integram este grupo os trabalhos de Teixeira (1997) e Brenelli (1986). A primeira autora pesquisou a interação de crianças pré-escolares em atividades de jogo, desenho e pintura. As situações de interação foram configuradas por meio de regras ou características do material. Seus resultados demonstram três níveis de condutas classificadas como precursoras da cooperação. Além de fornecer subsídios para a categorização de atitudes sociais em crianças pequenas, o que por si só já é válido para nossos propósitos, o trabalho em questão ao avaliar tais atitudes fazendo uso de nuances contextuais, se mostra importante em termos metodológicos. 
O segundo trabalho também nos interessa, em especial, por conta de seu enfoque procedimental. Nele foi avaliado comparativamente o desempenho de crianças no jogo Quips em situações que variavam segundo três critérios: jogo proposto pelo experimentador / jogo proposto pelo sujeito; contexto individual /contexto grupal; interação entre sujeitos do mesmo nível operatório quanto à noção de conservação / interação entre sujeitos de diferentes níveis. Buscou-se investigar por meio de tais situações a influência da idade, do nível operatório e da configuração social colocada, sendo que somente as duas primeiras obtiveram significância estatística. Todavia, é salientado o aprimoramento dos sujeitos da situação grupal que interagiram com crianças mais velhas e de maior nível operatório, defendendo-se o uso do jogo como espaço para o exercício de operação e cooperação. Discute-se ainda operações que estão subjacentes às regras do jogo, ao propô-las às crianças ou pedir-lhes que as elaborem, designando índices avaliativos de sua formulação e utilização (BRENELLI, 1986).

A regra do jogo é também discutida por Pontes e Galvão (1997), que utilizaram o jogo de peteca (bola de gude) para avaliar a habilidade de crianças de diferentes idades no manejo das regras (das mais gerais para as mais especificas). Observou-se que a aprendizagem das regras mais complexas ocorre a partir das trocas que os jogadores realizam entre si, evidenciando o papel desempenhado pelos colegas no crescimento do domínio das regras. Sugere-se, enfim, que a interação social no jogo propiciaria um uso mais circunstancial da regra e o desenvolvimento de comportamentos em conformidade com ela.

Têm-se, ainda, algumas pesquisas que, embora não trate especificamente da regra, a insere dentre os itens a analisar. De início temos os trabalhos de Melo (1993) e Carracedo (1998), ambos realizados no âmbito das aulas de Educação Física. A primeira autora, após observação das aulas e realização de entrevistas com crianças de 
07 a 11 anos, pertencentes às primeiras séries do ensino fundamental, buscou compreender, entre outras questões, as formas de organização do jogo quando proposto pelo professor ou quando realizado espontaneamente pelas crianças no que diz respeito à definição e consideração das regras. São analisadas, por exemplo, a formação de equipes ou a forma de proposição da regra nas duas situações, sendo que na primeira prevalece a divisão por sexo e o simples anúncio das regras, enquanto que na segunda há estratégias coletivas de escolha e tentativas de acordo. A partir do levantamento das principais atitudes que caracterizam as relações sociais presentes nas duas situações, traça um comparativo entre elas e debate alguns pontos importantes para atuação do professor no sentido de flexibilizar o caráter técnico-desportivo do uso jogo nas aulas de Educação Física em prol de objetivos voltados a promoção da cooperação.

Já no texto de Carracedo (1998), a análise recai sobre um jogo específico denominado Carimbador (semelhante ao Pega-pega). Seu objetivo foi investigar diferenças e similitudes entre três grupos de crianças de 4-5, 6-7 e 12-13 anos, respectivamente, quanto à consideração das regras do jogo e os esquemas de resolução de problemas. Foi observado maior compartilhamento de decisões e exigências normativas entre as crianças mais velhas, fato este que, ressalta a autora, está em conformidade com hipóteses fundamentadas no construtivismo de Piaget, dentre as quais se insere as aqui apresentadas.

Finalizando este grupo cita-se pesquisa realizada por Alves e Santos (2000) que utilizaram como critério para avaliar o desempenho de pré-escolares jogando diferentes modalidades de dominó o seguimento das regras e domínio dos conceitos nelas implícitos. Interessante notar que tais critérios foram avaliados por meio dos comportamentos de erro ou ajuda, constituindo-os como possíveis indicadores do uso da regra. Dentre seus resultados, destaca-se a ocorrência de uma coordenação progressiva 
entre o pré-determinado (regras) e o estratégico (objetivos), isto é, a capacidade de coordenar ações simultaneamente no passado, presente e futuro.

Conforme já exposto, em nossa proposta de pesquisa o jogo de regras aparece articulado com aspectos do desenvolvimento moral infantil. Por conta disto, mencionaremos, a partir de agora, algumas facetas da produção científica acerca da psicologia da moralidade, ainda que de forma mais restrita.

Procedendo de forma semelhante a anterior, tomaremos por base revisão realizada por Vale (2006), na qual estão indicados como centros de referência na área a Universidade Federal da Paraíba, a Universidade Federal do Rio Grande do Sul e novamente a Universidade de São Paulo.

No primeiro dos centros acadêmicos citados, são proeminentes os trabalhos de Cleonice Camino e seu grupo que estuda o desenvolvimento moral ligado a temas como papel sexual (BIAGGIO, CAMINO e VIKAN, 2005), prática materna de controle (CAMINO, C., CAMINO, L. e MORAES, 2003) e compreensão de valores e deveres em crianças e adolescentes (CAMINO et al, 2005).

O segundo centro conta com extensa produção de Ângela Biaggio, a qual deixou um verdadeiro legado cujo conteúdo reúne, principalmente, pesquisas sobre a aplicabilidade de métodos kohlberguianos para a realidade brasileira (BIAGGIO, 1997, 1999, 2002; BIAGGIO et al., 1999), e de Silvia Koller que embora realize estudos mais focados no desenvolvimento geral de crianças em situação de risco social, não deixou de abordar em alguns deles o nível de julgamento moral, o desenvolvimento da moralidade pró-social e a expressão de emoções morais nesta população (KOLLER, 1989; BERNADES e KOLLER,2003; KOLLER e PALUDO, 2008).

Por fim, no terceiro centro, encontra-se rica produção científica acerca do desenvolvimento moral infantil relacionado a diferentes virtudes como polidez, 
vergonha, generosidade, sendo ela, em sua maioria, realizada por La Taille (2000, 2001a, 2001b, 2002, 2006).

Em revisão feita por Alencar (2005) ${ }^{7}$ são identificados quatro grandes campos temáticos de estudos na área: as relações entre o juízo moral e a ação moral; a questão do relativismo versus universalismo; as relações entre cognição, afetividade e/ou moralidade e, por fim, a definição sobre o que é moral. São apontados também alguns enfoques norteadores como, por exemplo, a ética do cuidado e a ética da justiça em Gilligan (1992), o domínio pró-social em Eisenberg (1983), a personalidade moral em Puig (1998) e o sentimento de vergonha como um regulador moral em Araújo (1998, 1999). ${ }^{8}$

Observa-se também um grande número de pesquisas sobre desenvolvimento moral voltadas para a identificação de suas influências diversas, bem como aquelas que buscam estabelecer relações entre desenvolvimento moral e fatores como condição socioeconômica, escolaridade, práticas educativas parentais, gênero, grau de empatia, entre outras. Um exemplo é o estudo de Moretto (2003) que estudou o conceito de moral evidenciado por adolescentes e detectou variação de acordo com a faixa etária e nível de escolaridade, mas descartou a influência de condições socioeconômicas. Já Soares (1996) e Batista (1997) encontram correlações positivas entre moralidade e empatia, sendo que a segunda verificou também interferências de gênero nestes quesitos. O julgamento moral foi estudado ainda em associação com delinquência juvenil e ausência paterna por Bzuneck (1979) e em relação à identificação com o professor por Dallegrave (1999), ambos verificaram correspondências, ainda que em parte, entre os fatores investigados.

\footnotetext{
${ }^{7}$ A autora utilizou a base dados PSYCLIT e pesquisou o período de 1972 a 2001.

${ }^{8}$ Todos citados por Alencar (2005), portanto, não listados nas referências deste texto.
} 
Um ramo de pesquisas também proeminente na área considera aspectos sociais no estudo da moralidade e, por isso, se faz mais interessante a nossa discussão. É o caso do estudo de Dessandre (2004) que buscou analisar o papel do conflito como estratégia para a construção da personalidade moral, e o de Tichy et al (2010), que examinou os efeitos da controvérsia cognitiva em comparação com a aprendizagem individual no desenvolvimento de habilidades éticas e atitudes sociais, e constatou que os participantes da primeira obtiveram significativas melhoras nestes aspectos em relação aos da segunda. Outro estudo digno de nota é o de Estrazulas (2004) que, ao investigar as trocas de ações e operações de pensamento, interindividuais e coletivas entre os participantes de uma rede social, inclui entre suas categorias de análise as possíveis influências do self-government e do trabalho em grupo na aprendizagem das noções de solidariedade e justiça. Tanto o conflito, a controvérsia cognitiva, como o selfgovernment e as trocas interindividuais são temas passiveis de serem debatidos no contexto de jogo.

Aliás, existem alguns trabalhos que fazem uso do jogo para a discussão de conteúdos morais. Como no estudo de Gummerum et al (2010), cujo objetivo foi examinar o papel das emoções morais no desenvolvimento da reciprocidade e altruísmo, utilizando o Jogo do Ditador, ou no de Frias (2010), onde foram avaliadas as possibilidades do RPG (ou Jogo das Representação) enquanto recurso favorável ao desencadeamento de atividades relacionadas à cooperação e à capacidade de negociação, entendidas como próprias do desenvolvimento da moral autônoma. Conclui este autor que "o RPG é um recurso capaz de integrar iniciativas mais abrangentes em favor da construção da autonomia, mas que por si só, como todo recurso, não é suficiente para garantir sua ocorrência”. (ibid, p. 96) 
O trabalho de Pessotti (2010) mostra-se igualmente relevante ao tema de nossa pesquisa, pois investiga, em uma perspectiva psicogenética, a trapaça no jogo Cara a cara, relacionada ao juízo moral e à ação, respectivamente. Para tanto, em sua metodologia, utiliza três situações, uma hipotética na qual se tem a trapaça de forma narrada, uma real onde se busca a observação do ato de trapacear durante uma partida do jogo (nela a pesquisadora ausenta-se da sala por alguns instantes) e uma terceira que consiste em uma pequena entrevista com a criança sobre o acontecido (ter ou não trapaceado). Seus resultados demonstram uma variedade de concepções e comportamentos emitidos pelas crianças sobre a trapaça e constituem boa referência para a investigação de temas morais no contexto de jogo.

No amplo espectro de aspectos da moralidade que são pesquisados atualmente, estão interligadas a nosso estudo investigações que consideram, direta ou indiretamente, princípios normativos. Tal enfoque pôde ser encontrado na pesquisa de Calo (2004), na qual são discriminadas três dimensões da moralidade: valoração da norma, concepção de responsabilidade e comportamento moral, vinculadas, respectivamente, à obediência a autoridade, consideração da intenção nos atos e relação com pares, fatores estes extremamente próximos de alguns dos temas tratados em nosso próprio estudo, daí a relevância de entender melhor sua natureza e aplicação.

A regra em seu sentido moral foi também considerada por Martins (1995) e Dias (1990 e 1992). Em seus respectivos textos os autores tratam da relação entre moralidade e convenção. Martins (1995) examinou as respostas de crianças pequenas a eventos morais e sócio-convencionais. Foi avaliado, entre outros fatores, o julgamento da gravidade, contingência e relatividade da regra. Os resultados não indicaram clara distinção entre as respostas a eventos morais e sócio-convencionais. Constatação semelhante é apresenta por Dias (1990 e 1992), que pesquisou a compreensão infantil 
de conceitos sociais e morais em três desenhos amostrais distintos (crianças brasileiras e inglesas de NSE médio, e crianças brasileiras de orfanatos). Foram avaliadas as discriminações infantis entre regras morais e convencionais em termos de grau de ofensa e de consequências (arbitrárias / intrínsecas) e tipos de violação, por meio de brincadeiras de faz-de-conta e problemas silogísticos. De maneira geral os resultados indicaram que, em nenhuma das três amostras estudadas, houve distinção entre estes dois domínios.

Ainda tratam, de certa forma, da relação entre conteúdos morais e convencionais os estudos de Menin (1985) e Sales (2000), nos quais os primeiros são analisados em conjunção às normas escolares.O segundo estudo estabelece um paralelo entre o uso dos princípios de justiça distributiva e os conceitos de certo e errado em situações do cotidiano escolar. Dentre suas constatações, destaca-se a prevalência da heteronomia no julgamento das normas escolares, a qual é explicada pelo fato da escola muitas vezes não se organizar enquanto comunidade justa: suas regras geralmente são ditadas pelo adulto, abstendo-se da construção conjunta e fundando-se em relações de coação pautadas no respeito unilateral.

Menin (1985) compartilha desta visão ao discutir, com base no estudo da evolução do respeito às regras escolares pelos alunos, como a escola, ao usar da autoridade para impor regulamentos, direcionar ações e limitar as trocas sociais, acaba por favorecer o predomínio da coação e reforçar a heteronomia, dificultando o estabelecimento de um ambiente cooperativo, regulado por ajustamentos recíprocos e atuações coletivamente motivadas. A autora coloca como questão central do seu trabalho o papel da escola na formação moral de seus alunos, e conclui que os princípios de reciprocidade, igualdade ou justiça entre os indivíduos, tão importantes a esta formação, são ainda pouco considerados em seu cotidiano. 
Finalizada a exposição de alguns trabalhos que se aproximam da temática aqui proposta, cabe agora apresentar o percurso metodológico percorrido, tendo sido este destinado ao levantamento de dados significativos que possam contribuir para a obtenção de um arsenal teórico e empírico cada vez mais rico e diversificado. Considera-se que, ainda que de forma incompleta, foi possível delimitar nosso estudo frente ao panorama científico atual, especialmente, em meio ao escopo de pesquisas empíricas. Muitos dos trabalhos levantados são de extrema relevância para nossa pesquisa, pois servem de referência para muitas das análises aqui empreendidas. 


\section{5- DELIMITAÇÃO DO PROBLEMA E JUSTIFICATIVA}

Esta pesquisa busca seu embasamento na seguinte premissa: situações que envolvem jogos de regras ao possibilitarem a interação entre iguais podem favorecer o exercício cooperativo e, deste modo, colaborar com o desenvolvimento do juízo moral na criança. Além disso, sendo a consciência e a prática das regras fatores relevantes para a compreensão do desenvolvimento moral, os diferentes contextos que envolvem o jogar com regras, podem revelar-se espaços privilegiados para o estudo da moralidade infantil. Desta forma, este trabalho parte da interlocução entre jogo de regras e desenvolvimento moral tão bem explicitada por Piaget em seu texto de 1932, no qual encontramos uma análise detalhada da gênese da regra, para defender e propor o estudo das diferentes manifestações deste processo em recortes situacionais distintos.

Busca-se, assim, discutir o desenvolvimento moral infantil, a partir do estudo da relação da criança com a regra em diferentes contextos, utilizando-se para tanto os jogos de regras em si (situações concretas) e estórias dilemas sobre jogos (situações hipotéticas). Por se pautarem em preceitos construtivistas e interacionistas as formulações aqui empreendidas consideram que a aquisição de qualquer conteúdo pelo sujeito se dá a partir da elaboração ativa das informações advindas do meio, ou seja, que a gênese de qualquer estrutura provém de movimentos de troca, onde elementos do interior e do exterior atuam de forma complementar. Com a regra não seria diferente. Piaget (1932/1994), conforme já exposto, demonstrou como se dá sua construção. O que se pretende aqui é exatamente analisar se e como alguns elementos do exterior desencadeiam perturbações em elementos do interior no que diz respeito à regra, mais explicitamente, quais tipos de regulações e compensações são postos em funcionamento por sujeitos, em um período de transição do desenvolvimento moral, frente a certos arranjos situacionais. 
Sendo assim, a presente pesquisa tem como objetivo geral investigar diferentes formas de interação da criança com a regra em situações concretas e hipotéticas de jogo, destacando suas possíveis interfaces com o desenvolvimento moral infantil, segundo o referencial psicogenético piagetiano.

Dentro desta proposta encontram-se os seguintes objetivos específicos:

(1) Evidenciar alguns comportamentos e manifestações das crianças durante as diferentes situações experimentais propostas, principalmente no que diz respeito à compreensão e uso das regras, trocas cooperativas, consideração da perspectiva alheia, interajuda, realização de acordos consensuais, resolução de conflitos, tomadas de decisão e emissão de julgamentos;

(2) Proceder a uma análise comparativa das formas de interação do sujeito com a regra nas diferentes situações experimentais propostas;

(3) Identificar as potencialidades, possíveis influências e peculiaridades de cada contexto proposto no que diz respeito ao uso e compreensão das regras pelas crianças;

(4) Avaliar os juízos dos sujeitos com relação às regras morais, tomando como referência as noções de justiça (distributiva ou retributiva), de sanção (expiatória ou recíproca) e de responsabilidade (objetiva ou subjetiva), averiguando se tais juízos morais são aplicados ao domínio do jogo e como se dá sua aplicação;

Tais objetivos decorrem da hipótese de que as nuances de contextos exercerão influências no modo das crianças lidarem com as regras, sendo essas nuances com relação à natureza da tarefa (concreta no jogo e hipotética na entrevista) e proposição das regras (pré-determinadas ou acordadas). Considera-se ainda que tais influências 
terão diferentes repercussões com relação à configuração da situação (individual, coletiva, com adulto ou entre iguais).

Com base na teoria de Piaget, espera-se já encontrar um uso mais autônomo da regra na situação coletiva de regras acordadas, isto porque a regra, por conter um caráter social, está atrelada a maiores possibilidades de efetuação de trocas interindividuais. Além disso, defende-se a ideia do jogo de regras como espaço propício ao exercício cooperativo, acreditando-se com isso na possibilidade de uma maior manifestação de posturas autônomas em contextos com maior abertura a reciprocidade.

$\mathrm{Na}$ verdade, por se tratar de um estudo descritivo-exploratório, as hipóteses acima descritas encontram-se atreladas a uma série de perguntas mais do que necessariamente a expectativas de confirmações. Desta forma, acredita-se que elas estariam melhor representadas pelas questões abaixo:

- A criança se relaciona com a regra no contexto de jogo da mesma forma que o faz em outros contextos regrados?

- Mudar a situação altera a forma da criança se relacionar com a regra? Quais tipos de mudanças seriam desencadeados por tais nuances contextuais?

- Até que ponto a forma de proposição da regra interfere no modo da criança lidar com ela?

- Em quais configurações sociais a regra será usada mais autonomamente?

- As crianças que fazem uso mais autônomo da regra são aquelas com juízo morais também mais autônomos?

- E finalmente, os sujeitos se comportam com relação às regras do jogo de forma semelhante à regra moral? Isto é, a concepção da criança referente à regra do jogo corresponde aos juízos por elas emitidos a respeito da regra moral? 
Tais propósitos representam, assim, uma preocupação em se debater a relação da criança com a regra como aspecto determinante de seu desenvolvimento moral e do jogar como situação propícia ao estudo desta relação.

Além de poder fornecer valiosas oportunidades de experiências com regras, o jogar reúne uma série de condições relacionadas a conteúdos morais como, por exemplo, a possibilidade de trapacear ou não, o respeito ao adversário, o cumprimento da palavra empenhada, a decisão em alertar ou não o rival sobre seu erro, entre outros.

Ademais, a abordagem da moralidade numa perspectiva piagetiana, enfatiza fundamentalmente a maneira como o indivíduo lida com as regras, isto é, se por meio da obediência heterônoma ou da consciência autônoma, sendo esta última propiciada pela troca cooperativa, a qual pode vir a ser favorecida pelo jogar com regras. Vale lembrar que o benefício inerente à prática dos jogos de regras é exatamente possibilitar trocas interindividuais igualitárias, interlocuções de ideias e argumentações consensuais que, baseadas na reciprocidade, favorecem a cooperação.

Outro aspecto relevante da presente pesquisa pode ser encontrado em sua metodologia que, ao estabelecer a utilização de jogos de regras como proposta de abordagem do desenvolvimento moral, amplia o escopo de pesquisas nesta área, que como vimos, encontra-se em grande parte focado em processos cognitivos ou na aprendizagem de conteúdos. Busca-se com isso contribuir com reflexões acerca do jogar como estratégia para o processo de formação moral das crianças.

Diante disto, cabe ainda salientar a importância de trabalhos que visem compreender as práticas e concepções inerentes ao desenvolvimento infantil, como parâmetros para se pensar ações educativas destinadas à formação de indivíduos participativos, reflexivos e autônomos. 


\section{6- MÉTODO}

\section{1- Participantes}

Participaram da pesquisa 64 crianças com idades entre 07 e 08 anos, divididas em 14 grupos com em média quatro componentes cada (dois meninos e duas meninas). Todas alunas de três escolas particulares pré-selecionadas. ${ }^{9}$

A faixa etária em questão foi determinada como forma de se investigar etapas de transição do desenvolvimento moral, sendo que correspondem, segundo a teoria piagetiana, ao período em que se inicia a construção de juízos morais mais autônomos.

A escolha por formar grupos partiu da própria peculiaridade do fenômeno investigado (regras), que uma vez atrelado a processos de regulação social requer sua abordagem em contextos coletivos.

\section{2- Instrumentos e procedimentos}

Cada criança passou por quatro diferentes contextos de contato com regras, sendo três concretos, envolvendo o uso jogos de regras, e um hipotético, composto por estórias-dilemas, conforme listado abaixo:

1- Jogo em grupo com regras pré-determinadas (situação fechada - jogo Ludo);

2- Jogo em grupo com regras sugeridas e passíveis de modificação (situação intermediária - jogo Uno);

3- Jogo em grupo com regras acordadas (situação aberta - protocolo próprio);

4- Entrevista clínica individual (situação hipotética - estórias-dilema).

\footnotetext{
${ }^{9}$ A escolha por escolas particulares e por formar grupos mistos se deu por mera conveniência, não sendo consideradas variáveis para a pesquisa.
} 
No primeiro contexto, denominado situação fechada, as crianças jogaram conforme regras prescritas pela experimentadora. No segundo contexto o grupo recebeu sugestões de regras, podendo discuti-las (situação intermediária). Já no terceiro, denominado situação aberta, as regras foram determinadas pelos próprios jogadores a partir de mediações problematizadoras. Para o primeiro contexto foi utilizado o jogo Ludo (anexo 03), escolhido com base em pré-testes realizados no estudo piloto, destacando-se por apresentar um conjunto diversificado de regras e por ter suscitado maior interesse das crianças. No contexto dois as crianças jogaram o jogo Uno (anexo 04), interessante aos nossos objetivos por ser um instrumento versátil, com variado repertório de uso e amplas possibilidades de estruturação em termos de regras. $\mathrm{Na}$ situação aberta (contexto três) foi utilizado um conjunto de cartas com gravuras diversas (ações, objetos, pessoas, animais, etc) produzido a partir do material Conte um conto (MACEDO, PETTY e PASSOS, 2005), um dado, pinos e um tabuleiro com percurso numerado. Foi solicitado aos sujeitos que inventassem um jogo utilizando os itens que julgassem necessários. A atividade foi conduzida com base no protocolo em anexo (anexo 01), elaborado a partir do trabalho de Brenelli (1986) e de situações vivenciadas no estudo piloto.

Foram realizadas sessões semanais, com duração aproximada de $1 \mathrm{~h}$ para cada modalidade de contexto descrita, num total de três sessões para cada grupo. Estava previsto inicialmente que a situação aberta seria realizada em duas sessões, uma para elaboração do jogo e outra para realização das partidas, o que se mostrou desnecessário, pois as crianças discutiam formas de jogar e jogavam concomitantemente. Ocorreu a realização de pelo menos uma partida completa dos jogos em cada sessão. 
Para viabilização do projeto em meio à rotina escolar as sessões de jogos foram realizadas uma vez por semana, durante um turno de aula com uma turma completa ${ }^{10}$, subdividida em subgrupos de quatro a cinco crianças. Destes subgrupos três eram sempre filmados, constituindo a amostra. A necessidade de que fossem realizados todos os grupos de uma mesma turma ao mesmo tempo, exigiu a colaboração de seis auxiliares de pesquisa, sendo todas estudantes de Psicologia de uma faculdade particular que foram devidamente treinadas pela própria pesquisadora.

Assim, participaram das sessões de jogo ao todo 128 crianças, sendo que 72 foram selecionadas aleatoriamente para constituírem os grupos filmados. Ao final da coleta foram contabilizadas 59 crianças que passaram por todos os procedimentos propostos. Dos 18 grupos filmados (seis turmas, três grupos de cada), 14 tiveram os dados tabulados por completo, totalizando os 64 sujeitos da amostra, dos quais 48 fazem parte do grupo que participou de todas as etapas. As 16 crianças restantes, que possuem uma ou duas atividades pendentes, foram mantidas na amostra por integrarem a primeira parte da análise dos dados que verifica a ocorrência de indicadores por contexto.

Concluída a aplicação dos diferentes contextos de jogo, os sujeitos passaram por uma entrevista clínica contendo estórias-dilema, semelhantes às utilizadas por Piaget (1932/1994), na qual foram investigadas suas concepções relativas a quatro aspectos da moralidade, a saber: a) responsabilidade objetiva (consequência) ou subjetiva (intencionalidade) por atos danosos; b) justiça retributiva e distributiva; c) sanções (expiatórias ou recíprocas) e d) mentira. A entrevista consistiu na apresentação de quatro pares de estórias-dilemas, devidamente ilustradas, nas quais eram contrapostas situações de jogo com situações do cotidiano, no intuito mesmo de avaliar, em um plano

\footnotetext{
${ }^{10}$ A coleta ocorreu em seis turmas, sendo três da escola 01, duas da escola 02 e uma da escola 03 .
} 
hipotético, os juízos das crianças a respeito da regra nestas duas situações. Buscou-se assim com a entrevista, averiguar como a criança lida com a regra moral hipoteticamente, tanto num contexto cotidiano quanto no contexto de jogo, para posteriormente articular suas concepções com suas condutas concretas. A entrevista foi gravada e posteriormente transcrita. $\mathrm{O}$ roteiro pode ser consultado no anexo 02 .

Tanto nas sessões de jogo quanto na aplicação da entrevista clínica a pesquisadora e suas auxiliares fizeram uso de questionamentos complementares, a fim de esclarecer o significado de algumas ações e verbalizações das crianças ou verificar as razões de suas respostas. Tais perguntas são típicas do método clínico piagetiano e podem ser de exploração, justificação ou controle (DELVAL, 2002). Cabe salientar que todos os instrumentos descritos visaram exclusivamente o levantamento de dados, não consistindo em meio de intervenções e/ou tratamento de qualquer natureza para além da experimental.

\section{3- Procedimentos para análise dos dados}

Os dados foram explorados em vários sentidos e organizados de maneira descritiva a partir de tabulações e categorizações (todas as planilhas encontram-se anexadas em CD-ROM - anexo 05). A sistematização de todo o material coletado consistiu, essencialmente, em análises exploratórias centradas na busca de correspondências e interseções entre os diferentes fatores abordados sem, no entanto, estipular conclusões do tipo causa-efeito. Buscou-se com isso, evitar o estabelecimento de direções únicas e exclusivas para a análise, até mesmo porque os fatores em questão são alvos de influências diversas que escapam ao alcance da presente investigação.

Sendo assim, foram analisados, de uma maneira sistemática e comparativa, os indícios e informações levantadas em todas as etapas da pesquisa, no intuito de 
identificar formas diversas de abordagem das regras pelas crianças em cada um dos contextos estudados, buscando assim articular os diferentes tratamentos direcionados aos temas alvo da presente investigação. Por fim, vale ressaltar que, embora tenha se contado vez ou outra com quantificação dos dados, a análise foi sobremaneira qualitativa e ocorreu conforme as etapas que se seguem.

\subsection{1 - Análise dos vídeos de jogo para elaboração dos indicadores empíricos:}

Como procedimento de análise cada sessão foi assistida inicialmente duas vezes, sendo a primeira por uma das auxiliares para a transcrição da mesma e a segunda pela própria pesquisadora para revisão e marcação ou acréscimo de trechos em que ocorreram manifestações e ações interessantes ao estudo. Os textos das transcrições já revisadas foram então lidos e tabulados com base em alguns indicadores já elaborados a partir do estudo piloto e outros que foram sendo elaborados no decorrer da tarefa. Ao final desta etapa contávamos com 36 indicadores divididos em três categorias, a saber: relações com a regra, relações entre ações no jogar e relações entre pessoas.

\subsection{2 - Análise das transcrições para revisão e classificação dos indicadores:}

Com o progresso da análise percebeu-se a necessidade de uma melhor delimitação dos indicadores e sua reorganização em níveis. Assim, foi criado um protocolo com os tipos de comportamentos comumente associados a cada indicador, os quais puderam, a partir daí, ser rearranjados, redefinidos ou eliminados. O que, obrigatoriamente, implicou em uma nova análise das transcrições. O quadro abaixo mostra como ficou a nova e definitiva classificação dos indicadores e conta com uma breve descrição dos mesmos. Vale acrescentar que o agrupamento em níveis se deu de acordo com o que foi considerado mais avançado em termos do uso autônomo da regra. 


\section{CATEGORIAS / INDICADORES}

\section{RELAÇÕES COM A REGRA}

1. Não compreende / Distorce a regra (não usa de estratégia, erro recorrente).

2. Não segue a regra (age arbitrariamente de forma não regulamentada) / Tenta burlar (manipula) /Trapaceia.

3. Interpreta a regra (usa de estratégia, antecipa, planeja a jogada, prevê consequências) / Questiona e/ou discute a regra (sua legitimidade ou funcionalidade - protesta, vai contra).

4. Esquece a regra

5. Recorre à regra para acusar (questiona a jogada alheia, adverte verbalmente).

6. Recorre à regra para se defender / se justificar (ou como garantia de direito).

7. Recorre à regra para defesa alheia (ou como garantia do direito de outrem).

8. Faz valer a regra (corrige seu próprio erro, usa de honestidade).

NIVEL I - 1 e 4

NIVEL II - 2, 5 e 6

NIVEL III - 3, 7 e 8

\section{RELAÇÕES ENTRE AÇÕES NO JOGAR}

9. Opina / Muda / Interfere / Corrige jogada alheia em benefício próprio.

10. Opina / Muda / Interfere / Corrige jogada alheia em benefício do outro.

11. Opina / Muda / Interfere / Corrige jogada alheia acarretando prejuízo.

NIVEL I - 11

NIVEL II -9

NIVEL III - 10

\section{RELAÇÕES ENTRE PESSOAS}

12. Propõe algo ao grupo / Efetiva acordo / Busca consenso (resolve conflito diretamente)

13. Comemora ou torce por azar alheio / Expressa superioridade (provoca) / Demonstra insatisfação com a sorte alheia.

14. Comemora sorte alheia / Torce pelo outro.

15. Recorre ao adulto para se certificar.

16. Recorre ao adulto para se defender.

17. Recorre ao adulto para acusar (questiona jogada alheia)

18. Recorre a um colega para se certificar.

19. Recorre a um colega para se defender.

20. Recorre a um colega para acusar um terceiro.

21. Questiona o adulto em benefício próprio.

22. Questiona o adulto em benefício de outro.

NIVEL I - 13, 15, 16 e 17

NIVEL II - 18, 19 e 20

NIVEL III - 12, 14, 21 e 22

Quadro 01 - Descrição dos indicadores dos jogos por níveis 
6.3.3 - Análise conjunta dos vídeos e transcrições para tabulação e verificação dos indicadores:

Finalizada a classificação das manifestações e ações das crianças em indicadores deu-se início a tabulação da frequência de emissão dos mesmos por cada sujeito, a qual foi realizada a partir das transcrições e depois verificada diretamente nos vídeos. Este tipo de levantamento foi utilizado para classificação dos sujeitos em níveis, com a qual realizamos a análise propriamente dita, processo este organizado em três vias: relações entre indicadores; relações entre contextos e análises individuais.

As duas primeiras vias serviram para se estabelecer pontos de interferências ou influências de um indicador sobre outro, acompanhando as ocorrências casadas ou excludentes e delimitando possíveis correspondências ou relações entre eles. Assim, foi possível fazer comparações entre os contextos a partir do tipo e frequência de indicadores que apresentavam.

Com o avanço na sistematização dos dados foi possível chegar ao último tipo de análise aqui proposto, cujo conteúdo se aproxima mais diretamente dos objetivos da pesquisa por permitirem o acompanhamento individualizado dos aspectos investigados. Desta forma, buscou-se um detalhamento da ocorrência de indicadores por sujeito, que permitisse não só acompanhar o desempenho de uma mesma criança nos diferentes contextos, mas também delimitar suas atuações dentro de uma única situação.

A classificação dos sujeitos em níveis também se deu em diferentes vias, seguindo alguns critérios de cruzamento entre os dados. Obtida, então, a frequência de emissão de indicadores por cada sujeito procedeu-se com sua somatória segundo alguns índices de distribuição de peso estipulados para cada item avaliado. Tal procedimento foi realizado para o estabelecimento de níveis com base nas categorias elaboradas e segundo as situações propostas, conforme descrição a seguir: 
A- Classificação por situação concreta de jogo: estabelece os níveis dos sujeitos para cada situação (fechada, intermediária e aberta), a partir da soma das ocorrências de indicadores obtidos pelos sujeitos em cada categoria atribuindo importâncias diferenciadas para elas, segundo os seguintes critérios:

*Sendo: $\mathrm{R}$ = relações com a regra. $\mathrm{A}=$ relações entre ações no jogar. $\mathrm{P}=$ Relação entre pessoas.

- Total absoluto (T): $\mathrm{R}+\mathrm{A}+\mathrm{P}$

- $1^{\mathrm{a}}$ distribuição de pesos $(\mathrm{C} 1):(5 \times \mathrm{R})+(3 \times \mathrm{A})+(2 \times \mathrm{P})$

- $2^{\mathrm{a}}$ distribuição de pesos (C2): $(4 \times \mathrm{R})+(3 \times \mathrm{A})+(3 \times \mathrm{P})$

- $3^{\mathrm{a}}$ distribuição de pesos $(\mathrm{C} 3):(5 \times \mathrm{R})+(2 \times \mathrm{A})+(3 \times \mathrm{P})$

B- Classificação por categoria: estabelece os níveis dos sujeitos para cada categoria (regra, ações e pessoas), a partir da soma das ocorrências de indicadores obtidos pelos sujeitos em cada situação atribuindo importâncias diferenciadas para elas, segundo os seguintes critérios:

*Sendo: $\mathrm{L}=$ Ludo - situação fechada. $\mathrm{U}=\mathrm{Uno}$ - situação intermediária. $\mathrm{S}=$ Situação aberta - protocolo

- Total absoluto (T): $\mathrm{L}+\mathrm{U}+\mathrm{S}$

- $1^{\mathrm{a}}$ distribuição de pesos (C1): $(5 \times \mathrm{L})+(2,5 \times \mathrm{U})+(2,5 \times \mathrm{S})$

- $2^{\mathrm{a}}$ distribuição de pesos (C2): $(2,5 \times \mathrm{L})+(2,5 \times \mathrm{U})+(5 \times \mathrm{S})$

Tais critérios serviram de base para diferenciações entre os fenômenos investigados e auxiliaram na identificação de peculiaridades nas trajetórias dos sujeitos classificados em um mesmo nível, permitindo, inclusive, melhor definição do status dado a cada procedimento conforme os pressupostos teóricos deste estudo. Assim, foi possível estabelecer comparações de acordo com o que era mais relevante no contexto 
da pesquisa, ou seja, pode-se diferenciar, por exemplo, o desempenho de duas crianças que obtiveram NIII pelo critério de soma simples das ocorrências de indicadores (T), porém uma tendo se destacado nos indicadores da categoria relação com a regra $(R)$ e outra por conta da categoria ações no jogar (A).

\subsection{4 - Elaboração de indicadores para análise das entrevistas (contexto hipotético):}

O conteúdo das entrevistas foi tratado de forma semelhante aos demais, procedendo-se com uma primeira transcrição pelas auxiliares, uma revisão e verificação de coerência pela pesquisadora, preparação de um protocolo com os tipos de respostas encontradas e elaboração dos critérios de análise, conforme o quadro a seguir:

\section{CLASSIFICAÇÃO DE NÍVEIS ENTREVISTAS}

RESPONSABILIDADE

1 a parte (letras B e C do protocolo analisadas conjuntamente)

\begin{tabular}{|c|c|c|}
\hline Pontuação & JOGO & COTIDIANO (CASA) \\
\hline 01 & objetiva & objetiva \\
\hline 1,5 & objetiva & intermediário \\
\hline 1,5 & intermediário & objetiva \\
\hline 02 & objetiva & subjetiva \\
\hline 02 & intermediário & intermediário \\
\hline 02 & subjetiva & objetiva \\
\hline 2,5 & subjetiva & intermediário \\
\hline 2,5 & intermediário & subjetiva \\
\hline 03 & subjetiva & subjetiva \\
\hline
\end{tabular}

2a parte (letra D do protocolo)

\begin{tabular}{|l|l|}
\hline 01 & Mais errado em casa por conta da desobediência. \\
\hline 02 & Mais errado em casa por acarretar consequências ou causar danos maiores \\
\hline 03 & Mais errado em casa ou no jogo por conta da intenção. \\
\hline 04 & Igualmente errado \\
\hline
\end{tabular}

\section{JUSTIÇA}

$\underline{1 \text { a parte (letras } \mathrm{B} / \mathrm{C} \text { e } \mathrm{D} / \mathrm{E} \text { do protocolo analisadas conjuntamente) }}$

\begin{tabular}{|c|c|c|}
\hline Pontuação & JOGO & COTIDIANO (TAREFAS) \\
\hline 01 & retributiva & retributiva \\
\hline 1,5 & retributiva & intermediário \\
\hline 1,5 & intermediário & retributiva \\
\hline 02 & distributiva & retributiva \\
\hline
\end{tabular}




\begin{tabular}{|c|c|c|c|}
\hline & 02 & intermediário & intermediário \\
\hline & 02 & retributiva & distributiva \\
\hline & 2,5 & distributiva & intermediário \\
\hline & 2,5 & intermediário & distributiva \\
\hline & 03 & distributiva & distributiva \\
\hline \multicolumn{4}{|c|}{ 2a parte (letra F do protocolo) } \\
\hline 01 & \multicolumn{3}{|c|}{ Igual (ambos justos) - Não considera a igualdade em nenhum dos dois. } \\
\hline 02 & \multicolumn{3}{|c|}{$\begin{array}{l}\text { Mais justo nas tarefas por ser mais sério - Desconsidera a necessidade de igualdade no jogo, aceita a } \\
\text { desigualdade. }\end{array}$} \\
\hline 03 & \multicolumn{3}{|c|}{$\begin{array}{l}\text { Mais justo nas tarefas ou no jogo por conta do empenho, por merecimento. Mais justo no jogo por } \\
\text { ser fruto de um acordo momentâneo. - considera a necessidade de igualdade em ou no outro, tenta } \\
\text { justificar (amenizar) a desigualdade. }\end{array}$} \\
\hline 04 & \multicolumn{3}{|c|}{ Igual (ambos injustos) - considera a necessidade de igualdade nos dois casos } \\
\hline
\end{tabular}

\section{SANÇÃo}

1a parte (letras $\mathrm{B} / \mathrm{C}$ e D/E do protocolo analisadas conjuntamente)

\begin{tabular}{|c|c|c|}
\hline Pontuação & JOGO & COTIDIANO (FILA) \\
\hline 01 & expiatória & expiatória \\
\hline 1,5 & expiatória & intermediário \\
\hline 1,5 & intermediário & expiatória \\
\hline 02 & expiatória & recíproca \\
\hline 02 & intermediário & intermediário \\
\hline 02 & recíproca & expiatória \\
\hline 2,5 & intermediário & recíproca \\
\hline 2,5 & recíproca & intermediário \\
\hline 03 & recíproca & recíproca \\
\hline
\end{tabular}

\section{2․ parte (letra F do protocolo)}

\begin{tabular}{|l|l|}
\hline 01 & Mais errado na fila ou no jogo por conta da desobediência \\
\hline 02 & Mais errado na fila por acarretar consequências ou causar danos maiores \\
\hline 03 & Fila ou jogo por conta da intenção. \\
\hline 04 & Os dois fizeram errado. Daria o mesmo castigo para os dois. \\
\hline
\end{tabular}

OBS: Mais avançado quanto mais considerar o respeito ao outro em conjunto com a regra.

\section{MENTIRA}

19 parte (letras $\mathrm{A} / \mathrm{B} / \mathrm{C}$ e E/F/G do protocolo analisadas conjuntamente)

\begin{tabular}{|c|c|c|}
\hline Pontuação & JOGO $^{*}$ (queimada X leão) & COTIDIANO (desenho X cachorro) \\
\hline 01 & objetiva & objetiva \\
\hline 1,5 & objetiva & intermediário \\
\hline 1,5 & intermediário & objetiva \\
\hline 02 & objetiva & subjetiva \\
\hline 02 & intermediário & intermediário \\
\hline 02 & subjetiva & objetiva \\
\hline 2,5 & subjetiva & subjetiva \\
\hline 2,5 & intermediário & subjetiva \\
\hline 03 & subjetiva & \\
\hline
\end{tabular}


2a parte (letra $\mathrm{H}$ do protocolo)

\begin{tabular}{|l|l|}
\hline 01 & Mais errada a do desenho ou a da queimada porque faltou com a verdade (redundância). \\
\hline 02 & Mais errada a do desenho por acarretar consequências, causar danos maiores ou ser mais "permanente". \\
\hline 03 & Mais errada a do desenho ou a da queimada por conta da intenção ou ganho decorrente. \\
\hline 04 & Igualmente erradas \\
\hline
\end{tabular}

OBS: Mais avançado quanto mais considerar a intenção de enganar.

\title{
ESCORE
}

\author{
NIVEL I = de 06 a 13 pontos \\ NIVEL II = de 13,5 a 20,5 pontos \\ NIVEL III = de 21 a 28 pontos
}

OBS: As tabelas que compõem a segunda parte em cada tópico, admitem gradações na pontuação para classificação de casos intermediários, conforme análise das tendências, contradições ou hesitações da criança na entrevista como todo.

Quadro 02 - Descrição dos indicadores das entrevistas por níveis.

Como exposto no quadro as respostas das crianças foram pontuadas segundo expressassem conceitos mais avançados ou menos avançados de acordo com a teoria piagetiana do desenvolvimento moral (conforme exposto no capítulo 03, p. 38) e com nossas hipóteses. Assim, as respostas de uma criança de nível três correspondem a noções mais ligadas a autonomia, apresentadas em ambos os contextos enunciados na estória. Foi avaliada primeiramente a resposta da criança à situação de jogo em conjunto com sua resposta à situação cotidiana, em seguida pontuaram-se as respostas dadas às questões do roteiro que comparavam ambas as situações. $\mathrm{O}$ escore final foi estabelecido dividindo-se o intervalo entre a pontuação mínima (1,5 ponto por estória, sendo 01 da primeira parte e 0,5 da segunda) e a pontuação máxima (07 pontos por estória) em três níveis. 


\section{7- RESULTADOS E DISCUSSÃO}

Para a apresentação dos resultados, serão focalizados três eixos de análise: 1) Análise de cada contexto, quanto à ocorrência de indicadores e segundo os diferentes critérios estabelecidos para classificação da amostra em níveis; 2) Análises individuais, que foram organizadas quanto às categorias, quanto às situações de jogo e quanto à comparação destas com a situação hipotética; 3) Análise da regra associada a conteúdos morais. Busca-se, com isso, diferentes intersecções entre os dados que sejam demonstrativas dos fenômenos alvo de nosso estudo, isto é, as nuances contextuais e a interação da criança com a regra concreta e hipoteticamente.

\section{1- Análise dos contextos}

Este tópico destina-se a discussão das particularidades apresentadas por cada contexto aplicado, no sentido mesmo de apreender as potencialidades e adversidades desencadeadas por cada um no que diz respeito à interação com a regra. Daremos início com a comparação entre eles segundo o conjunto de indicadores prevalentes em cada um, para em seguida, apresentarmos como ficou classificada a amostra a partir dos diferentes critérios adotados.

\subsection{1 - Quanto à ocorrência dos indicadores}

Propõe-se neste ponto uma sucinta discussão das situações de jogo propostas, caracterizando-as quanto aos tipos e frequência de indicadores que apresentaram. São identificadas vias de interferências ou influências de um indicador sobre outro, acompanhando possíveis ocorrências casadas ou excludentes, além de se estabelecer possíveis comparações entre os contextos. De uma maneira geral, embora se perceba 
certa equivalência na ocorrência de alguns indicadores em todas as situações, algumas especificidades podem ser destacadas a partir da análise da Tabela 01 abaixo:

Tabela 01 - Distribuição da frequência dos indicadores por contexto

\begin{tabular}{|c|c|c|c|c|c|c|}
\hline \multicolumn{3}{|c|}{ INDICADORES } & $\begin{array}{c}\text { FECH. } \\
\text { (LUDO) }\end{array}$ & $\begin{array}{c}\text { INTERM. } \\
\text { (UNO) }\end{array}$ & $\begin{array}{c}\text { ABERTO } \\
\text { (PROTOC.) }\end{array}$ & $\mathbf{T}$ \\
\hline \multirow{8}{*}{$\begin{array}{l}\text { RELAÇÕES } \\
\text { COM A } \\
\text { REGRA }\end{array}$} & \multicolumn{2}{|c|}{ 1. Não compreende / Distorce a regra } & 104 & 52 & 21 & 177 \\
\hline & \multicolumn{2}{|c|}{ 2. Não segue a regra / Tenta burlar } & 55 & 29 & 69 & 153 \\
\hline & \multicolumn{2}{|c|}{ 3. Interpreta / Questiona a regra } & 133 & 70 & 61 & 264 \\
\hline & \multicolumn{2}{|c|}{ 4. Esquece a regra } & 110 & 58 & 17 & 185 \\
\hline & \multirow{3}{*}{$\begin{array}{l}\text { Recorre à } \\
\text { regra }\end{array}$} & 5. Acusação & 43 & 42 & 59 & 144 \\
\hline & & 6. Defesa própria & 35 & 15 & 30 & 80 \\
\hline & & 7. Defesa outro & 60 & 29 & 44 & 133 \\
\hline & \multicolumn{2}{|c|}{ 8. Faz valer a regra } & 14 & 10 & 13 & 37 \\
\hline \multirow{3}{*}{$\begin{array}{l}\text { AÇÕES NO } \\
\text { JOGAR }\end{array}$} & \multirow{3}{*}{$\begin{array}{l}\text { Interfere } \\
\text { jogada } \\
\text { alheia }\end{array}$} & 9. Benefício próprio & 06 & 13 & 03 & 22 \\
\hline & & 10. Benefício outro & 125 & 35 & 71 & 231 \\
\hline & & 11. Prejudicar & 53 & 13 & 38 & 104 \\
\hline \multirow{11}{*}{$\begin{array}{l}\text { RELAÇÕES } \\
\text { ENTRE } \\
\text { PESSOAS }\end{array}$} & \multicolumn{2}{|c|}{ 12. Efetua acordos / Busca consenso } & 06 & 35 & 146 & 187 \\
\hline & \multicolumn{2}{|c|}{ 13. Comemora azar alheio / Provoca } & 88 & 69 & 27 & 184 \\
\hline & \multicolumn{2}{|c|}{ 14. Comemora sorte alheia / Torce } & 33 & 04 & 03 & 40 \\
\hline & \multirow{3}{*}{$\begin{array}{l}\text { Recorre ao } \\
\text { adulto para }\end{array}$} & \begin{tabular}{l|l}
15. Se certificar \\
\cline { 2 - 2 }
\end{tabular} & 58 & 31 & 09 & 98 \\
\hline & & 16. Se defender & 07 & 03 & 15 & 25 \\
\hline & & 17. Acusar & 20 & 15 & 21 & 56 \\
\hline & \multirow{3}{*}{$\begin{array}{l}\text { Recorre a um } \\
\text { colega para }\end{array}$} & 18.Se certificar & 17 & 08 & 05 & 30 \\
\hline & & 19. Se defender & 04 & 02 & 07 & 13 \\
\hline & & 20. Acusar um $3^{\circ}$ & 06 & 01 & 04 & 11 \\
\hline & \multirow{2}{*}{$\begin{array}{l}\text { Questiona o } \\
\text { adulto }\end{array}$} & 21. Benefício próprio & 24 & 29 & 28 & 81 \\
\hline & & 22. Benefício outro & 24 & 34 & 26 & 84 \\
\hline
\end{tabular}

Em primeiro lugar vale observarmos os pontos de destaque de cada contexto, como forma de apreender o que cada um teve de mais característico. Como esperado, na situação aberta foram preponderantes os acordos coletivos (indicador 12), provavelmente por conta mesmo da natureza da atividade proposta que exigia que as crianças propusessem sugestões ao grupo. A natureza desta situação pode também ter sido responsável pela maior incidência do indicador 02 ("não segue a regra") neste contexto do que nos demais, pois muitas vezes a possibilidade de criar novas regras incorria na tentativa de manipula-las em favor próprio. Um fator de semelhança entre esta situação e a situação fechada foi a ocorrência do indicador 10 ("interfere na jogada alheia em benefício do outro"), que obteve a segunda maior frequência em ambas. 
Conclui-se a partir disso que a possibilidade de corrigir o adversário, ajudando-o, pode ser considerada fator independente das condições de flexibilidade da regra em si, estando talvez mais ligada a aspectos sociais do próprio ato de jogar.

Observa-se ainda que, embora o número de acusações via adulto tenha ficado bem próximo nas duas situações consideradas, a acusação via regra (indicador 05) foi mais recorrente na situação aberta, denotando maior segurança da criança com relação a regras livremente consentidas do que a regras impostas. Tomando o caminho inverso para averiguação das discrepâncias entre tais contextos temos a favor da situação aberta uma menor incidência de esquecimentos e distorções (indicadores 01 e 04), enquanto que a situação fechada teve a vantagem de proporcionar maior número de interpretações, o que inclusive se caracteriza como indicador prevalente nesta situação, que foi igualmente propicia ao recurso a regra como defesa alheia (indicador 07), ao contrário das demais, onde a regra aparece mais como base para acusações. Sobre isto cabe ainda apontar o menor uso da regra como garantia de direitos próprios (indicador 06) nos três contextos. Mesmo assim seu uso foi mais proeminente no contexto fechado, o que talvez se explique pela presença de outras vias de autoafirmação nas demais situações. Ademais, temos que a regra no contexto fechado ficava mais precisa e marcadamente explicitada, o que talvez possa também ter facilitado sua interpretação e contribuído com seu uso mais legislatório.

A situação intermediária se configurou de forma híbrida sem grandes peculiaridades e prevalências. Embora tenha se aproximado mais à situação fechada na maior parte dos critérios considerados, é possível identificar certa equivalência com a situação aberta no que diz respeito ao recurso a colegas e ao adulto (indicadores 15 a 20), sendo este último inclusive alvo de questionamentos de forma mais evidente neste contexto do que nos demais (indicadores 21 e 22). Igualmente evidentes neste contexto, 
foram as interferências na jogada alheia em beneficio próprio (indicador 09), embora tenha sido também nele em que menos se tentou burlar a regra ou prejudicar o outro (indicadores 02 e 11 respectivamente).

No que diz respeito à análise de possíveis correspondências ou relações entre os indicadores outras interessantes considerações podem ser colocadas. A primeira delas se refere a certo paralelismo ou concomitância percebida na ocorrência de alguns deles, como é o caso das ações de corrigir o erro do adversário ou interferir em sua jogada que geralmente vinham acompanhadas do recurso ao adulto como meio de certificação. Porém, em se tratando da ação de questionar uma jogada houve maior preferência por fazê-lo diretamente e com referência a regra (indicador 05). Tal paralelismo pode ser observado também entre os esquecimentos da regra e sua distorção, contudo em menor grau. Um segundo aspecto a ser destacado refere-se a ocorrências de provocações (indicador 13), que foram mais desencadeadas pelo contexto fechado, o qual foi ao mesmo tempo o espaço onde mais frequentemente se demonstrou apoio ou torcida pelo adversário (indicador 14), ambos proporcionados talvez pelo próprio caráter competitivo da atividade.

Com relação às categorias, observa-se, que no quesito relações com a regra o contexto fechado obteve maior incidência de indicadores, enquanto que na categoria relações entre pessoas prevalece o contexto aberto. Uma possível explicação seria o fato, já apontado, de no primeiro deles a regra ser colocada mais precisa e objetivamente, e no segundo ela ser propriamente fruto de discussões. Tal constatação corrobora nossa premissa inicial de que a relação entre pessoas é fundamental ao bom uso e entendimento da regra enquanto mecanismo de regulação social.

Como discutido inicialmente, houve de maneira geral uma distribuição equilibrada de indicadores em todos os contextos, ficando as peculiaridades de cada um 
a cargo da própria condição em que as regras foram estabelecidas, ou seja, pode se verificar influências positivas e negativas da proposição da regra enquanto código préestabelecido ou acordo momentâneo, pois o que se ganhou em flexibilidade, pelo menos em nossa amostra, perdeu-se em comprometimento, dada, como vimos, a grande incidência na situação aberta de alterações individuais na regra sem a devida consideração de seu caráter coletivo, o que talvez se explique pela própria idade das crianças. Tal fato, inclusive, pode ser bem ilustrativo de como as alterações no meio não bastam por si só ao desenvolvimento, é necessário que elas sejam fonte de regulações e compensações para o próprio sujeito.

Como meio de complementar as informações prestadas até então vejamos como ficou classificada nossa amostra em cada um destes contextos de jogo.

\subsection{2 - Quanto aos critérios estabelecidos para classificação da amostra em níveis}

Veremos neste ponto, rapidamente, como ficou distribuída nossa amostra de acordo com a atribuição de importâncias diferenciadas às três categorias de indicadores estabelecidas para a análise, a saber: relações com a regra, relações entre ações no jogar e relações entre pessoas. Para tanto, tomaremos como base os dados reunidos na Tabela 02.

Tabela 02 - Distribuição da amostra segundo os três critérios de classificação

\begin{tabular}{|c|c|c|c|c|c|c|c|c|c|c|c|c|}
\hline $\mathbf{N}$ & $\mathbf{C}$ & $\mathbf{L 1}$ & $\mathbf{L 2}$ & $\mathbf{L 3}$ & $\mathbf{U}$ & $\mathbf{U 1}$ & $\mathbf{U 2}$ & $\mathbf{U 3}$ & $\mathbf{S}$ & $\mathbf{S 1}$ & $\mathbf{S 2}$ & $\mathbf{S 3}$ \\
\hline $\mathbf{I}$ & 32 & 28 & 32 & 33 & 23 & 25 & 25 & 26 & 04 & 05 & 06 & 03 \\
$(58,2)$ & $(51,9)$ & $(58,2)$ & $(60)$ & $(45,1)$ & $(43,9)$ & $(45,5)$ & $(46,4)$ & $(8,3)$ & $(10)$ & $(11,8)$ & $(6,1)$ \\
\hline & 02 & 03 & 02 & 02 & 05 & 08 & 05 & 06 & 05 & 15 & 08 & 15 \\
II & $(3,6)$ & $(5,5)$ & $(3,6)$ & $(3,6)$ & $(9,8)$ & $(14)$ & $(09)$ & $(10,7)$ & $(10,4)$ & $(30)$ & $(15,7)$ & $(30,6)$ \\
\hline & 21 & 23 & 21 & 20 & 23 & 24 & 25 & 24 & 39 & 30 & 37 & 31 \\
III & $(38,2)$ & $(42,6)$ & $(38,2)$ & $(36,4)$ & $(45,1)$ & $(42,1)$ & $(45,5)$ & $(42,9)$ & $(81,3)$ & $(60)$ & $(72,5)$ & $(63,3)$ \\
\hline Total & 55 & 54 & 55 & 55 & 51 & 57 & 55 & 56 & 49 & 50 & 51 & 49 \\
\hline
\end{tabular}




\section{Legenda:}

$\mathrm{L}=$ Classificação obtida pelo sujeito na situação fechada (Ludo) pelo critério de soma absoluta.

$\mathrm{L} 1$ = Classificação obtida pelo sujeito na situação fechada (Ludo) pelo critério $01-(5 \times \mathrm{R})+(3 \times \mathrm{A})+(2 \times \mathrm{P})$.

L2 = Classificação obtida pelo sujeito na situação fechada (Ludo) pelo critério $02-(4 \times R)+(3 \times A)+(3 \times P)$.

L3 = Classificação obtida pelo sujeito na situação fechada (Ludo) pelo critério $03-(5 \times R)+(2 \times A)+(3 \times P)$.

$\mathrm{U}=$ Classificação obtida pelo sujeito na situação intermediária (Uno) pelo critério de soma absoluta.

$\mathrm{U} 1=$ Classificação obtida pelo sujeito na situação intermediária (Uno) pelo critério $01-(5 \times \mathrm{R})+(3 \times \mathrm{A})+(2 \times \mathrm{P})$.

$\mathrm{U} 2$ = Classificação obtida pelo sujeito na situação intermediária (Uno) pelo critério $02-(4 \times \mathrm{R})+(3 \times \mathrm{A})+(3 \times \mathrm{P})$.

U3 = Classificação obtida pelo sujeito na situação intermediária (Uno) pelo critério $03-(5 \times R)+(2 \times \mathrm{A})+(3 \times \mathrm{P})$.

$\mathrm{S}=$ Classificação obtida pelo sujeito na situação aberta (protocolo) pelo critério de soma absoluta.

$\mathrm{S} 1$ = Classificação obtida pelo sujeito na situação aberta (protocolo) pelo critério $01-(5 \times \mathrm{R})+(3 \times \mathrm{A})+(2 \times \mathrm{P})$.

$\mathrm{S} 2=$ Classificação obtida pelo sujeito na situação aberta (protocolo) pelo critério $02-(4 \times \mathrm{R})+(3 \times \mathrm{A})+(3 \times \mathrm{P})$.

S3 = Classificação obtida pelo sujeito na situação aberta (protocolo) pelo critério $03-(5 \times R)+(2 \times A)+(3 \times P)$.

Obs: Os valores entre parênteses expressam a porcentagem.

No que diz respeito à situação fechada, na qual as crianças jogaram o jogo Ludo conforme regras pré-estabelecidas pelas experimentadoras, nota-se que grande parte da amostra se estabeleceu no nível I, ficando em destaque os indicadores referentes a relações com a regra e relações entre pessoas (L2 e L3 respectivamente), o que, aliás, nos fornece indícios de que as crianças do nível III foram assim classificadas por conta da categoria ações no jogar, fato este confirmado pela prevalência do índice L1 neste nível.

Para a situação intermediária observamos que, interessantemente, a amostra se dividiu entre os níveis I e III, sendo que no NI destacam-se, timidamente, as relações entre pessoas e o NIII as relações com a regra. O que se explica talvez, pelo próprio formato da tarefa associado ao instrumento utilizado. Geralmente, os grupos se dividiam entre crianças que conheciam o UNO e o jogavam frequentemente e crianças que o desconheciam completamente. Com isto, a possibilidade de mudar o regulamento ficava em grande parte restrita aos primeiros, que o faziam muitas vezes prescindindo da aprovação coletiva, com base em acordos já estabelecidos de antemão em experiências anteriores com o jogo. Restava assim aos segundos, recorrer aos colegas ou ao adulto para melhor entendimento do jogo, mesmo quando da realização de partidas consecutivas. 
Considerando agora a situação aberta, é notória a prevalência de crianças no nível III, denotando que uma maior abertura a trocas e discussões poderia ser contributiva ao uso mais avançado da regra, pelo menos enquanto código a ser compartilhado coletivamente. Algo inclusive já sugerido anteriormente pela análise isolada da ocorrência dos indicadores. Observamos, além disso, que não há predominâncias significativas entre os índices, revelando a existência de um maior equilíbrio entre as três categorias de análise e fortalecendo nossa colocação anterior, a respeito de um uso, senão mais consciente, pelo menos mais coerente da regra neste contexto.

Diante do exposto até aqui, vemos que, na verdade, cada contexto mobilizou um tipo de interação com a regra condizente com suas configurações e exigências. Enquanto que na situação fechada jogar bem significava entender e cumprir a regra colocada de forma a elaborar estratégias para ganhar jogo honestamente, na situação aberta jogar bem demandava para além do simples entendimento e elaborada interpretação da regra, era preciso se posicionar também frente ao outro. Foi exatamente o meio termo entre estes dois posicionamentos (frente à regra e frente ao outro) que se manifestou na situação intermediária, onde a possibilidade de modificar a regra ou simplesmente adicionar outras, exigia ora a atenção ao regulamento ora a capacidade de se fazer aceito. Donde se conclui que a boa interação com a regra se traduz, em nossos dados, tanto pela capacidade de entendê-la e cumpri-la adequadamente como pelo ato de modificá-la (ou criá-la) em prol de um bem maior a todos os envolvidos, resguardando o princípio de reciprocidade nas relações.

Como sabemos a interpretação dos dados com base apenas na classificação geral da amostra, incorre no risco de deixar escapar peculiaridades importantíssimas e 
fundamentais à devida compreensão de nosso objeto de estudo. Por conta disto apresentaremos no tópico seguinte um pequeno apanhado de casos individuais.

\section{2 - Análises Individuais}

Necessário se faz neste momento de nossa análise tecer algumas considerações a respeito dos diferentes cruzamentos realizados entre os dados. Como exposto dentre os procedimentos de análise, após a obtenção da frequência de emissão de indicadores por cada um dos sujeitos procedeu-se à sua classificação em níveis, segundo as categorias e segundo as situações propostas, conforme diferentes critérios de distribuição de importância entre os itens avaliados, os quais foram definidos a partir do que seria o mais desejável do ponto de vista da fundamentação teórica. Pois bem, para a apresentação desta parte dos resultados foram elaboradas tabelas de frequência demonstrativas de como nossa amostra se comportou de acordo com cada cruzamento proposto. Como complemento a tais tabelas apresentaremos a discussão de alguns casos individuais.

\subsection{1- Por categorias:}

São efetuados neste item os cruzamentos da categoria relações com a regra com a categoria relações entre pessoas e da mesma com a categoria ações no jogar. $\mathrm{O}$ primeiro deles busca verificar o quanto o fator de interação social se mostra ou não evidente em nosso fenômeno, já o segundo se destina a correlacionar a prática e a consciência da regra. Comecemos pelo primeiro deles. 
Tabela 03 - Distribuição das crianças em níveis quanto à relação com a regra e relação entre pessoas.

\begin{tabular}{|c|c|c|c|c|}
\hline $\mathbf{P}$ & $\mathbf{N I}$ & NII & NIII & Total \\
\hline NI & $\begin{array}{c}10 \\
(17,85)\end{array}$ & $\begin{array}{c}09 \\
(16,07)\end{array}$ & $\begin{array}{c}07 \\
(12,5)\end{array}$ & 26 \\
\hline NII & $\begin{array}{c}00 \\
(00)\end{array}$ & $\begin{array}{c}01 \\
(1,78)\end{array}$ & $\begin{array}{c}01 \\
(1,78)\end{array}$ & 02 \\
\hline NIII & $\begin{array}{c}09 \\
(16,07)\end{array}$ & $\begin{array}{c}04 \\
(7,14)\end{array}$ & $\begin{array}{c}15 \\
(26,8)\end{array}$ & 27 \\
\hline Total & 19 & 14 & 23 & 56 \\
\hline
\end{tabular}

$\mathrm{R}=$ Categoria relações com a regra.

$\mathrm{P}=$ Categoria relações com as pessoas.

$\mathrm{NI}=$ soma das frequências dos indicadores 01 e 04 para $\mathrm{R}$ e dos indicadores $13,15,16$ e 17 para $\mathrm{P}$ em cada situação proposta.

$\mathrm{NII}=$ soma das frequências dos indicadores 02,06 e 05 para $\mathrm{R}$ e dos indicadores 18,19 e 20 para $\mathrm{P}$ em cada situação proposta.

$\mathrm{NIII}=$ soma das frequências dos indicadores 03,07 e 08 para $\mathrm{R}$ e dos indicadores 12, 14, 21 e 22 para $\mathrm{P}$ em cada situação proposta.

Obs: Foi utilizada a soma absoluta, sem utilizar critérios de distribuição de importância entre os fatores avaliados. Os valores entre parênteses expressam a porcentagem.

Como pode ser verificado na Tabela 03, 26 das 56 crianças analisadas $(46,4 \%)$ obtiveram o mesmo nível para ambos os fatores avaliados, indicando, portanto, uma correspondência entre eles, ou seja, lidar de modo avançado com as regras significa se relacionar também de modo avançado com as pessoas, o mesmo valendo para as atuações medianas e inferiores. Refletindo sobre este cruzamento de dados, poderíamos dizer que a relação entre as regras e as pessoas precisa ser melhor investigada, pois só obtivemos informações claras para cerca de $50 \%$ de nossa amostra, sendo que o restante apresentou combinações não harmônicas entre as relações com as regras e com as pessoas, o que não permitiu fortalecer a relação apontada teoricamente entre estes aspectos e a correspondência entre eles.

Podemos verificar ainda que, dentre as combinações desarmônicas, o nível de relação com a regra superou o de relações com as pessoas em 30,35\% dos casos (17 sujeitos em 56), enquanto que o inverso ocorreu em 23,21\% (13 em 56). Embora muito próximos numericamente, tais índices podem ser demonstrativos de que, em um 
momento de transição (vide idade dos sujeitos) a relação com a regra se sobressai até que as relações interpessoais sejam melhor consolidadas pela via da reciprocidade.

Passemos, então, a análise de alguns casos, no intuito de avaliarmos alguns sujeitos de mesmo nível, porém com percursos diferenciados em termos de atuações nas diferentes situações propostas (para a leitura de todos os gráficos individuais solicita-se a consideração da legenda abaixo).

\begin{tabular}{|c|}
\hline Legenda: \\
\hline $\begin{array}{l}\text { L = Classificação obtida pelo sujeito na situação fechada (Ludo) pelo critério de soma absoluta. } \\
\text { L1 = Classificação obtida pelo sujeito na situação fechada (Ludo) pelo critério } 01-(5 \times \mathrm{R})+(3 \times \mathrm{A})+(2 \times \mathrm{P}) \text {. } \\
\mathrm{L} 2 \text { = Classificação obtida pelo sujeito na situação fechada (Ludo) pelo critério } 02-(4 \times \mathrm{R})+(3 \times \mathrm{A})+(3 \times \mathrm{P}) . \\
\mathrm{L} 3 \text { = Classificação obtida pelo sujeito na situação fechada (Ludo) pelo critério } 03-(5 \times \mathrm{R})+(2 \times \mathrm{A})+(3 \times \mathrm{P}) .\end{array}$ \\
\hline $\begin{array}{l}\text { U = Classificação obtida pelo sujeito na situação intermediária (Uno) pelo critério de soma absoluta. } \\
\text { U1 = Classificação obtida pelo sujeito na situação intermediária (Uno) pelo critério } 01-(5 \times \mathrm{R})+(3 \times \mathrm{A})+(2 \times \mathrm{P}) \text {. } \\
\mathrm{U} 2 \text { = Classificação obtida pelo sujeito na situação intermediária (Uno) pelo critério } 02-(4 \times \mathrm{R})+(3 \times \mathrm{A})+(3 \times \mathrm{P}) . \\
\mathrm{U} 3 \text { = Classificação obtida pelo sujeito na situação intermediária (Uno) pelo critério } 03-(5 \times \mathrm{R})+(2 \times \mathrm{A})+(3 \times \mathrm{P}) .\end{array}$ \\
\hline $\begin{array}{l}\mathrm{S}=\text { Classificação obtida pelo sujeito na situação aberta (protocolo) pelo critério de soma absoluta. } \\
\text { S1 = Classificação obtida pelo sujeito na situação aberta (protocolo) pelo critério } 01-(5 \times \mathrm{R})+(3 \times \mathrm{A})+(2 \times \mathrm{P}) \\
\text { S2 = Classificação obtida pelo sujeito na situação aberta (protocolo) pelo critério } 02-(4 \times \mathrm{R})+(3 \times \mathrm{A})+(3 \times \mathrm{P}) \\
\mathrm{S} 3 \text { = Classificação obtida pelo sujeito na situação aberta (protocolo) pelo critério } 03-(5 \times \mathrm{R})+(2 \times \mathrm{A})+(3 \times \mathrm{P})\end{array}$ \\
\hline $\begin{array}{l}\mathrm{R} \text { = Classificação obtida pelo sujeito na categoria relações com a regra pelo critério de soma absoluta. } \\
\mathrm{R} 1 \text { = Classificação obtida pelo sujeito na categoria relações com a regra pelo critério } 01-(5 \times \mathrm{L})+(2,5 \times \mathrm{U})+(2,5 \times \mathrm{S}) \\
\mathrm{R} 2 \text { = Classificação obtida pelo sujeito na categoria relações com a regra pelo critério } 02-(2,5 \times \mathrm{L})+(2,5 \times \mathrm{U})+(5 \times \mathrm{S})\end{array}$ \\
\hline $\begin{array}{l}\text { A = Classificação obtida pelo sujeito na categoria ações no jogar pelo critério de soma absoluta. } \\
\text { A1 = Classificação obtida pelo sujeito na categoria ações no jogar pelo critério } 01-(5 \times \mathrm{L})+(2,5 \times \mathrm{U})+(2,5 \times \mathrm{S}) \\
\text { A2 = Classificação obtida pelo sujeito na categoria ações no jogar pelo critério } 02-(2,5 \times \mathrm{L})+(2,5 \times \mathrm{U})+(5 \times \mathrm{S})\end{array}$ \\
\hline $\begin{array}{l}\mathrm{P}=\text { Classificação obtida pelo sujeito na categoria relações com as pessoas pelo critério de soma absoluta. } \\
\mathrm{P} 1 \text { = Classificação obtida pelo sujeito na categoria relações com as pessoas pelo critério } 01-(5 \times \mathrm{L})+(2,5 \times \mathrm{U})+(2,5 \times \mathrm{S}) \\
\mathrm{P} 2 \text { = Classificação obtida pelo sujeito na categoria relações com as pessoas pelo critério } 02-(2,5 \times \mathrm{L})+(2,5 \times \mathrm{U})+(5 \times \mathrm{S}) \text {. }\end{array}$ \\
\hline
\end{tabular}

\section{Nivel III em ambos (3RX3P)}

Figura 01 - Gráfico de acompanhamento individual do sujeito 08 (KAT).

\begin{tabular}{|c|c|c|c|c|c|c|c|c|c|c|c|c|c|c|c|c|c|c|c|c|c|c|c|}
\hline $\mathbf{S}$ & $\mathbf{N}$ & $\mathbf{L}$ & L1 & L2 & L3 & $\mathbf{U}$ & U1 & U2 & U3 & $\mathbf{S}$ & S1 & $\mathbf{S 2}$ & S3 & $\mathbf{R}$ & R1 & $\mathbf{R 2}$ & $\mathbf{A}$ & A1 & A2 & $\mathbf{P}$ & P1 & P2 & $\mathbf{E}$ \\
\hline \multirow{3}{*}{$\begin{array}{c}8 . \\
\text { KAT }\end{array}$} & I & & & & & & • & $\bullet$ & • & & & & & & & & $\bullet$ & - & - & & & & \\
\hline & II & & & & & & & & & & & & & & & & & & & & & & \\
\hline & III & • & • & • & • & - & & $\bullet$ & & - & • & • & • & - & • & • & & & & - & • & - & - \\
\hline
\end{tabular}

Figura 02 - Gráfico de acompanhamento individual do sujeito 11 (JOA).

\begin{tabular}{|c|c|c|c|c|c|c|c|c|c|c|c|c|c|c|c|c|c|c|c|c|c|c|c|}
\hline $\mathbf{S}$ & $\mathbf{N}$ & $\mathbf{L}$ & L1 & L2 & $\mathbf{L 3}$ & $\mathbf{U}$ & U1 & $\mathbf{U 2}$ & U3 & $\mathbf{S}$ & S1 & $\mathbf{S 2}$ & S3 & $\mathbf{R}$ & R1 & $\mathbf{R 2}$ & $\mathbf{A}$ & A1 & A2 & $\mathbf{P}$ & P1 & $\mathbf{P 2}$ & $\mathbf{E}$ \\
\hline \multirow{3}{*}{$\begin{array}{c}11 . \\
\text { JOA }\end{array}$} & I & & & & & & & & & & & & & & & & • & • & • & & & & \\
\hline & II & & & & & & & & & - & - & • & • & & $\bullet$ & & & & & & & & - \\
\hline & III & - & - & • & - & - & • & • & - & & & & & - & - & • & & & & • & $\bullet$ & • & \\
\hline
\end{tabular}


Figura 03 - Gráfico de acompanhamento individual do sujeito 24 (JOA).

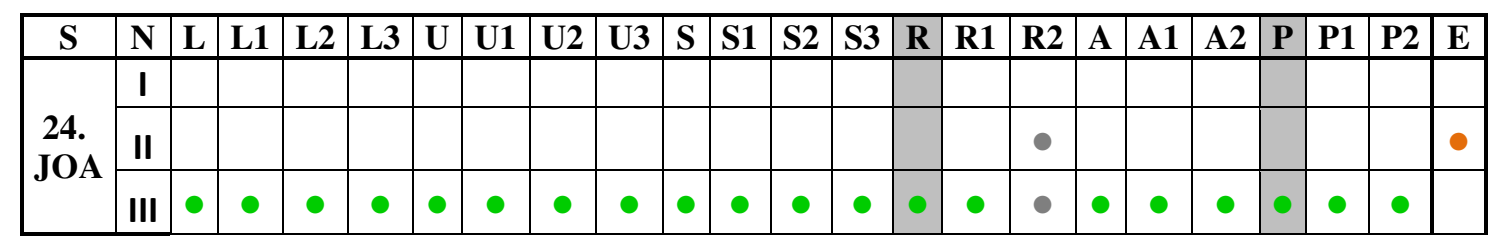

Pelo exame comparativo dos gráficos acima, notam-se diferentes manifestações para os integrantes do NIII. Os avanços de KAT, por exemplo, decorrem duplamente da situação fechada e da situação aberta, enquanto que para JOA(11) parece ser a situação intermediária a prevalente, pois além de ter ficado no nível II para a situação aberta, seus índices em R1(critério que estabelece maior peso ao contexto fechado) mostram um empate entre os níveis II e III. Por fim em JOA(24), vemos maior estabilidade embora a situação aberta tenha sido também menos favorável, como pode ser visto em seu R2. Conclui-se então que dentre os três sujeitos de NIII considerados JOA(24) é o mais avançado, não só por ter se mantido estável, mas por ter tido melhor desempenho nos quesitos avaliados nas situações em que eles eram menos esperados. Prossigamos com exemplos do NI.

Nível I em ambos (1RXIP)

Figura 04 - Gráfico de acompanhamento individual do sujeito 33 (IZA).

\begin{tabular}{|c|c|c|c|c|c|c|c|c|c|c|c|c|c|c|c|c|c|c|c|c|c|c|c|}
\hline $\mathbf{S}$ & $\mathbf{N}$ & $\mathbf{L}$ & L1 & $\mathbf{L 2}$ & L3 & $\mathbf{U}$ & U1 & $\mathbf{U 2}$ & $\mathbf{U 3}$ & $\mathbf{S}$ & S1 & S2 & \begin{tabular}{|l|}
$\mathbf{S 3}$ \\
\end{tabular} & $\mathbf{R}$ & R1 & $\mathrm{R} 2$ & $\mathbf{A}$ & A1 & A2 & $\mathbf{P}$ & P1 & P2 & $\mathbf{E}$ \\
\hline \multirow{3}{*}{$\begin{array}{r}33 . \\
\text { IZA }\end{array}$} & I & - & - & - & • & - & - & • & • & - & • & • & - & - & - & - & & & & - & • & • & \\
\hline & II & & & & & & & & & & & & & & & & & & & & & & \\
\hline & III & & & & & & & & • & & & & & & & & • & • & • & & & & • \\
\hline
\end{tabular}

Figura 05 - Gráfico de acompanhamento individual do sujeito 49 (PED).

\begin{tabular}{|c|c|c|c|c|c|c|c|c|c|c|c|c|c|c|c|c|c|c|c|c|c|c|c|}
\hline $\mathbf{S}$ & $\mathbf{N}$ & $\mathbf{L}$ & L1 & L2 & L3 & $\mathbf{U}$ & U1 & $\mathrm{U} 2$ & U3 & $S$ & S1 & S2 & S3 & $\mathbf{R}$ & R1 & $\mathrm{R} 2$ & $\mathbf{A}$ & A1 & A2 & $\mathbf{P}$ & P1 & P2 & $\mathbf{E}$ \\
\hline \multirow{3}{*}{$\begin{array}{l}49 . \\
\text { PED }\end{array}$} & I & - & $\bullet$ & • & - & • & • & • & - & & & & & • & • & - & & & & • & $\bullet$ & - & \\
\hline & II & & & & & & & & & & & & & & & & & & & & & & • \\
\hline & III & & & & & & & & & • & • & • & • & & & & - & • & • & & & • & \\
\hline
\end{tabular}


Aqui vemos novamente diferentes fatos explicativos para sujeitos de mesmo nível. O primeiro gráfico (IZA) demonstra uma trajetória sem muitas nuances, tendo sido, portanto, as três situações igualitárias em suas influências sobre os quesitos por ora considerados. Demonstrando-se, ademais, mais relevante para este sujeito as ações no jogar. PED (49), por sua vez, obteve avanços na situação aberta, mas que não repercutiram nos itens em questão, ficando também mais atrelados às ações no jogar. Daremos seguimento agora, com uma breve comparação entre sujeitos que se destacaram nas relações com a regra e sujeitos que se destacaram nas relações entre pessoas.

Niveis diferentes para cada categoria (3RX1P e 3PX1R)

Figura 06 - Gráfico de acompanhamento individual do sujeito 51 (ART).

\begin{tabular}{|c|c|c|c|c|c|c|c|c|c|c|c|c|c|c|c|c|c|c|c|c|c|c|c|}
\hline $\mathbf{S}$ & $\mathbf{N}$ & $\mathbf{L}$ & L1 & $\mathbf{L 2}$ & L3 & $\mathbf{U}$ & U1 & U2 & $\mathbf{U 3}$ & $\mathbf{S}$ & S1 & S2 & S3 & $\mathbf{R}$ & R1 & $\mathbf{R 2}$ & $\mathbf{A}$ & A1 & A2 & $\mathbf{P}$ & P1 & $\mathbf{P 2}$ & $\mathbf{E}$ \\
\hline \multirow{3}{*}{$\begin{array}{r}51 . \\
\text { ART }\end{array}$} & I & & & & & • & • & • & • & & & & & & & & & & & - & - & $\bullet$ & \\
\hline & II & & & & & & & & & & & & & & & & & & & & & & - \\
\hline & III & - & - & - & • & & & & & - & - & - & - & - & - & - & - & - & - & & & - & \\
\hline
\end{tabular}

Figura 07 - Gráfico de acompanhamento individual do sujeito 27 (ART).

\begin{tabular}{|c|c|c|c|c|c|c|c|c|c|c|c|c|c|c|c|c|c|c|c|c|c|c|c|}
\hline S & N & L & L1 & L2 & L3 & U & U1 & U2 & U3 & S & S1 & S2 & S3 & R & R1 & R2 & A & A1 & A2 & P & P1 & P2 & E \\
\hline \multirow{3}{*}{$\begin{array}{c}\text { 27. } \\
\text { ART }\end{array}$} & I & $\bullet$ & $\bullet$ & $\bullet$ & $\bullet$ & $\bullet$ & $\bullet$ & $\bullet$ & $\bullet$ & & & & & & $\bullet$ & & & & & & & & \\
\cline { 2 - 14 } & II & & & & & & & & & & & & & & & & & & & & & & $\bullet$ \\
\cline { 2 - 16 } & III & & & & & & & & & $\bullet$ & $\bullet$ & $\bullet$ & $\bullet$ & & & $\bullet$ & $\bullet$ & $\bullet$ & $\bullet$ & & $\bullet$ & $\bullet$ & \\
\hline
\end{tabular}

Começando pela análise da Figura 06, vemos que o pouco avanço de ART (51) na categoria relações com as pessoas se deu, principalmente na situação intermediária, além disso, seu bom desempenho na situação aberta ocorreu mais por conta da categoria ações no jogar do que por suas habilidades interpessoais, tanto que mesmo com ênfase nos indicadores desta situação (P2) ele ainda empata. Conclui-se, portanto, que situações regradas com maior apelo à reciprocidade ainda se constituem difíceis para 
este sujeito, ficando seu avanço com relação às regras dependente de uma maior estruturação contextual. O oposto ocorre com ART (27), que avançou exatamente na situação aberta, porém tal avanço restringiu-se às suas trocas interindividuais, ficando pouco evidente em seu uso das regras.

Ilustrado nosso primeiro cruzamento entre os dados, voltemo-nos neste ponto para a segunda intersecção proposta. Como sabido, outro aspecto relevante aos nossos propósitos é a relação entre prática e consciência da regra, o qual será avaliado pelo cruzamento entre as categorias relações com a regra e ações no jogar, como demonstrado na Tabela 04.

Tabela 04 - Distribuição das crianças em níveis quanto a relações com a regra e ações no jogar

\begin{tabular}{|c|c|c|c|c|}
\hline $\mathbf{R}$ & NI & NII & NIII & Total \\
\hline NI & $\begin{array}{c}05 \\
(9,61)\end{array}$ & $\begin{array}{c}04 \\
(7,69)\end{array}$ & $\begin{array}{c}03 \\
(5,76)\end{array}$ & 12 \\
\hline NII & $\begin{array}{c}02 \\
(3,84)\end{array}$ & $\begin{array}{c}00 \\
(00)\end{array}$ & $\begin{array}{c}00 \\
(00)\end{array}$ & 02 \\
\hline NIII & $\begin{array}{c}08 \\
(15,38)\end{array}$ & $\begin{array}{c}11 \\
(21,15)\end{array}$ & $\begin{array}{c}19 \\
(36,53)\end{array}$ & 38 \\
\hline Total & 15 & 15 & 22 & 52 \\
\hline
\end{tabular}

$\mathrm{R}=$ Categoria relações com a regra.

$\mathrm{A}=$ Categoria relações entre ações no jogar.

$\mathrm{NI}=$ soma das frequências dos indicadores 01 e 04 para $\mathrm{R}$ e do indicador 11 para A em cada situação proposta.

$\mathrm{NII}=$ soma das frequências dos indicadores 02,06 e 05 para R e do indicador 09 para A em cada situação proposta.

NIII = soma das frequências dos indicadores 03, 07 e 08 para R e do indicador 10 para A em cada situação proposta.

Obs: Foi utilizada a soma absoluta, sem utilizar critérios de distribuição de importância entre os fatores avaliados. Os valores entre parênteses expressam a porcentagem.

Aqui mais uma vez encontramos maior número de sujeitos no nível III para ambos os aspectos, fato este indicativo de coerência entre eles. Tal coerência se repete inclusive no intervalo do nível II para regras com nível III de ações, que obteve a segunda maior frequência, totalizando um pouco mais da metade de nossa amostra. Cabe ressaltar, entretanto, a incidência de sujeitos no nível III com relação à categoria ações no jogar, porém, com índice de nível I na categoria relações com a regra, 
significando, portanto, que embora a consciência da regra corresponda à adequada prática da mesma, o inverso não ocorre, ou seja, uma boa prática da regra nem sempre vem acompanhada com a devida consciência a respeito dela. Vejamos os casos:

\section{Nivel III em ambos (3RX3A)}

Figura 08 - Gráfico de acompanhamento individual do sujeito 48 (BRU).

\begin{tabular}{|c|c|c|c|c|c|c|c|c|c|c|c|c|c|c|c|c|c|c|c|c|c|c|c|}
\hline $\mathbf{S}$ & $\mathbf{N}$ & \begin{tabular}{|l|}
$\mathbf{L}$ \\
\end{tabular} & L1 & $\mathbf{L 2}$ & $\mathrm{L3}$ & $\overline{\mathbf{U}}$ & U1 & $\mathrm{U} 2$ & U3 & $\underline{S}$ & S1 & S2 & $\mathbf{S 3}$ & $\mathbf{R}$ & R1 & $\mathrm{R2}$ & $\mathbf{A}$ & $\mathbf{A 1}$ & $\mathrm{A2}$ & $\underline{\mathbf{P}}$ & $\mathbf{P 1}$ & $\mathbf{P 2}$ & $\mathbf{E}$ \\
\hline \multirow{3}{*}{$\begin{array}{c}48 . \\
\text { BRU }\end{array}$} & I & • & • & • & • & & & & & & & & & & - & & & & & & & & \\
\hline & II & & & & & & & & & & & & & & & & & & & & & & \\
\hline & III & & & & & • & • & • & • & • & • & • & • & • & • & • & • & • & $\bullet$ & • & • & $\bullet$ & • \\
\hline
\end{tabular}

Figura 09 - Gráfico de acompanhamento individual do sujeito 20 (GUS).

\begin{tabular}{|c|c|c|c|c|c|c|c|c|c|c|c|c|c|c|c|c|c|c|c|c|c|c|c|}
\hline S & N & L & L1 & L2 & L3 & U & U1 & U2 & U3 & S & S1 & S2 & S3 & R & R1 & R2 & A & A1 & A2 & P & P1 & P2 & E \\
\hline \multirow{2}{*}{$\begin{array}{c}\text { 20. } \\
\text { GUS }\end{array}$} & I & & & & & $\bullet$ & & & & & & & & & & & & & & $\bullet$ & $\bullet$ & & \\
& II & & & & & & & & & $\bullet$ & $\bullet$ & $\bullet$ & $\bullet$ & & & & & & & & & \\
& III & $\bullet$ & $\bullet$ & $\bullet$ & $\bullet$ & $\bullet$ & & & & $\bullet$ & & $\bullet$ & $\bullet$ & & & & & & & & & & \\
\hline
\end{tabular}

Os gráficos são bem evidentes quanto à diferença de percurso dos dois sujeitos considerados. BRU obteve melhores êxitos com a flexibilização na proposição das regras, tanto que até seu índice de relações com pessoas encontra-se elevado. Constatase, além disso, uma alteração em seu R1(critério onde a situação fechada ganha maior relevância) que acaba empatado entre os níveis I e III. Tais êxitos de BRU nas situações menos estruturadas demonstram uma prática da regra mais bem consolidada e integrada aos demais fatores em jogo, do que a de GUS que, embora esteja classificada também no nível III, parece decorrer de sua boa atuação no jogo em termos de estratégia, e não necessariamente do uso social da regra (vide comparativamente seu L e seu S). Este tipo de conduta, aliás, foi geralmente mais comum entre os sujeitos de NII para regra e NIII para ação como veremos a seguir. 
Nível II na categoria relações com a regra e nível III em ações no jogar (2RX3A)

Figura 10 - Gráfico de acompanhamento individual do sujeito 12 (ANA).

\begin{tabular}{|c|c|c|c|c|c|c|c|c|c|c|c|c|c|c|c|c|c|c|c|c|c|c|c|}
\hline $\mathbf{S}$ & $\mathbf{N}$ & $\mathbf{L}$ & L1 & L2 & L3 & $\mathbf{U}$ & U1 & U2 & U3 & S & S1 & S2 & S3 & $\mathbf{R}$ & R1 & R2 & $\mathbf{A}$ & A1 & A2 & $\mathbf{P}$ & P1 & P2 & $\mathbf{E}$ \\
\hline \multirow{3}{*}{$\begin{array}{c}12 . \\
\text { ANA }\end{array}$} & I & • & & • & • & & & & & & & & & & & & & & & • & - & - & \\
\hline & II & & & & & & & & & - & • & • & - & - & - & - & & & & & & & \\
\hline & III & $\bullet$ & - & • & & - & • & • & • & & & & & & & & - & - & - & & & & - \\
\hline
\end{tabular}

Figura 11 - Gráfico de acompanhamento individual do sujeito 17 (ISA).

\begin{tabular}{|c|c|c|c|c|c|c|c|c|c|c|c|c|c|c|c|c|c|c|c|c|c|c|c|}
\hline $\mathbf{S}$ & $\mathbf{N}$ & $\mathbf{L}$ & L1 & L2 & L3 & $\mathbf{U}$ & U1 & $\mathrm{U} 2$ & U3 & $\mathbf{S}$ & S1 & S2 & S3 & $\mathbf{R}$ & R1 & $\mathbf{R 2}$ & $\mathbf{A}$ & A1 & A2 & $\mathbf{P}$ & P1 & P2 & $\mathbf{E}$ \\
\hline \multirow{3}{*}{$\begin{array}{c}17 . \\
\text { ISA }\end{array}$} & I & $\bullet$ & $\bullet$ & - & - & • & • & - & • & & & & & & & & & & & $\bullet$ & - & - & \\
\hline & II & & & & & & & & & & $\bullet$ & & • & • & • & $\bullet$ & & & & & & & $\bullet$ \\
\hline & III & & & & & & & & & • & $\bullet$ & • & - & & - & & - & • & - & & & & \\
\hline
\end{tabular}

Ao analisarmos as figuras, observamos que a trajetória de ANA (Figura 10) é bem representativa do fenômeno que descrevemos anteriormente para GUS (Figura 09), vemos que sua relação com a regra, por se dar de forma mais efetiva nos contextos regrados de antemão, acaba por se vincular mais a uma conduta de conformidade do que necessariamente interpretativa. $\mathrm{Na}$ verdade, o que os diferencia e talvez explique suas diferentes classificações é que GUS manifestou na situação aberta mais indicadores ligados a relações com as pessoas enquanto ANA até mesmo nesta situação ficou mais restrita às ações no jogar. Fato semelhante ocorre com ISA, que embora apresente melhoras na situação aberta, se destaca mais por suas jogadas do que por seu relacionamento com a regra ou com as pessoas. Ainda que com maiores destaques para suas ações no jogar, o nível atingido na categoria relações com as regras é demonstrativo de que, para estes sujeitos, a prática e consciência da regra implicavamse mutuamente. Uma maior distorção entre tais fatores pode ser observada nos casos a seguir. 
Nível I na categoria relações com a regra e nível III em ações no jogar (1RX3A)

Figura 12 - Gráfico de acompanhamento individual do sujeito 06 (TAL).

\begin{tabular}{|c|c|c|c|c|c|c|c|c|c|c|c|c|c|c|c|c|c|c|c|c|c|c|c|}
\hline $\mathbf{S}$ & $\mathbf{N}$ & $\mathbf{L}$ & L1 & L2 & $\underline{\mathbf{L 3}}$ & $\underline{\mathbf{U}}$ & U1 & U2 & U3 & $\mathbf{S}$ & S1 & $\mathbf{S 2}$ & S3 & $\mathbf{R}$ & R1 & R2 & $\mathbf{A}$ & A1 & A2 & $\mathbf{P}$ & P1 & $\mathbf{P 2}$ & $\mathbf{E}$ \\
\hline \multirow{3}{*}{$\begin{array}{c}6 . \\
\text { TAL }\end{array}$} & I & • & • & • & • & $\bullet$ & • & - & $\bullet$ & & & & & - & - & & & & & - & • & • & \\
\hline & II & & & & & & & & & & & & & & & & & & & & & & • \\
\hline & III & & & & & $\bullet$ & & & & $\bullet$ & • & • & • & & & • & • & $\bullet$ & • & & & & \\
\hline
\end{tabular}

Figura 13 - Gráfico de acompanhamento individual do sujeito 43 (SAR).

\begin{tabular}{|c|c|c|c|c|c|c|c|c|c|c|c|c|c|c|c|c|c|c|c|c|c|c|c|}
\hline $\mathbf{S}$ & $\mathbf{N}$ & $\mathbf{L}$ & L1 & L2 & $\mathbf{L 3}$ & $\mathbf{U}$ & $\mathrm{U} 1$ & U2 & U3 & $\mathbf{S}$ & S1 & S2 & $\mathbf{S 3}$ & $\mathbf{R}$ & R1 & R2 & $\mathbf{A}$ & A1 & $\mathrm{A2}$ & $\mathbf{P}$ & P1 & $\mathbf{P 2}$ & $\mathbf{E}$ \\
\hline \multirow{3}{*}{$\begin{array}{l}43 . \\
\text { SAR }\end{array}$} & I & & & & & & & & & & & & & $\bullet$ & • & • & & & & & & & \\
\hline & II & & & & & & & & & & $\bullet$ & & $\bullet$ & & & & & & & & & & \\
\hline & III & - & $\bullet$ & • & • & • & • & $\bullet$ & • & $\bullet$ & & • & & & • & & • & $\bullet$ & $\bullet$ & • & • & • & • \\
\hline
\end{tabular}

Seguindo a mesma linha de análise, vemos que TAL e SAR manifestam diferentes particularidades, apesar de sua mesma classificação. Ambos possuem baixo rendimento na categoria relações com as regras e se destacam em suas ações no jogo, porém, TAL o faz no contexto aberto enquanto que SAR apresenta oscilações neste contexto segundo os critérios de relevância em um ou noutro fator. Ainda assim, se observa maiores avanços em SAR.

Disto ponderam-se dois fatos. Primeiro, que uma boa atuação no contexto aberto nem sempre reflete um real avanço na tomada de consciência da natureza da regra, podendo ficar restrita a uma prática mecanizada sem muito teor relacional (tanto que o bom desempenho de TAL nas ações não vem acompanhado de boas atuações com pessoas neste contexto). Muito pelo contrário, em alguns casos a dificuldade de atuar na ausência de referências precisas que coloquem todos sob a mesma égide pode sugerir um maior entendimento do caráter social da regra. Em segundo lugar, vemos que a oportunidade de legislar e efetivar trocas igualitárias por si só, pouco adianta quando não subsidiada pela capacidade de se posicionar frente aos outros com base na 
reciprocidade, isto é, sem a devida tomada de consciência individual a respeito dessas condições.

Pudemos refletir com as intersecções até aqui analisadas a respeito dos fatores associados a uma conduta interpretativa da regra, vimos que tal conduta pode tomar diferentes feições a depender dos tipos de interações e intenções em jogo. A nosso ver ficaram patentes pelo menos três destas diferentes feições: uma meramente pragmática, quando se usa a regra somente para se atingir um objetivo (como ganhar o jogo, por exemplo); outra com fins unicamente adaptativos, no caso de um conformismo à regra como instrumento de pura adequação ou subserviência e uma terceira, mais avançada em termos de nossos pressupostos teóricos, que busca na regra uma via de relação interpessoal pautada na reciprocidade.

Finda a discussão sobre os tipos de usos e desusos da regra apresentados por nossos sujeitos, é chegada a hora de acompanharmos, mais diretamente, como esses se deram a partir das diferentes nuances contextuais efetuadas.

\subsection{2- Por situações concretas de jogo:}

Passaremos agora à discussão de como se deu a evolução dos sujeitos nas diferentes situações de jogo propostas. Conforme exposto anteriormente a situação intermediária (Uno) não apresentou especificidades significativas ao nosso estudo, por isto nos limitaremos a contrapor os contextos fechado (Ludo) e aberto a partir da análise da Tabela 05 apresentada a seguir. Como forma de detectar diferentes reações e manifestações ao modo de estruturação das regras, daremos continuidade a apresentação e comparação de casos. 
Tabela 05 - Distribuição das crianças em níveis quanto à situação fechada e situação aberta

\begin{tabular}{|c|c|c|c|c|}
\hline $\mathbf{S}$ & NI & NII & NIII & Total \\
\hline NI & $\begin{array}{c}05 \\
(10,86)\end{array}$ & $\begin{array}{c}01 \\
(2,17)\end{array}$ & $\begin{array}{c}01 \\
(2,17)\end{array}$ & 07 \\
\hline NII & $\begin{array}{c}02 \\
(4,34)\end{array}$ & $\begin{array}{c}00 \\
(00)\end{array}$ & $\begin{array}{c}01 \\
(2,17)\end{array}$ & 03 \\
\hline NIII & $\begin{array}{c}23 \\
(50)\end{array}$ & $\begin{array}{c}00 \\
(00)\end{array}$ & $\begin{array}{c}13 \\
(28,26)\end{array}$ & 36 \\
\hline Total & 30 & 01 & 15 & 46 \\
\hline
\end{tabular}

L= Situação Fechada (Ludo).

$\mathrm{S}=$ Situação Aberta (Protocolo próprio)

$\mathrm{NI}=$ soma das frequências dos indicadores $01,04,11,13,15,16$ e 17.

$\mathrm{NII}=$ soma das frequências dos indicadores 02, 06, 05, 09, 18,19 e 20.

NIII = soma das frequências dos indicadores 03, 07, 08, 10, 12, 14, 21e 22 .

Obs: Foi utilizada a soma absoluta, sem utilizar critérios de distribuição de importância entre os fatores avaliados. Os valores entre parênteses expressam a porcentagem.

Como pode ser verificado, nossa amostra ficou em grande parte situada no nível I com relação à situação fechada e no nível III com relação à situação aberta (50 \%). Donde podemos extrair indícios relevantes de que uma maior abertura a trocas interindividuais e oportunidades de expressão podem vir a ser condizentes a um melhor entendimento do status coletivo da regra. Embora menos significativo, o índice de sujeitos que alcançaram o nível III nos dois contextos $(28,26 \%)$, evidencia que a consciência da regra pode prevalecer para uma parte das crianças independentemente das configurações contextuais dadas. Ambos os fatos podem ser acompanhados e melhor detalhados pelos casos que se seguem.

Nivel I na situação fechada e Nivel III na situação aberta (1LX3S)

Figura 14 - Gráfico de acompanhamento individual do sujeito 21 (ANA).

\begin{tabular}{|c|c|c|c|c|c|c|c|c|c|c|c|c|c|c|c|c|c|c|c|c|c|c|c|}
\hline $\mathbf{S}$ & $\mathbf{N}$ & $\mathbf{L}$ & L1 & L2 & L3 & $\mathbf{U}$ & U1 & U2 & U3 & $\mathbf{S}$ & S1 & S2 & S3 & $\mathbf{R}$ & R1 & $\mathbf{R 2}$ & A & A1 & A2 & $\mathbf{P}$ & P1 & P2 & $\mathbf{E}$ \\
\hline \multirow{3}{*}{$\begin{array}{l}21 . \\
\text { ANA }\end{array}$} & I & - & • & - & - & • & - & - & • & & & & & & & & & & & - & - & - & - \\
\hline & II & & - & & & & & & & & & & & • & $\bullet$ & $\bullet$ & & & & & & & \\
\hline & III & & & & & & & & & • & $\bullet$ & • & $\bullet$ & & & & - & - & $\bullet$ & & & & \\
\hline
\end{tabular}


Figura 15 - Gráfico de acompanhamento individual do sujeito 52 (ANA).

\begin{tabular}{|c|c|c|c|c|c|c|c|c|c|c|c|c|c|c|c|c|c|c|c|c|c|c|c|}
\hline $\mathbf{S}$ & $\mathbf{N}$ & $\mathbf{L}$ & L1 & L2 & L3 & $\mathbf{U}$ & U1 & $\mathbf{U 2}$ & U3 & $\mathbf{S}$ & S1 & $\mathbf{S 2}$ & S3 & $\mathbf{R}$ & R1 & R2 & $\mathbf{A}$ & A1 & A2 & $\mathbf{P}$ & P1 & $\mathbf{P 2}$ & $\mathbf{E}$ \\
\hline \multirow{3}{*}{$\begin{array}{c}52 . \\
\text { ANA }\end{array}$} & I & - & • & • & • & • & • & • & • & & & & & • & • & • & • & - & • & & • & & • \\
\hline & II & & & & & & & & & & & & & & & & & & & & & & \\
\hline & III & & & & & & & & & • & • & • & - & & & & & & & - & & • & \\
\hline
\end{tabular}

Figura 16 - Gráfico de acompanhamento individual do sujeito 22 (GAB).

\begin{tabular}{|c|c|c|c|c|c|c|c|c|c|c|c|c|c|c|c|c|c|c|c|c|c|c|c|}
\hline $\mathbf{S}$ & $\mathbf{N}$ & $\mathbf{L}$ & L1 & L2 & L3 & $\mathbf{U}$ & U1 & U2 & $\mathbf{U 3}$ & $\mathbf{S}$ & S1 & $\mathbf{S 2}$ & S3 & $\mathbf{R}$ & R1 & R2 & $\mathbf{A}$ & A1 & A2 & $\mathbf{P}$ & P1 & P2 & $\mathbf{E}$ \\
\hline \multirow{3}{*}{$\begin{array}{c}22 . \\
\text { GAB }\end{array}$} & I & - & $\bullet$ & $\bullet$ & $\bullet$ & & & & & & & & & & & & $\bullet$ & $\bullet$ & $\bullet$ & $\bullet$ & $\bullet$ & $\bullet$ & \\
\hline & II & & & & & & & & & & & & & & & & & & & & & & \\
\hline & III & & & & & • & • & $\bullet$ & • & • & • & $\bullet$ & $\bullet$ & $\bullet$ & $\bullet$ & • & & & & & & & $\bullet$ \\
\hline
\end{tabular}

Tomando em conjunto os três casos acima expostos, vemos que os avanços no contexto aberto encobrem particularidades diversas. Em primeiro plano, destaca-se que os resultados de cada sujeito se referem a categorias distintas, GAB foi melhor em R, já para $\operatorname{ANA}(52)$ o $\mathrm{P}$ foi mais incidente, enquanto que para $\mathrm{ANA}(21)$ o A prevaleceu. Nota-se, contudo, que os avanços de GAB e ANA(52) foram mais isolados que os de ANA(21), cujo progresso também se evidenciou em R, ainda que medianamente. Sobre isto, aliás, julga-se pertinente apresentar maiores informações, provenientes da amostra como um todo.

Dos 23 sujeitos que obtiveram avanços da situação fechada para a aberta, somente $04(17,4 \%)$ o fizeram para as três categorias conjuntamente; $05(21,7 \%)$ se destacaram em uma delas especificamente (02 em R, 02 em A e 01 em P) e $14(60,9 \%)$ tiveram seus resultados compartilhados em duas categorias. Destes, 06 se destacaram para regras e ações no jogar, 03 para regras e pessoas e 05 para ações e pessoas. Reorganizando-se tais dados, temos que a relação com a regra esteve presente em 65,2\% dos casos (15 em 23), as ações no jogar compareceu em 73,9\% deles (17 em 23) 
e as relações entre pessoas em 56,5\% (13 em 23). ${ }^{11}$ Donde surgem algumas constatações.

Em primeiro lugar, parece que, para estes sujeitos, o ambiente cooperativo foi assimilado mais em termos de suas semelhanças com os demais (o fato de ser também um jogo) do que exatamente por conta de suas peculiaridades principais, ou seja, a possibilidade de atuar com base na reciprocidade, buscando igualdade nas relações e acordos consensuais a respeito das regras. Considerando ainda estas duas peculiaridades, vemos que a interação com a regra se sobressaiu em relação às trocas interindividuais. Ambos os fatos levantados por nossos dados, podem ser explicados pela própria idade das crianças que, segundo a abordagem piagetiana, se encontram transitoriamente em uma condição ainda um pouco heterônoma e não completamente autônoma, portanto, sem efetiva consolidação da capacidade de cooperar.

A parte tal transitoriedade, foi possível observar, em alguns sujeitos, certo desprendimento do contexto e manutenção de posturas mais autônomas em todas as situações colocadas. É o que discutiremos em seguida.

\section{Nível III em ambos (3LX3S)}

Figura 17 - Gráfico de acompanhamento individual do sujeito 40 (ERI).

\begin{tabular}{|c|c|c|c|c|c|c|c|c|c|c|c|c|c|c|c|c|c|c|c|c|c|c|c|}
\hline S & N & L & L1 & L2 & L3 & U & U1 & U2 & U3 & S & S1 & S2 & S3 & R & R1 & R2 & A & A1 & A2 & P & P1 & P2 & E \\
\hline \multirow{2}{*}{$\begin{array}{c}\text { 40. } \\
\text { ERI }\end{array}$} & I & & & & & & & & & & & & & & & & & & & & & & \\
\cline { 2 - 16 } & II & & & & & & & & & & & & & & & & & & & & & $\bullet$ \\
\hline
\end{tabular}

Figura 18 - Gráfico de acompanhamento individual do sujeito 10 (REN).

\begin{tabular}{|c|c|c|c|c|c|c|c|c|c|c|c|c|c|c|c|c|c|c|c|c|c|c|c|}
\hline $\mathbf{S}$ & $\mathbf{N}$ & $\mathbf{L}$ & L1 & $\mathrm{L} 2$ & L3 & $\mathbf{U}$ & U1 & U2 & U3 & $\mathbf{S}$ & S1 & S2 & S3 & $\mathbf{R}$ & R1 & R2 & $\mathbf{A}$ & A1 & A2 & $\mathbf{P}$ & P1 & $\mathbf{P 2}$ & $\mathbf{E}$ \\
\hline \multirow{3}{*}{$\begin{array}{c}10 . \\
\text { REN }\end{array}$} & I & & & & & & & & & & & & & • & • & • & & & & & $\bullet$ & & \\
\hline & II & & & & & & & & & & & & & & & & & & & & & & • \\
\hline & III & • & • & • & • & • & • & • & • & - & • & • & • & • & • & • & • & • & • & • & & • & \\
\hline
\end{tabular}

\footnotetext{
${ }^{11}$ Dados sistematizados a partir das planilhas de tabulação geral, contidas em CD-ROM (Anexo 03).
} 
Figura 19 - Gráfico de acompanhamento individual do sujeito 09 (CLA).

\begin{tabular}{|c|c|c|c|c|c|c|c|c|c|c|c|c|c|c|c|c|c|c|c|c|c|c|c|}
\hline $\mathbf{S}$ & $\mathbf{N}$ & $\mathbf{L}$ & L1 & L2 & $\mathbf{L 3}$ & $\mathbf{U}$ & U1 & U2 & U3 & $\mathbf{S}$ & S1 & S2 & S3 & $\mathbf{R}$ & R1 & R2 & $\mathbf{A}$ & A1 & A2 & $\mathbf{P}$ & P1 & P2 & $\mathbf{E}$ \\
\hline \multirow{3}{*}{$\begin{array}{c}9 . \\
\text { CLA }\end{array}$} & I & & & & & • & • & • & • & & & & & & & & & & & & & & \\
\hline & II & & & & & & & & & & & & & & & & & & & & & & \\
\hline & III & • & • & • & • & • & • & • & • & - & • & • & • & • & • & • & • & • & • & • & • & • & • \\
\hline
\end{tabular}

A articulação entre os três casos nos permite constatações que reforçam as discussões apresentadas no tópico anterior. Aqui, mais uma vez, encontramos algumas singularidades que ficam encobertas na classificação geral. Por isso, após os comentários dos casos selecionados veremos como ficou a distribuição das categorias para este grupo como um todo, de forma semelhante ao que fizemos logo acima.

Com relação aos casos, temos em primeiro lugar (ERI) um exemplo típico de estabilidade frente às diversas situações, ocorrendo somente um leve desnível para a entrevista, que pode ser explicado por características próprias a esta situação vinculadas ao fator etário (além da entrevista exigir habilidades diferenciadas que serão discutidas posteriormente, ERI é uma das crianças mais novas da amostra, com 07 anos e meio). CLA também demonstra relativa estabilidade, apesar da diminuição de seu rendimento na situação intermediária, que não repercutiu incisivamente em nenhuma de suas manifestações quanto às categorias propostas. Dentre os casos que sofreram maiores alterações, destaca-se o de REN que além de não se estabelecer efetivamente no NIII no que se refera às regras, possui pior desempenho na situação fechada no quesito relação com as pessoas (vide seu P1).

Se tomarmos em consideração o grupo todo, veremos que dos 13 sujeitos que se estabeleceram no nível III para ambas as situações avaliadas, $07(53,8 \%)$ o fazem para as três categorias, somente $01(7,7 \%)$ o faz para uma única categoria (ações no jogar) e $05(38,5 \%)$ se destacam em duas categorias concomitantemente $(02 \mathrm{R} / \mathrm{A}, 01 \mathrm{R} / \mathrm{P}$ e 02 A/P). Desta forma, foi possível verificar que uma maior estabilidade frente às nuances contextuais vem acompanha por relativa correspondência entre os três aspectos 
avaliados. Embora, a ação entre jogar ainda apareça com certa predominância (12 em 13 casos), a relação com a regra e relação entre pessoas encontram-se mais fortemente associadas e presentes (10 em 13 casos, cada uma), sugerindo mesmo, a generalização dos esquemas construídos, o que aliás se mostra extremamente compatível com nossos pressupostos teóricos.

Após discussão de como se deu a relação com a regra do jogo em contextos concretos, passemos a análise de sua contraposição com a forma de conceber a regra moral em contextos hipotéticos de jogo e de situações cotidianas.

\subsection{3- Pela comparação entre situações reais e hipotéticas:}

Neste ponto de nossa exposição realizaremos alguns cruzamentos entre os dados obtidos por meio das situações de jogo concretas com as concepções das crianças enunciadas na situação hipotética. A ideia é estabelecer comparativamente diferenças e semelhanças nas formas de lidar com a regra do jogo em si e a regra moral vivenciada no jogo e no cotidiano. Como já exposto, a primeira foi investigada por meio de ações concretas manifestadas nas três situações de jogo e a segunda o foi a partir dos juízos emitidos frente às estórias-dilemas colocadas na entrevista. Importante se faz notificar que, para melhor visualização dos dados, o NII para a situação hipotética foi dividido em NII A (13,5 a 17 pontos) e NII B (17,5 a 20,5 pontos), uma vez que devido à idade das crianças houve grande concentração da amostra neste nível, não refletindo suas reais singularidades quando tomadas em um único bloco.

Apresentaremos, primeiramente, uma análise que reúne os dados da situação aberta, da situação fechada e das entrevistas. Depois faremos a intersecção entre a 
situação hipotética e a categoria relações com a regra especificamente. Para nossa primeira proposição, usaremos conjuntamente os dados das Tabelas 06 e 07 a seguir:

Tabela 06 - Distribuição das crianças em níveis quanto à situação fechada e situação hipotética

\begin{tabular}{|c|c|c|c|c|}
\hline E & NI & NII & NIII & Total \\
\hline NI & $\begin{array}{c}05 \\
(10,2)\end{array}$ & $\begin{array}{c}00 \\
(00)\end{array}$ & $\begin{array}{c}00 \\
(00)\end{array}$ & 05 \\
\hline NII A & $\begin{array}{c}06 \\
(12,24)\end{array}$ & $\begin{array}{c}02 \\
(4,08)\end{array}$ & $\begin{array}{c}03 \\
(6,12)\end{array}$ & 11 \\
\hline NII B & $\begin{array}{c}09 \\
(18,36)\end{array}$ & $\begin{array}{c}00 \\
(00)\end{array}$ & $\begin{array}{c}10 \\
(24,4 \%)\end{array}$ & 19 \\
\hline NIII & $\begin{array}{c}10 \\
(20,4)\end{array}$ & $\begin{array}{c}00 \\
(00)\end{array}$ & $\begin{array}{c}04 \\
(8,16)\end{array}$ & 14 \\
\hline Total & 30 & 02 & 17 & 49 \\
\hline
\end{tabular}

\section{Legenda:}

L= Situação Fechada (Ludo).

$\mathrm{E}=$ Situação Hipotética (Entrevista)

$\mathrm{NI}=$ soma das frequências dos indicadores $01,04,11,13,15,16$ e 17 para situação fechada e escore de 06 a 13 pontos para a situação hipotética.

$\mathrm{NII}=$ soma das frequências dos indicadores $02,06,05,09,18,19$ e 20 para situação fechada e escore de 13,5 a 20,5 pontos para a situação hipotética.

NIII = soma das frequências dos indicadores $03,07,08,10,12,14,21 \mathrm{e} 22$ para situação fechada e escore de $21 \mathrm{a}$ 28 pontos para a situação hipotética.

Obs: Foi utilizada a soma absoluta, sem utilizar critérios de distribuição de importância entre os fatores avaliados. Os valores entre parênteses expressam a porcentagem.

Tabela 07 - Distribuição das crianças em níveis quanto à situação aberta e situação hipotética

\begin{tabular}{|c|c|c|c|c|}
\hline $\mathbf{E}$ & $\mathbf{N I}$ & NII & NIII & Total \\
\hline NI & $\begin{array}{c}01 \\
(2,27)\end{array}$ & $\begin{array}{c}00 \\
(00)\end{array}$ & $\begin{array}{c}02 \\
(4,54)\end{array}$ & 03 \\
\hline NII A & $\begin{array}{c}01 \\
(4,54)\end{array}$ & $\begin{array}{c}03 \\
(6,81)\end{array}$ & $\begin{array}{c}08 \\
(18,2)\end{array}$ & 27 \\
\hline NII B & $\begin{array}{c}01 \\
(2,27)\end{array}$ & $\begin{array}{c}00 \\
(00)\end{array}$ & $\begin{array}{c}14 \\
(31,8)\end{array}$ & 15 \\
\hline NIII & $\begin{array}{c}01 \\
(2,27)\end{array}$ & $\begin{array}{c}01 \\
(2,27)\end{array}$ & $\begin{array}{c}12 \\
(27,3)\end{array}$ & 14 \\
\hline Total & 04 & 04 & 36 & 44 \\
\hline
\end{tabular}

$\mathrm{S}=$ Situação Aberta (Protocolo próprio).

Legenda:

$\mathrm{E}=$ Situação Hipotética (Entrevista)

$\mathrm{NI}=$ soma das frequências dos indicadores $01,04,11,13,15,16$ e 17 para situação aberta e escore de 06 a 13 pontos para a situação hipotética.

$\mathrm{NII}=$ soma das frequências dos indicadores $02,06,05,09,18,19$ e 20 para situação aberta e escore de 13,5 a 20,5 
pontos para a situação hipotética.

NIII = soma das frequências dos indicadores $03,07,08,10,12,14,21$ e 22 para situação aberta e escore de 21 a 28 pontos para a situação hipotética.

Obs: Foi utilizada a soma absoluta, sem utilizar critérios de distribuição de importância entre os fatores avaliados. Os valores entre parênteses expressam a porcentagem.

Como se verifica pelas tabelas, há aparentemente maior correspondência no cruzamento da situação hipotética com a situação aberta, do que daquela com a situação fechada. Colocando em números, vemos que das 36 crianças que atingiram o NIII na situação aberta, 26 (72,2\%) estão ou no nível II B (14 - 38,8\%) ou no nível III (12 33,3\%) para a situação hipotética. Quando comparada ao contexto fechado, temos que o bom desempenho no contexto hipotético (NII B e NIII somados) foi obtido tanto por crianças de nível I (19 em 33 - 57,6\%) quanto por crianças de nível III (14 em 33 42,4\%), denotando maior desarticulação entre eles. Isto aponta, de uma maneira geral, diferenças entre o que as crianças fazem e julgam quanto às suas experiências reais e o que pensam de forma abstrata. Todavia a situação aberta, justamente por contemplar mais aspectos interacionais do que a situação fechada e com isso permitir maior oportunidades de reflexão sobre a regra, se mostrou mais propícia a articulação, do ponto de vista das crianças, entre o que foi feito (e pensado) no momento da experiência e seus julgamentos para as situações hipotéticas.

Cabe ainda ponderarmos que uma atuação menos desejável no contexto fechado, seguida de boa atuação no contexto aberto pode ser, dependendo do caso, mais sugestiva de avanços na capacidade de refletir sobre a regra, do que uma estabilidade absoluta, sendo inclusive mais condizente com a capacidade de pensar a regra hipoteticamente. Considerando os dados provenientes da amostra como um todo, vemos que, dos 15 sujeitos classificados no nível três para a situação hipotética, 09 (60\%) se enquadram neste padrão (1LX3S). Dos 06 restantes, 03 se classificaram no nível três para ambos os contextos (3LX3S), 01 ficou no nível I e 01 no nível II também para 
ambas as situações (1LX1S e 2LX2S), o sujeito restante não participou da situação aberta. Tal padrão se repete, ainda que de forma menos prevalente, para o NII B da situação hipotética, onde a maior frequência foi para sujeitos nele situados (08 em 23 $34,8 \%$ ). Os demais se distribuíram em padrões variados, sendo que 05 deles $(21,7 \%)$ apresentaram constância. Eis os casos:

Correspondência absoluta entre situação concreta e situação hipotética (3L/3S X $\underline{2 b / 3 E):}$

Figura 20 - Gráfico de acompanhamento individual do sujeito 39 (LUI).

\begin{tabular}{|c|c|c|c|c|c|c|c|c|c|c|c|c|c|c|c|c|c|c|c|c|c|c|c|}
\hline $\mathbf{S}$ & $\mathbf{N}$ & $\mathbf{L}$ & L1 & L2 & $\mathbf{L 3}$ & $\mathbf{U}$ & $\mathbf{U 1}$ & U2 & U3 & $\mathbf{S}$ & S1 & S2 & S3 & $\mathbf{R}$ & R1 & $\mathbf{R 2}$ & \begin{tabular}{l|l}
$\mathbf{A}$ \\
\end{tabular} & A1 & $\mathbf{A 2}$ & $\mathbf{P}$ & P1 & P2 & $\mathbf{E}$ \\
\hline \multirow{3}{*}{$\begin{array}{c}39 . \\
\text { LUI }\end{array}$} & I & & & & & & & & & & & & & & & & & & & & & & \\
\hline & II & & & & & & & & & & - & & - & & & & & & & & & & 1 \\
\hline & III & - & • & - & - & - & • & • & - & - & & - & & - & - & • & - & - & - & - & • & - & \\
\hline
\end{tabular}

Figura 21 - Gráfico de acompanhamento individual do sujeito 15 (ENZ).

\begin{tabular}{|c|c|c|c|c|c|c|c|c|c|c|c|c|c|c|c|c|c|c|c|c|c|c|c|}
\hline $\mathbf{S}$ & $\mathbf{N}$ & $\mathbf{L}$ & L1 & L2 & L3 & $\mathbf{U}$ & U1 & U2 & U3 & S & S1 & S2 & S3 & $\mathbf{R}$ & R1 & R2 & $\mathbf{A}$ & A1 & A2 & $\mathbf{P}$ & P1 & P2 & $\mathbf{E}$ \\
\hline \multirow{3}{*}{$\begin{array}{c}15 . \\
\text { ENZ }\end{array}$} & I & & & & & & & & & & & & & & & & & & & & & & \\
\hline & II & & & & & & & & & & & & & & & & & & & & & & \\
\hline & III & - & - & • & • & • & - & • & • & • & • & • & - & • & - & - & • & • & - & - & - & • & • \\
\hline
\end{tabular}

Pela comparação entre as duas trajetórias apresentadas verificamos que, mesmo em meio a constância de resultados entre as três situações, surgem especificidades dignas de nota, como é o caso de LUI que demonstra variações justamente na situação aberta e, coincidentemente ou não, menor capacidade de teorizar a respeito da regra do que ENZ, cuja estabilidade se deu de forma contínua. Como discutido anteriormente tal permanência absoluta pode ser tão positiva, em termos teóricos, quanto a demonstração de um desempenho ruim na situação fechada, acompanhado de avanços na situação aberta e situação hipotética. Supõe-se assim que a dificuldade em lidar com regras impostas atrelada a bons resultados em contextos de maior flexibilização (seja pela via 
das ações ou das ideias) pode também ser indicativa de uma relação com a regra impregnada de, senão maior autonomia, pelo menos maior versatilidade. Passemos a análise dos casos.

Coerência relativa entre situação concreta e situação hipotética ( $1 L$ X $3 S$ X 2b/3E):

Figura 22 - Gráfico de acompanhamento individual do sujeito 54 (MAR).

\begin{tabular}{|c|c|c|c|c|c|c|c|c|c|c|c|c|c|c|c|c|c|c|c|c|c|c|c|}
\hline S & $\mathbf{N}$ & $\mathbf{L}$ & L1 & L2 & $\mathbf{L 3}$ & $\underline{\mathbf{U}}$ & U1 & $\mathrm{U} 2$ & U3 & $\mathbf{S}$ & $\underline{\text { S1 }}$ & S2 & S3 & $\mathbf{R}$ & R1 & R2 & $\mathbf{A}$ & A1 & $\mathrm{A2}$ & $\mathbf{P}$ & P1 & $\mathbf{P 2}$ & $\mathbf{E}$ \\
\hline \multirow{3}{*}{$\begin{array}{c}54 . \\
\text { MAR }\end{array}$} & I & • & • & $\bullet$ & $\bullet$ & & & & & & & & & & $\bullet$ & & & & & - & $\bullet$ & & \\
\hline & II & & & & & • & • & - & • & & & & & & & & & & & & & & \\
\hline & III & & & & & & & & & • & $\bullet$ & $\bullet$ & • & • & & • & $\bullet$ & - & • & - & & • & - \\
\hline
\end{tabular}

Figura 23 - Gráfico de acompanhamento individual do sujeito 23 (CAR).

\begin{tabular}{|c|c|c|c|c|c|c|c|c|c|c|c|c|c|c|c|c|c|c|c|c|c|c|c|}
\hline $\mathbf{S}$ & $\mathbf{N}$ & $\mathbf{L}$ & L1 & L2 & L3 & $\mathbf{U}$ & U1 & $\mathbf{U 2}$ & U3 & $\mathbf{S}$ & S1 & $\mathbf{S 2}$ & S3 & $\mathbf{R}$ & R1 & $\mathbf{R 2}$ & $\mathbf{A}$ & $\mathbf{A 1}$ & A2 & $\mathbf{P}$ & P1 & P2 & $\mathbf{E}$ \\
\hline \multirow{3}{*}{$\begin{array}{c}23 . \\
\text { CAR }\end{array}$} & I & • & - & • & - & & & & & & & & & • & - & & & & & & & & \\
\hline & II & & & & & & & & & & & & & • & & • & & & & & & & \\
\hline & III & & & & & • & • & • & • & • & • & • & • & • & & & • & • & • & - & • & • & - \\
\hline
\end{tabular}

Figura 24 - Gráfico de acompanhamento individual do sujeito 63 (EST).

\begin{tabular}{|c|c|c|c|c|c|c|c|c|c|c|c|c|c|c|c|c|c|c|c|c|c|c|c|}
\hline $\mathbf{S}$ & $\mathbf{N}$ & $\mathbf{L}$ & L1 & L2 & L3 & $\mathbf{U}$ & U1 & U2 & U3 & $\mathbf{S}$ & S1 & S2 & $\mathbf{S 3}$ & $\mathbf{R}$ & R1 & $\mathbf{R 2}$ & $\mathbf{A}$ & A1 & A2 & $\mathbf{P}$ & P1 & P2 & $\mathbf{E}$ \\
\hline \multirow{3}{*}{$\begin{array}{c}63 . \\
\text { EST }\end{array}$} & I & - & & • & • & • & & & & & & & & & & & - & • & & • & • & • & \\
\hline & II & & • & & & & & & & & • & & & • & • & - & & & & & & & $/$ \\
\hline & III & & & & & • & • & • & • & - & & • & • & & & & • & & • & & & & \\
\hline
\end{tabular}

Novamente verificamos interessantes especificidades nas trajetórias individuais de sujeitos com classificação semelhante. Vemos, por exemplo, que MAR apresenta uma verdadeira progressão no decorrer das três situações concretas que culmina em um bom resultado também na situação hipotética. CAR obtém avanços um pouco antes, já na situação intermediária, atingindo, igualmente, o NIII para a situação hipotética. Um ponto de diferenciação entre eles é que, fora a concordância na categoria ações no jogar, as manifestações gerais de cada um no jogo encontram-se, para MAR, mais ligadas às regras e, para CAR, mais associadas às pessoas (vide os R's e os P's de cada gráfico), o que talvez também explique suas diferenças quanto a situação intermediária. EST, por 
sua vez, apresenta-se oscilante nas situações concretas segundo os diferentes critérios de análise, demonstrando inclusive índices de medianos a ruins nas três categorias. Seu A2, por exemplo, nos indica que seus avanços na situação aberta se deram mais devido às ações no jogar do que à regra em si. Tais características, aliás, repercutem, por acaso ou não, no resultado da situação hipotética.

Foram debatidas até o momento as possíveis similitudes e assimetrias entre os contextos concretos e hipotéticos de nosso estudo, no que diz respeito às condutas e concepções apresentadas por nossos sujeitos de forma geral. Vejamos agora o que acontece quando consideramos de forma mais específica a relação com a regra, conforme exposto na Tabela $\mathbf{0 8 .}$

Tabela 08 - Distribuição das crianças em níveis quanto à categoria relações com a regra e a situação hipotética

\begin{tabular}{|c|c|c|c|c|}
\hline E & NI & NII & NIII & Total \\
\hline NI & $\begin{array}{c}03 \\
(06)\end{array}$ & $\begin{array}{c}02 \\
(04)\end{array}$ & $\begin{array}{c}00 \\
(00)\end{array}$ & 05 \\
\hline NII A & $\begin{array}{c}04 \\
(08)\end{array}$ & $\begin{array}{c}02 \\
(04)\end{array}$ & $\begin{array}{c}03 \\
(06)\end{array}$ & 09 \\
\hline NII B & $\begin{array}{c}05 \\
(10)\end{array}$ & $\begin{array}{c}06 \\
(12)\end{array}$ & $\begin{array}{c}11 \\
(22)\end{array}$ & 22 \\
\hline NIII & 04 & 05 & 05 & 14 \\
\hline Total & 16 & $15)$ & $(10)$ & 19 \\
\hline
\end{tabular}

$\mathrm{R}=$ Categoria relações com a regra.

$\mathrm{E}=$ Situação hipotética entrevista.

$\mathrm{NI}=$ soma das frequências dos indicadores 01 e 04 para $\mathrm{R}$ e escore de 06 a 13 pontos para a situação hipotética.

$\mathrm{NII}=$ soma das frequências dos indicadores 02,06 e 05 para R e escore de 13,5 a 20,5 pontos para a situação hipotética.

NIII = soma das frequências dos indicadores 03,07 e 08 para R e escore de 21 a 28 pontos para a situação hipotética.

Obs: Foi utilizada a soma absoluta, sem utilizar critérios de distribuição de importância entre os fatores avaliados. Os valores entre parênteses expressam a porcentagem.

Interessante notar que houve, até certo ponto, uniformidade na distribuição da amostra, pois, com exceção do intervalo de maior frequência, tivemos pouca ou quase nenhuma aglomeração expressiva (grande parte dos índices se repetem por duas ou mais vezes em intervalos distintos). A primeira vista, portanto, não temos indícios 
significativos a respeito das relações entre a consciência da regra manifestada concretamente e a compreensão da mesma em situação fictícia.

Contudo, é relevante o fato de que dos 36 sujeitos que apresentaram bons resultados na entrevista (NII B e NIII somados), 16 (44,4\%) também o fizeram para a categoria relações com a regra, sugerindo suposta compatibilidade entre tais quesitos. Argumento este, que pode ser fortalecido pela situação inversa, ou seja, dos 14 sujeitos com rendimento aquém do esperado na entrevista, 07 (50\%) mostraram-se igualmente pouco eficientes em sua relação com a regra nas situações concretas.

Cabe ressaltar, entretanto, a incidência de sujeitos que se posicionaram avançadamente frente às questões hipotéticas, mas que não tiveram bom desempenho na categoria relações com a regra (09 em 16 - 56,25\%), significando, portanto, que embora a consciência da regra conduza a uma boa capacidade de teorizar sobre a mesma, o inverso não ocorre, ou seja, adequadas teorizações sobre a regra não garantem seu uso de forma suficientemente interpretativa e consciente. A título de ilustração apresentamos abaixo dois casos para cada um dos padrões comentados:

\section{Níveis avançados em ambos ( $3 R X 2 b / 3 E)$}

Figura 25 - Gráfico de acompanhamento individual do sujeito 16 (HAL).

\begin{tabular}{|c|c|c|c|c|c|c|c|c|c|c|c|c|c|c|c|c|c|c|c|c|c|c|c|}
\hline $\mathbf{S}$ & $\mathbf{N}$ & $\mathbf{L}$ & L1 & $\mathrm{L2}$ & L3 & $\mathbf{U}$ & U1 & U2 & $\mathbf{U 3}$ & $\mathbf{S}$ & S1 & $\mathrm{S2}$ & S3 & $\mathbf{R}$ & R1 & $\mathrm{R} 2$ & $\mathbf{A}$ & A1 & A2 & $\mathbf{P}$ & P1 & P2 & $\mathbf{E}$ \\
\hline \multirow{3}{*}{$\begin{array}{c}16 . \\
\text { HAL }\end{array}$} & I & • & & • & & & & & & & & & & & & & & & & & & & \\
\hline & II & & & & & & & & & & & & & & & & & & & & & & \\
\hline & III & & • & & - & • & • & • & • & • & • & - & - & - & • & - & • & - & $\bullet$ & - & • & • & \\
\hline
\end{tabular}

Figura 26 - Gráfico de acompanhamento individual do sujeito 47 (MAR).

\begin{tabular}{|c|c|c|c|c|c|c|c|c|c|c|c|c|c|c|c|c|c|c|c|c|c|c|c|}
\hline $\mathbf{S}$ & $\mathbf{N}$ & $\mathbf{L}$ & L1 & L2 & $\mathbf{L 3}$ & $\mathbf{U}$ & U1 & U2 & U3 & $\mathbf{S}$ & S1 & $\mathbf{S 2}$ & S3 & $\mathbf{R}$ & R1 & $\mathbf{R 2}$ & $\mathbf{A}$ & A1 & A2 & $\mathbf{P}$ & P1 & P2 & $\mathbf{E}$ \\
\hline \multirow{3}{*}{$\begin{array}{l}47 . \\
\text { MAR }\end{array}$} & I & • & • & • & • & • & • & • & • & & & & & & & & & • & & & • & & \\
\hline & II & & & & & & & & & & & & & & & & & & & & • & & \\
\hline & III & & & & & & & & & • & • & - & • & • & • & • & • & • & • & - & • & • & - \\
\hline
\end{tabular}


Notadamente observa-se que a trajetória de MAR foi mais instável que a de HAL, porém tal instabilidade pode representar uma boa relação com a regra, uma vez que houve melhora na situação aberta e seu $\mathrm{R}$ está, juntamente com seu $\mathrm{P}$, bem classificado, encontrando congruência com a situação hipotética. Já HAL, embora persevere mais em sua estabilidade, alcançou um menor índice para esta situação, além de ter atuado com menor eficiência na situação fechada justamente na categoria relações com a regra, como nos mostra seu L2. Retifica-se, assim, a importância da análise individual comparativa como forma de apreendermos a multiplicidade de modulações inerentes ao fenômeno investigado. Isto posto, acompanhemos tais modulações para os casos de congruência em níveis menos avançados e, em seguida, para os casos demonstrativos de incompatibilidades.

\section{Desempenho ruim em ambos $(1 R \times 1 / 2 a E)$}

Figura 27 - Gráfico de acompanhamento individual do sujeito 18 (MAT).

\begin{tabular}{|c|c|c|c|c|c|c|c|c|c|c|c|c|c|c|c|c|c|c|c|c|c|c|c|}
\hline $\mathbf{S}$ & $\mathbf{N}$ & $\mathbf{L}$ & L1 & L2 & L3 & $\mathbf{U}$ & U1 & U2 & $\mathbf{U 3}$ & $\mathbf{S}$ & S1 & S2 & S3 & $\mathbf{R}$ & R1 & R2 & $\mathbf{A}$ & A1 & $\mathrm{A} 2$ & $\mathbf{P}$ & P1 & P2 & $\mathbf{E}$ \\
\hline \multirow{3}{*}{$\begin{array}{c}18 . \\
\text { MAT }\end{array}$} & I & - & - & • & • & $\bullet$ & • & - & - & & & & & - & $\bullet$ & - & & & & & & & - \\
\hline & II & & & & & & & & & $\phi$ & $\phi$ & $\phi$ & $\phi$ & & & & $\phi$ & $\phi$ & $\phi$ & & & & \\
\hline & III & & & & & & & & & & & & & & & & & & & - & • & $\bullet$ & \\
\hline
\end{tabular}

Figura 28 - Gráfico de acompanhamento individual do sujeito 29 (GAB).

\begin{tabular}{|c|c|c|c|c|c|c|c|c|c|c|c|c|c|c|c|c|c|c|c|c|c|c|c|}
\hline $\mathbf{S}$ & $\mathbf{N}$ & $\mathbf{L}$ & L1 & L2 & L3 & $\mathbf{U}$ & U1 & U2 & U3 & $S$ & S1 & S2 & S3 & $\mathbf{R}$ & R1 & $\mathbf{R 2}$ & $\mathbf{A}$ & A1 & A2 & $\mathbf{P}$ & P1 & P2 & $\mathbf{E}$ \\
\hline \multirow{3}{*}{$\begin{array}{c}29 . \\
\text { GAB }\end{array}$} & I & • & - & - & - & • & • & - & • & • & • & - & - & - & - & - & - & - & - & • & - & - & - \\
\hline & II & & & & & & & & & & & & & & & & & & & & & & \\
\hline & III & & & & & & & & & & & & & & & & & & & & & & \\
\hline
\end{tabular}

Aqui, mais uma vez, encontramos percursos, grosso modo iguais, mas que guardam interessantes informações. Basta-nos, a esta altura, apontar que o fato de MAT se destacar na categoria relações com as pessoas pode ser indicativo de leve avanço em relação à GAB, apesar de sua ausência de manifestações na situação aberta nos mostrar 
o oposto. Na verdade, ambos os casos, são alusivos de algo generalizável em nosso fenômeno, cuja manifestação, pelo visto, se molda mais pela capacidade assimilativa do sujeito do que necessariamente pela configuração dada as suas experiências, sejam elas concretas ou fictícias. É o que igualmente veremos para os casos que se seguem.

Desempenhos diferenciados para cada $(1 R \times 2 b / 3 E)$

Figura 29 - Gráfico de acompanhamento individual do sujeito 38 (ISA).

\begin{tabular}{|c|c|c|c|c|c|c|c|c|c|c|c|c|c|c|c|c|c|c|c|c|c|c|c|}
\hline $\mathbf{S}$ & $\mathbf{N}$ & $\mathbf{L}$ & L1 & L2 & L3 & $\mathbf{U}$ & $\mathrm{U1}$ & $\mathrm{U} 2$ & U3 & $\mathbf{S}$ & S1 & S2 & S3 & $\mathbf{R}$ & R1 & $\mathrm{R} 2$ & A & $\mathbf{A 1}$ & A2 & $\mathbf{P}$ & P1 & $\mathbf{P 2}$ & $\mathbf{E}$ \\
\hline \multirow{3}{*}{$\begin{array}{c}38 . \\
\text { ISA }\end{array}$} & I & • & • & • & • & - & • & - & • & • & & • & & - & • & • & • & • & • & • & $\bullet$ & • & \\
\hline & II & & & & & & & & & & • & & • & & & & & & & & & & \\
\hline & III & & & & & & & & & & & & & & & & & & & & & & \\
\hline
\end{tabular}

Figura 30 - Gráfico de acompanhamento individual do sujeito 05 (ANE).

\begin{tabular}{|c|c|c|c|c|c|c|c|c|c|c|c|c|c|c|c|c|c|c|c|c|c|c|c|}
\hline $\mathbf{S}$ & $\mathbf{N}$ & $\mathbf{L}$ & L1 & L2 & L3 & $\mathbf{U}$ & U1 & U2 & U3 & $\mathbf{S}$ & S1 & S2 & $\mathbf{S 3}$ & $\mathbf{R}$ & R1 & R2 & $\mathbf{A}$ & A1 & A2 & $\mathbf{P}$ & P1 & P2 & $\mathbf{E}$ \\
\hline \multirow{3}{*}{$\begin{array}{c}5 . \\
\text { ANE }\end{array}$} & I & • & • & • & • & $\bullet$ & • & - & • & & & & & - & - & - & & & & & & & \\
\hline & II & & & & & & & & & & & & & & & & & & & & & & \\
\hline & III & & & & & & & & & • & • & - & - & & & & • & - & - & - & • & - & • \\
\hline
\end{tabular}

Como exemplos que são da ocorrência de desarmonia entre os quesitos avaliados, ambos os casos expostos deixam claro que a possibilidade de conceber boas aplicações da regra em caráter fictício não garante a excelência de sua aplicabilidade em situações reais. As atuações de ISA são ainda mais incongruentes que as de ANE, pois não indicam avanços suficientemente elucidativos durante as situações concretas que, por ventura, possam ser relacionadas a seu relativo avanço na situação hipotética. Sobre isto cabe salientar que, embora busquemos em nossas análises conexões entre as atuações e concepções emitidas pelas crianças, devemos sempre ter em mente que temos em jogo regras de naturezas distintas, ou seja, o próprio fenômeno difere em seu conteúdo, mesmo que em tese exijam estruturações semelhantes. Seguindo a mesma linha de análise, vemos que o gráfico de ANE aponta uma menor incoerência, pois tem 
a seu favor avanços na situação aberta seguidos de boa classificação na categoria relações com as pessoas.

As análises empreendidas até aqui visaram apontar alguns matizes da relação com a regra em situações concretas e hipotéticas prescindindo de sua diferenciação em termos de conteúdos, ou seja, a regra do jogo e a regra moral foram postas momentaneamente em patamar de igualdade para que fossem discutidas suas variabilidades no que se refere às nuances contextuais. Vimos a respeito disto que, embora boas atuações no contexto aberto sejam congruentes com concepções mais avançadas na situação hipotética, estas nem sempre correspondem ao bom uso e interpretação da regra na experiência concreta.

Para o tópico seguinte focaremos exatamente a distinção entre regra do jogo e regra moral, nos debruçando sobre esta última. Visa-se, desta forma, discutir brevemente como nossos sujeitos avaliaram a contraposição entre a regra moral vivenciada no jogo e no cotidiano.

\section{3- Análise da regra associada a conteúdos morais}

Apresentaremos para nossa discussão os dados organizados de duas formas. Primeiramente avaliaremos qual dos conceitos avaliados apresentou maior coerência, ou seja, em qual deles foram obtidas as maiores pontuações. Depois analisaremos como cada um foi avaliado pelos sujeitos, classificando suas respostas em autônomas ou heterônomas, para o trecho da estória que retratava o jogo comparativamente ao trecho que retratava a situação cotidiana. A Tabela 09 abaixo reúne ambas as informações (provenientes de 52 entrevistas). 
Tabela 09 - Distribuição das respostas para cada conceito avaliado na situação hipotética

\begin{tabular}{|c|c|c|c|c|c|}
\hline $\begin{array}{l}\text { Classificação } \\
\text { Conceito }\end{array}$ & $\begin{array}{c}\text { Autonomia } \\
\text { no jogo }\end{array}$ & $\begin{array}{l}\text { Autonomia } \\
\text { em ambos }\end{array}$ & $\begin{array}{c}\text { Heteronomia } \\
\text { em ambos }\end{array}$ & $\begin{array}{c}\text { Autonomia } \\
\text { no cotidiano }\end{array}$ & $\begin{array}{c}\text { Pontuação } \\
\text { máxima }\end{array}$ \\
\hline Responsabilidade & $\begin{array}{c}06 \\
(11,53)\end{array}$ & $\begin{array}{c}25 \\
(48,07)\end{array}$ & $\begin{array}{c}09 \\
(17,3)\end{array}$ & $\begin{array}{c}12 \\
(23,07)\end{array}$ & 22 \\
\hline Justiça & $\begin{array}{c}25 \\
(48,07)\end{array}$ & $\begin{array}{c}13 \\
(25)\end{array}$ & $\begin{array}{c}13 \\
(25)\end{array}$ & $\begin{array}{c}01 \\
(1,92)\end{array}$ & 24 \\
\hline Sanção & $\begin{array}{c}04 \\
(7,69)\end{array}$ & $\begin{array}{c}15 \\
(28,84)\end{array}$ & $\begin{array}{c}15 \\
(28,84)\end{array}$ & $\begin{array}{c}18 \\
(34,6)\end{array}$ & 09 \\
\hline Mentira & $\begin{array}{c}16 \\
(30,76)\end{array}$ & $\begin{array}{c}13 \\
(25)\end{array}$ & $\begin{array}{c}15 \\
(28,84)\end{array}$ & $\begin{array}{c}08 \\
(15,38)\end{array}$ & 05 \\
\hline TOTAL & 51 & 56 & 54 & 39 & ------ \\
\hline
\end{tabular}

Num primeiro momento nos limitaremos a apontar que o conceito de justiça foi o que apresentou maior congruência entre os quesitos avaliados, sendo o item mais pontuado pelo maior número de sujeitos (24 em 52). Em seguida temos o conceito de responsabilidade, no qual 22 sujeitos se destacaram (os empates foram computados duplamente). Tomando em consideração tais conceitos vemos que para a justiça foi prevalente a defesa da igualdade no contexto de jogo $(48,07 \%)$ enquanto que ao avaliar a responsabilidade por atos danosos nossos sujeitos consideraram a intenção embutida no gesto, tanto na situação de jogo como na situação cotidiana. Isto significa, relembrando nosso roteiro de entrevista, que mais crianças consideraram igualitária a responsabilidade por trapacear e por causar algum prejuízo fazendo algo ilícito. Em contrapartida também mais crianças acharam injusto beneficiar quem ganhou o jogo ao mesmo tempo em que acharam justo dar a maior recompensa para quem fez as tarefas prontamente.

Dando continuidade a nossa análise, observamos que para o tema sanção, prevaleceu a autonomia para a situação cotidiana $(34,6 \%)$, ou seja, foram escolhidas punições mais recíprocas para esta e mais expiatórias para o jogo. Sobre isto, cabe-nos comentar que muito provavelmente a defesa da reciprocidade na situação cotidiana tenha se dado mais pelo tipo de erro que o personagem cometeu, do que realmente por tendências autônomas destes sujeitos. Recorrendo novamente ao roteiro de entrevista 
temos que a trapaça no jogo foi contraposta ao ato de furar fila, o que por muitos deles foi considerado banal, para alguns nem ao menos chegou a representar uma falta, bastando que o malfeitor retornasse a seu lugar para restaurar o dano. Fora isto, vemos que a consideração igualitária dos dois contextos hipotéticos considerados foi também expressiva, seja para a defesa da reciprocidade ou da expiação em ambos. Tal nivelamento entre respostas autônomas e heterônomas explica-se, aliás, pela própria idade dos sujeitos.

Sobre o tema da mentira, nota-se que a autonomia esteve mais presente nos juízos emitidos para situação de jogo, embora o índice de heteronomia para ambas as situações esteja bem próximo. Desta forma, vemos que a intenção de enganar não foi considerada em nenhuma das situações por grande parte da amostra, e quando o foi, o foi mais no jogo. Vale acrescentar que, considerando o conjunto de respostas dadas à comparação entre a "mentira do desenho" e a "mentira da queimada" (vide roteiro) houve equivalência entre as duas, sendo que 17 sujeitos acharam pior a do desenho, contra 15 que condenaram a da queimada (12 acharam as duas ruins e 8 entraram em contradição).

Lendo agora a mesma Tabela 09 na vertical observamos que os juízos autônomos foram prevalentes na situação de jogo quando associados ao tema da justiça $(48,07 \%)$ e da mentira $(30,76 \%)$, e na situação cotidiana quando abordados os conceitos de responsabilidade $(23,07 \%)$ e sanção $(34,6 \%)$. Tais conceitos também foram predominantes na avaliação igualitária das duas situações com base na autonomia. Em contrapartida, a mentira e, novamente, a sanção se sobressaem quando ambas as situações são concebidas heteronomamente.

Pretendeu-se neste tópico fazer apenas um apanhado geral dos conteúdos enunciados pelos sujeitos durante a entrevista, dando-se mais atenção para a qualidade 
das respostas obtidas do que para o número de ocorrências da mesma. Com isto, pudemos, minimamente, demonstrar algumas sutilezas do status dado à regra quando associada hipoteticamente a conteúdos morais, seja no jogo ou no cotidiano.

De maneira geral, foram encontradas variações interessantes no julgamento das crianças para situações cotidianas e situações de jogo a depender do conceito em pauta. Vimos, por exemplo, o quão mais facilmente elas fazem prevalecer a igualdade no jogo do que para as obrigações domésticas, e como muitas vezes tendem a ser mais severas com os deslizes e mentiras cometidas ao jogar. Entretanto, foram igualmente relevantes as demonstrações de coerência entre jogo e cotidiano em muitos dos aspectos considerados, inclusive a incidência de respostas de autonomia em ambos os contextos superou as demais. Tais diferenças podem ser indicativas de uma construção em curso, que progressivamente aponta para a conquista ou consolidação de tendências autônomas em sua totalidade, ou seja, para o desenvolvimento continuo da moralidade em seus diferentes domínios. 


\section{8- CONSIDERAÇÕES FINAIS}

Tendo em vista a multiplicidade de comentários, conceituações, análises e discussões expostas desde o início de nossa tese até aqui, e dada como certa a probabilidade de não termos estendido ou esclarecido suficientemente muitas delas, premente se faz, neste momento, retomar alguns pontos de nosso percurso a fim de, não somente completá-los, mas também articulá-los e, quem sabe, melhor arrematá-los.

Tamanho intento exige, antes de qualquer coisa, que retomemos os propósitos embutidos em nossas linhas e entrelinhas, pois só assim poderemos nos certificar da relevância do conteúdo a ser exposto.

Pois bem, foi colocado em primeiro plano que esta pesquisa abordaria o desenvolvimento moral infantil, em uma perspectiva piagetiana a partir do estudo da relação da criança com regra, por meio da temática dos jogos de regras. Como forma de fundamentar tal proposta recorreu-se a textos de Piaget que expusessem a vertente sociológica de sua teoria, na busca de uma melhor definição do papel da regra e da troca social para o desenvolvimento infantil.

Importante se fez também a articulação com autores contemporâneos não só da Psicologia como também de outras áreas, no sentido de discutir o status da regra enquanto dado objetivado (lei, formulação verbal) e mecanismo regulador (referencial compartilhado, acordo consensual), seja ela um regulamento (como no jogo) ou um princípio (como na moral).

Procurou-se, ainda, apresentar um breve levantamento bibliográfico como garantia tanto da inserção da pesquisa quanto de seu diferencial no campo científico, delimitando-o frente a outros trabalhos com temáticas semelhantes, em especial os que abordam o uso de jogos em suas relações com o desenvolvimento moral. 
Feito isto, partimos em busca da delimitação de nossas premissas e hipóteses, para então justificarmos os caminhos metodológicos escolhidos e selecionarmos dentre as informações coletadas aquelas que, por ventura, fossem suficientemente elucidativas do fenômeno investigado. Donde surge a pergunta: Chegamos onde pretendíamos?

Ante de tentar respondê-la, contudo, relembremos que este estudo objetivou analisar diferentes formas da criança praticar e conceber a regra frente a diversificados arranjos contextuais, defendendo o jogo de regras como espaço propício ao exercício cooperativo e considerando a possibilidade de uma maior manifestação de posturas autônomas em contextos com maior abertura à reciprocidade. A partir disto, foram propostas diferentes situações de contato das crianças com a regra, as quais apresentaram demandas diversificadas de flexibilização e socialização (contextos fechado, intermediário, aberto e hipotético).

Dentre tantas elucidações a se fazer é relevante ressaltar que não constou (e ainda não consta) em nossas intenções a definição de padrões e perfis de bom uso da regra, muito menos estabelecer a forma ideal ou mais avançada de praticá-la, isto, aliás, foi feito por Piaget em sua obra sobre o juízo moral na criança (1932/1994). O que se buscou foi, com base no que já se tem teórica e empiricamente estipulado sobre as condutas autônomas, acompanhar as variações destas condutas no que diz respeito a interação com a regra. Em outras palavras, não se pretendeu definir o máximo e o mínimo desempenho e sim verificar suas múltiplas manifestações. Não foi por outro motivo que concentramos nossos esforços em acompanhar cada criança em sua singularidade, deixando em segundo plano as comparações generalizantes.

Enfim, após tantos cruzamentos e ensaios descritivos dos resultados, podemos dizer que em nossas análises ficaram patentes três vias de explanações. Primeiro, o interjogo entre configurações do meio e capacidade assimilativa individual. Segundo, as 
diversas interfaces de tal assimilação (no sentido da relação entre prática e consciência da regra), com a identificação de seus conteúdos e dos fins a que se destinavam. E terceiro, a participação da relação pessoal na relação com a regra, isto é, o papel desempenhado pela possibilidade de trocas interindividuais em seu uso interpretativo e regulatório.

Com relação à primeira destas três vias, ficou demonstrado que se teve para cada contexto atuações boas e ruins, ou seja, a possibilidade de agir de modo avançado não estava dada de antemão, cabendo a cada sujeito interagir a sua maneira com as potencialidades e adversidades presentes em cada situação. Por mais que, em hipótese, a situação aberta estivesse propensa a maiores debates e a fechada menos suscetível a realização de acordos, vimos que, em alguns momentos, a vantagem foi convertida em desvantagem e vice-versa, isto é, a rigidez da situação fechada propiciou maior exatidão no recurso à regra como fonte referencial enquanto que a flexibilidade da situação aberta serviu a manipulações indevidas com o intuito de tirar vantagem.

Para além de tais especificidades e considerando de forma mais geral cada contexto, ficou constado maior avanço na situação aberta, onde prevaleceu a classificação no NIII acompanhada de maior coerência entre as três categorias estipuladas (regras, ações e pessoas), sugerindo que ambientes com maiores oportunidades de trocas cooperativas podem se constituir favoráveis ao uso e compreensão do status coletivo da regra. Tal indício ganha reforços em se tratando dos demais contextos, uma vez que no fechado ocorreu a prevalência do NI e no intermediário a equivalência entre NI e NIII.

Nossa segunda fonte de interpretações reúne um volumoso e diversificado conjunto de dados. Cabe-nos, neste ponto e a partir de tais dados, a tentativa de extrair o que tivemos de demonstrativo em termos da variabilidade de interlocuções entre prática 
e consciência da regra e suas diversas manifestações. Foi discutido a este respeito, entre outras coisas, que tanto uma quanto a outra se revestiam de diferentes sentidos a depender do contexto em que se davam. Com isto não queremos dizer que tais manifestações são produtos do meio em que ocorreram, simplesmente ponderamos que, por mais que o foco recaia sobre a capacidade assimilativa do sujeito, não se pode perder de vista o aspecto interativo de suas construções.

Vimos, assim, que uma boa prática da regra poderia se resumir ao exato cumprimento de seus comandos, consistir na habilidade de se fazer aceito ou ainda se traduzir pela dificuldade em atuar sem a devida clareza do código comum. Da mesma forma, uma conduta interpretativa (sinalizadora de maior consciência) poderia vir mais ou menos impregnada por fatores pragmáticos, adaptativos ou relacionais, quando, por exemplo, se voltava à elaboração de estratégias, servia a questionamentos e reivindicações ou buscava a mera adequação.

Vimos, também, que um avançado nível de relação com a regra pode se restringir a seu bom uso sem repercutir em adequada conscientização de seu valor social. O mesmo valendo para a capacidade de refletir sobre a regra hipoteticamente, que nem sempre vinha acompanhada de uma boa prática da mesma. Embora o oposto não tenha prevalecido, ou seja, níveis de reflexão e consciência elevados, geralmente, correspondiam a bons desempenhos em termos de aplicação para quaisquer das situações consideradas, ou seja, coerência e estabilidade caminhavam juntas. O que, por sinal, constitui outro dado relevante a ser integrado a este conjunto de explanações, uma vez que evidencia a generalização de uma mesma conduta para contextos diversos. Desta forma, mesmo em meio à multiplicidade de variações individuais e contextuais, pudemos vislumbrar certa universalidade do respeito à regra, o que vai ao encontro da perspectiva piagetiana. 
Finalmente, o terceiro ponto de debate proposto em nossas análises representa o cerne de tudo o que viemos discorrendo desde o início, pois corresponde à própria essência das teorizações piagetianas sobre o caráter social da regra, isto é, o estatuto dado às relações interpessoais.

Conforme exposto anteriormente, Piaget (1932/1994; 1954/2001; 1965/1973) discute tais questões tomando em consideração a gênese da obrigação e defendo que esta ocorreria a partir dos tipos de relações sociais vivenciadas pela criança (mais coercitivas ou mais cooperativas), as quais, por sua vez, conduziriam a qualidades distintas de respeito (unilateral ou mútuo), assim sendo o respeito à regra encerra em si o respeito à pessoa e sua qualidade dependerá do grau de reciprocidade presente na relação entre dois ou mais indivíduos. Que esta relação tenha o caráter único e insubstituível como na moral ou possa ser transferida e reproduzida enquanto código como no jogo ou no Direito não vem ao caso. O que nos importa agora é esclarecer que para se relacionar autonomamente com a regra, ou seja, consenti-la livre e conscientemente, o indivíduo precisará se posicionar também autonomamente frente às pessoas, ou seja, se relacionar pela via da reciprocidade.

Voltando agora às nossas constatações, tivemos alguns indícios demonstrativos da interveniência da relação pessoal na interação com a regra. Vimos, por exemplo, que pelo menos em metade da amostra (índice considerável em se tratando de uma faixa etária em transição) houve coerência entre tais fatores, e que o maior apelo pragmático à regra se deu exatamente na falta de maior capacidade de efetivar trocas igualitárias. Vimos também que a ampliação desta possibilidade evidenciou avanços na consideração da regra enquanto referencial coletivo e que por mais inacessível (ou inobservável) ao sujeito que fosse tal oferta, ela minimamente favoreceu atuações senão mais autônomas, pelo menos mais reflexivas frente à regra. 
Sem a menor pretensão de esgotar o assunto, mas na expectativa de ter suscitado pertinentes reflexões sobre a temática em pauta, concluímos o presente trabalho apontando algo em comum a nossas três vias de explanações e recorrente em nossas discussões, cujo significado possa, talvez, servir de preleção à nossa pergunta inicial a respeito das influências sociais do contexto sobre a relação da criança com a regra.

Em suma, tendemos a ponderar o quanto tal questão põe em jogo a própria dialética entre assimilação e acomodação, e com isso cogitar o quanto tal dialética não se encontrava refletida em certa "estabilidade versátil" apresentada por muitos de nossos sujeitos, para os quais se via o bom uso da regra em resposta às demandas contextuais atrelado à consideração permanente de seu caráter social. Não seria esta a tal conduta autônoma frente à regra que defendemos teoricamente, sendo traduzida em nossos dados por uma prática consciente passível de generalização? Foi o que nosso debate nos levou a pensar.

Pensando agora no porvir, cabe-nos apontar alguns desdobramentos possíveis que possam conduzir ao aprofundamento ou aprimoramento de nossas análises. Começando por este último, cremos interessante a replicação do estudo contando com a realização de maior número de sessões para cada contexto e a diversificação dos instrumentos utilizados em cada um, o que poderia, talvez, fornecer novos indícios acerca da generalização da relação com a regra.

No que diz respeito à continuidade de nossas investigações, julga-se pertinente o levantamento de informações sobre a relação da criança com a regra em contextos concretos de não jogo. Algo inclusive planejado para esta pesquisa, mas que por conta de empecilhos logísticos ocorridos durante a coleta dos dados não pode ser levado à frente. Acredita-se que tais informações enriqueceriam a discussão sobre a natureza da 
regra, contribuindo com sua definição enquanto código prescrito e como mecanismo regulador. 


\section{9- REFERÊNCIAS}

ALENCAR. H. M. A moralidade e os sentimentos. In: QUEIROZ, S. S.; ORTEGA, A. C.; ENUMO, S. R. F. (orgs.). Desenvolvimento e aprendizagem humana: temas contemporâneos. Vitória: UFES. Programa de pós-graduação em Psicologia. Linhares: UNILINHARES. Curso de Psicologia, 2005.cap. 04, p.79-104.

ALVES,I. P. Níveis de construção dialética espaço-temporal no jogo de xadrez e desenvolvimento de possíveis em escolares. $2006.136 \mathrm{f}$. Dissertação (Mestrado em Psicologia Educacional) - Faculdade de Educação, Universidade Estadual de Campinas, Campinas.

ALVES, J. M; SANTOS, J. G. W. O jogo dominó como contexto interativo para a construção de conhecimentos por pré-escolares. Psicologia Reflexão e Crítica, Porto Alegre, v. 13, n. 3, p. 383-390, 2000.

BARICCATTI,K. H. G. A construção dialética das operações de adição e subtração no jogo de regras FanTan.2003.184 f. Dissertação (Mestrado em Psicologia Educacional) - Faculdade de Educação, Universidade Estadual de Campinas, Campinas.

BATISTA, J. B. V. Diferença de sexo e influência de gênero no julgamento moral e na empatia.1997. 85 f. Dissertação (Mestrado) - Programa de pós-graduação em Psicologia, Universidade Federal da Paraíba, João Pessoa.

BERNARDES, N; KOLLER, S. Desenvolvimento das emoções morais: como as crianças expressam e compreendem suas emoções e valores?Revista brasileira de crescimento e desenvolvimento humano, São Paulo, v.13, n.2, p. 31-43, 2003.

BIAGGIO, A. M. B. Kohlberg e a "Comunidade Justa": promovendo o senso ético e a cidadania na escola. Psicologia Reflexão e Crítica, Porto Alegre, v.10, n.1, p.47-69, 1997.

BIAGGIO, A. M. B. Universalismo versus relativismo no julgamento moral. Psicologia: Reflexão e Crítica, Porto Alegre, v.12, n.1, p. 05-20, 1999.

BIAGGIO, A. M. B.Lawrence Kohlberg: ética e educação moral. São Paulo: Moderna, 2002.

BIAGGIO, A. M. B.et al. Promoção de atitudes ambientais favoráveis através de debates de dilemas ecológicos. Estudos dePsicologia, Natal, v.4, n.2, p.221-239, 1999.

BIAGGIO, A.; CAMINO, C; VIKAN, A.Orientação social, papel sexual e julgamento moral: uma comparação entre duas amostras brasileiras e uma norueguesa. Psicologia: Reflexão e Crítica, Porto Alegre, v.18, n.1, p. 01-06, 2005.

BOGATSHOV, D. N. Jogos computacionais heurísticos e de ação e a construção dos possíveis em crianças do ensino fundamental. 2001. 132f. Dissertação (Mestrado em Psicologia Educacional) - Faculdade de Educação, Universidade Estadual de Campinas, Campinas. 
BRENELLI, R. P. Observáveis e coordenações um jogo de regras: influência do nível operatório e interação social. 1986. 286f. Dissertação (Mestrado em Psicologia Educacional) - Faculdade de Educação, Universidade Estadual de Campinas, Campinas.

BZUNECK, J. A. Julgamento moral de adolescentes delinqüentes e nãodelinqüentes em relação com ausência paterna. 1979. $184 \mathrm{f}$. Tese (Doutorado) Instituto de Psicologia, Universidade de São Paulo, São Paulo.

CALO, O. A investigação psicológica sobre a moralidade. Anotações de um projeto. Estilos da clínica, São Paulo, v. IX, nº 16, p. 80-91, 2004.

CAMINO,C. et al. Desenvolvendo valores. Como crianças e pré-adolescentesassimilam os valores: cooperação,criatividade, responsabilidade e obediência. In: Congresso Brasileiro de Psicologia do Desenvolvimento, 2005, São Paulo. Anais eletrônicos. Disponível em: <http://www.msmidia.com/sbpd/congresso/Anais.com.br>. Acesso em: 01 ago.2007.

CAMINO, C.; CAMINO, L.; MORAES, R.Moralidade e socialização: estudos empíricos sobre práticas maternas de controle social e o julgamento moral. Psicologia: Reflexão e Crítica, Porto Alegre, v.16, n.1, p.41-61, 2003.

CAMPOS, M. C. R. O possível e o necessário como eixos de construção do real vistos na situação de um jogo psicodiagnóstico.Psicopedagogia, São Paulo, v. 12, n. 26, p.1620, 1993.

CARRACEDO, V. A. Jogo carimbador: esquemas de resolução e importância educacional. 1998. 92f.Dissertação (Mestrado) - Escola de Educação Física e Esportes, Universidade de São Paulo, São Paulo.

CAVAlCANTE, C. M. B. Análise microgenética da interação social e do funcionamento cognitivo de crianças por meio do jogo Matix.2006.163 f. Dissertação (Mestrado) - Programa de pós-graduação em Psicologia, Universidade Federal do Espírito Santo, Vitória.

CHATEAU, J. O Jogo e a criança. São Paulo: Summus, 1987.

COSTA, E. E. M. O jogo com regras e o lugar do pensamento operatório: um estudo com crianças pré-escolares. 1991. 230 f. Tese (Doutorado) - Instituto de Psicologia, Universidade de São Paulo, São Paulo.

DALlEGRAVE, G. M. R. O papel da identificação com o professor no desenvolvimento moral de adolescentes. 1999. 87 f.Dissertação (Mestrado) - Instituto de Psicologia, Universidade Federal do Rio Grande do Sul, Porto Alegre.

DELL'AGLI, B. A. V. O jogo de regras como um recurso diagnóstico psicopedagógico.2002. 199 f. Dissertação (Mestrado em Psicologia Educacional) Faculdade de Educação, Universidade Estadual de Campinas, Campinas.

DELVAL, J. As respostas na entrevista clínica. In: Introdução à prática do método clínico: descobrindo o pensamento das crianças. Porto Alegre: ArtMed, 2002. cap. 06, p. 137-159. 
DESSANDRE, S. A. B. A educação moral possível: o conflito como estratégia para a autonomia.2004.123 f. Dissertação (Mestrado em Psicologia Educacional) Pontifícia Universidade Católica do Rio de Janeiro, Rio de Janeiro.

DIAS, M. G. B. B. A compreensão de conceitos sociais e morais em crianças de orfanatos. Psicologia Teoria e Pesquisa, Brasília, v. 08, nº 02, p. 207-18, 1992.

DIAS, M. G. B. B. Regras morais e convencionais no raciocínio de crianças. Psicologia Teoria e Pesquisa, Brasília, v. 06, nº 02, p. 125-138, 1990.

DURKHEIM, E. (1924).Sociologia e filosofia.São Paulo: Ícone, 1994.

DURKHEIM, E. (1925). A educação moral. Petrópolis: Vozes, 2008.

ESTRAZULAS, M. B. P. Rede Jovem Paz: solidariedade a partir da complexidade. 2004. 307 f. Tese (Doutorado em Psicologia) - Universidade Federal do Rio Grande do Sul, Porto Alegre.

FONTES, A.E.H.G.T. Os níveis de compreensão interpessoal no contexto do jogo simbólico. 2004. 241 f. Tese (Doutorado) - Faculdade de Educação, Universidade Estadual de Campinas, Campinas.

FREITAS, L. B. L. A moral na obra de Jean Piaget: um projeto inacabado. 2002.159 f. Dissertação (Mestrado).Instituto de Psicologia, Universidade de São Paulo, São Paulo.

FRIAS, E. R. Jogo das representações (RPG) e aspectos da moral autônoma. 2010.110 f. Dissertação (Mestrado).Instituto de Psicologia, Universidade de São Paulo, São Paulo.

GRANDO, R.C. O conhecimento matemático e o uso de jogos em sala de aula. 2000. 224 f. Tese (Doutorado) - Faculdade de Educação, Universidade Estadual de Campinas, Campinas.

GRANDO, R.C. O jogo e suas possibilidades metodológicas no processo ensinoaprendizagem da matemática.1995. 175 f. Dissertação (Mestrado) - Faculdade de Educação, Universidade Estadual de Campinas, Campinas.

GUIMARÃES, K. P.Processos cognitivos envolvidos na construção de estruturas multiplicativas. 2004. 197 f. Tese (Doutorado) - Faculdade de Educação, Universidade Estadual de Campinas, Campinas.

GUIMARÃES, K. P. Abstração reflexiva e construção da noção de multiplicação via jogos de regras: em busca de relações. 1998. 181f. Dissertação (Mestrado) Faculdade de Educação, Universidade Estadual de Campinas, Campinas.

GUMMERUM, M. et al. Preschooler's Allocation in the Dictator Game: the role of moral emotions. Journal of Economic Psychology, v. 31. n. 1, p. 25-34, 2010.

HUIZINGA, J. (1938). Homo ludens: o jogo como elemento da cultura. 4. ed. São Paulo: Perspectiva, 1993. 
KISHIMOTO, T. M. O jogo e a educação infantil. São Paulo: Pioneira, 1998.

KOLLER, S.Diferenças no nível de julgamento moral entre menores institucionalizados infratores e não-infratores. Estudos de Psicologicos,Campinas, v.6, n.1, p.127-134, 1989.

KOLLER, S; PALUDO, S. S. Emoções Morais e Gratidão: uma nova perspectiva sobre o desenvolvimento de jovens que vivem em situação de risco pessoal e social. 2008. 221 f. Tese (Doutorado) - Instituto de Psicologia, Universidade Federal do Rio Grande do Sul, Porto Alegre.

LA TAILlE, Y. Para um estudo psicológico das virtudes morais. Educação e Pesquisa, São Paulo, v.26,n.1, p. 109-121, 2000.

LA TAILlE, Y. Desenvolvimento moral: a polidez segundo as crianças. Cadernos de Pesquisa, São Paulo, s/v,n. 114, p. 89-119, 2001 a.

LA TAILLE, Y. A questão da indisciplina: ética, virtudes e educação. In: DEMO, P.; LA TAILlE, Y.; HOFFMANN, J. (Orgs.). Grandes pensadores em educação: o desafio da aprendizagem, da formação moral e da avaliação. Porto Alegre: Mediação, 2001b. p. 67-98.

LA TAILLE, Y. Vergonha, a ferida moral. Petrópolis: Vozes, 2002.

LA TAILLE, Y. A importância da generosidade no início da gênese da moralidade na criança. Psicologia: Reflexão e Crítica, Porto Alegre, v.19, n.1, p. 09-17, 2006.

MACEDO, L. Teoria da equilibração e jogo. In: (org). Jogos, psicologia e educação: teoria e pesquisas.São Paulo: Casa do Psicólogo, 2009. cap. 03, p. 45-66.

MACEDO, L. O lúdico nos processos de desenvolvimento e aprendizagem. In: MACEDO, L; PETTY, A. L. S.; PASSOS, N. C. Os jogos e o lúdico na aprendizagem escolar. Porto Alegre: Artmed, 2005. cap. 01, p. 09-22.

MACEDO, L. Os jogos e sua importância na escola. Cadernos de Pesquisa, São Paulo, n. 93, p. 5-10, 1995.

MACEDO, L. Ensaios Construtivistas. São Paulo: Casa do Psicólogo, 1994.

MACEDO, L;PETTY, A. L. S.; PASSOS, N. C.. Os jogos e o lúdico na aprendizagem escolar. Porto Alegre: Artmed, 2005.

MACEDO, L.; PETTY, A. L. S.; PASSOS, N. C. Aprender com jogos e situações problemas. Porto Alegre: Artmed, 2000.

MACEDO, L.; PETTY, A. L. S.; PASSOS, N. C. Quatro cores, senha e dominó: oficinas de jogos em uma perspectiva construtivista e psicopedagógica. São Paulo: Casa do Psicólogo, 1997.

MAGALHÃES, L.A.M. O jogo cara a cara a cara em crianças de 07 a13 anos: uma análise construtivista. 1999. 96 f. Dissertação (Mestrado) - Faculdade de Educação, Universidade de São Paulo, São Paulo. 
MARTINS, R. A. Concepções sobre regras morais e convencionais em crianças de préescola e do primeiro grau. Psicologia Teoria e Pesquisa, Brasília, v. 11, no 03, p. 203 $211,1995$.

MELO, M. E. C. A construção de regras no jogo infantil: um estudo em aulas de Educação Física das $\mathbf{1}^{\mathbf{a}}$ e $\mathbf{2}^{\mathbf{a}}$ séries do primeiro grau. 1993. 96f. Dissertação (Mestrado em Psicologia Educacional) - Faculdade de Educação, Universidade Estadual de Campinas, Campinas.

MENIN, M. S. S.Desenvolvimento moral: refletindo com pais e professores. In: MACEDO, L. (org.). Cinco estudos de educação moral. São Paulo: Casa do Psicólogo, 1996. cap.02, p. 37-100.

MENIN, M.S.S. Autonomia e heteronomia às regras escolares: observações e entrevistas na escola. 1985. 215 f. Dissertação (Mestrado) - Instituto de Psicologia, Universidade de São Paulo, São Paulo.

MORETTO, A. L.L.O conceito de moral e o nível de julgamento moral, manifesto nas enunciações de adolescentes de diferentes níveis sócio-econômicos, diante de um dilema moral. 2003. 125 f. Dissertação (Mestrado) - Programa de pós-graduação em Psicologia, Universidade Católica de Brasília, Brasília.

OLIVEIRA, F.N. Um estudo das interdependências cognitivas e sociaisem escolares de diferentes idades por meio do jogoxadrez simplificado. 2005. $311 \mathrm{f}$. Tese (Doutorado) - Faculdade de Educação, Universidade Estadual de Campinas, Campinas.

ORTEGA, A. C.et al.Aspectos psicogenéticos do pensamento dialético no jogo Mastergoal.In: NOVO, H. A. e MENANDRO, M. C. S. (orgs.). Olhares diversos: estudando o desenvolvimento humano. Vitória: UFES. Programa de pós-graduação em Psicologia. CAPES. PROIN, 2000. cap. 04, p.73-90.

PALHARES, O. Análise de processos cognitivos em crianças no jogo Traverse. 2003.214 f. Dissertação (Mestrado em Psicologia Educacional) - Faculdade de Educação, Universidade Estadual de Campinas, Campinas.

PAULETO, C.R.P. Jogos de regras como meio de intervenção na construção do conhecimento aritmético em adição e subtração. 2001. 133 f. Dissertação (Mestrado em Psicologia Educacional) - Faculdade de Educação, Universidade Estadual de Campinas, Campinas.

PESSOTTI, A.M. Moralidade e trapaça: um estudo com crianças de 5 e 10 anos.2010.152 f. Dissertação (Mestrado) - Programa de pós-graduação em Psicologia, Universidade Federal do Espírito Santo, Vitória.

PETTY, A. L. S.; PASSOS, N. C. Algumas reflexões sobre jogos de regras. In: SISTO, F. F (Org.). Atuação psicopedagógica e aprendizagem escolar. Petrópolis: Vozes, 1996. cap. 09, p. 163-174.

PIAGET, J (1975). A equilibração das estruturas cognitivas: problema central do desenvolvimento. Rio de Janeiro: Zahar, 1976. 
PIAGET, J (1972). Para onde vai a Educação? 12. ed. Rio de Janeiro: José Olympio, 1994.

PIAGET, J. (1967). Biologia e conhecimento. Petrópolis: Vozes, 1973.

PIAGET, J. (1966). A linguagem e o pensamento na criança. São Paulo: Martins Fontes, 1999.

PIAGET, J. (1965). Estudos sociológicos. Rio de Janeiro: Forense, 1973.

PIAGET, J. (1964). Seis estudos de psicologia. 17 ed. São Paulo: Forense Universitária, 1989.

PIAGET, J (1954). Inteligência e afectividad. Buenos Aires: Aique, 2001.

PIAGET, J. (1946). A formação do símbolo na criança: imitação, jogo e sonho, imagem e representação. 3. ed. Rio de Janeiro: Zahar, 1978.

PIAGET, J. (1932). O juízo moral na criança. 3. ed. São Paulo: Summus, 1994.

PIANTAVINI, F.N.O. Jogo de regras e construção de possíveis: análise de duas situações de intervenção psicopedagógica. 1999. [s.n]. Dissertação (Mestrado em Psicologia Educacional) - Faculdade de Educação, Universidade Estadual de Campinas, Campinas.

PONTES, F. A. R.; GALVÃO, O. F. Desenvolvimento do seguimento de regras no jogo de peteca (bola de gude). Psicologia Teoria e Pesquisa, Brasília, v. 13, n. 2, p. 231237, 1997.

QUEIROZ, S. S. Inteligência e afetividade na dialética de Jean Piaget: um estudo com o jogo da Senha. 2000. 223 f. Tese (Doutorado) - Instituto de Psicologia, Universidade de São Paulo, São Paulo.

QUEIROZ, S. S.; RONCHI, J. P. e TOKUMARU, R. S. Constituição das regras e o desenvolvimento moral na teoria de Piaget: uma reflexão kantiana. Psicologia Reflexão e Crítica, v.22, n.1, p. 69-75, 2009.

RABIOGLIO, M. B. Jogar: um jeito de aprender - análise do pega-varetas e da relação jogo/escola. 1995. 163 f. Dissertação (Mestrado) - Faculdade de Educação, Universidade de São Paulo, São Paulo.

RIBEIRO, M. P. O. Funcionamento cognitivo de criança com queixas de aprendizagem: jogando e aprendendo a jogar. 2001. 187f. Tese (Doutorado) Instituto de Psicologia, Universidade de São Paulo, São Paulo.

ROSSETTI, C.B. O pensamento dialético no jogo de regras: uma abordagem piagetiana.1996.112 f. Dissertação (Mestrado) - Programa de pós-graduação em Psicologia, Universidade Federal do Espírito Santo, Vitória.

ROSSETTI, C. B.; SOUZA, M. T. C. C. Jogos de regras e cognição: uma revisão da produção de três grupos de pesquisa brasileiros.In: QUEIROZ, S. S.; ORTEGA, A. C.;ENUMO, S. R. F. (orgs.). Desenvolvimento e aprendizagem humana: temas 
contemporâneos. Vitória: UFES. Programa de pós-graduação em Psicologia. Linhares: UNILINHARES. Curso de Psicologia, 2005. cap. 02, p.27-44.

ROSSETTI, C. B.; RIBEIRO, M. P. O. Os jogos de regras em uma abordagem piagetiana: o estado da arte e as perspectivas futuras. In: MACEDO, L. (org). Jogos, psicologia e educação: teoria e pesquisas.São Paulo: Casa do Psicólogo, 2009. cap. 01, p. 11-33.

SANTOS, C. C. Análise microgenética de aspectos do funcionamento cognitivo de adolescentes e de idosos por meio do jogo Quoridor. 2007.126 f. Dissertação (Mestrado) - Programa de pós-graduação em Psicologia, Universidade Federal do Espírito Santo, Vitória.

SALES, E. M. B.O conceito de justiça distributiva relacionado às normas sociais escolares. Psicologia: Reflexãoe Crítica, Porto Alegre, v.13, n.1, p. 49-58, 2000.

SILVEIRA, C. A. F. Os processos inferenciais via jogos de regras na compreensão da leitura. 2004. 170f. Dissertação (Mestrado em Psicologia Educacional) - Faculdade de Educação, Universidade Estadual de Campinas, Campinas.

SOARES, J. F. R. O julgamento moral; a tomada de perspectiva do outro e a consideração empática: um estudo correlacional. 1996. 127 f. Dissertação (Mestrado) - Programa de pós-graduação em Psicologia, Universidade Federal da Paraíba, João Pessoa.

SOUZA, M. T. C. C. Cultura, cognição e afetividade: inter-relações em diferentes perspectivas. A interação social e os objetos "afetivos" na perspectiva piagetiana de construção do conhecimento. In: LEITE, S. A. S. (org.). Cultura, cognição e afetividade: a sociedade em movimento. São Paulo: Casa do Psicólogo, 2002.

SOUZA, M. T. C. C. Natureza e cultura: reflexões a partir da teoria de Jean Piaget. In: CARVALHO, A. M. (org.). O mundo social da criança: natureza e cultura em ação. São Paulo: Casa do Psicólogo, 1999.

TEIXEIRA, R. Um estudo sobre a interação social em pré-escolares. 1997. 103f. Dissertação (Mestrado em Psicologia Educacional) - Faculdade de Educação, Universidade Estadual de Campinas, Campinas.

TICHY, M. et al. The impacto $\mathrm{f}$ constructive controversy on moral development. Journal of Aplplied Social Psychology, v.40, n.4, p. 765-787, 2010.

TURIEL, E. The culture of morality: social development, context and conflict. New York: Cambridge University Press,2002. [recursoeletrônico]

TURIEL, E. EI desarrollodelconocimiento social moralidad y convención. Madrid : Editorial Debate, 1984.

VALE, L. G. Desenvolvimento moral : a generosidade sob a ótica de crianças e adolescentes. 2006.112 f. Dissertação (Mestrado) - Programa de pós-graduação em Psicologia, Universidade Federal do Espírito Santo, Vitória. 
VON ZUBEN, R. B. A construção dialética no jogo de regras Traverse em alunos com queixas de dificuldades escolares. 2003. 229 f. Dissertação (Mestrado em Psicologia Educacional) - Faculdade de Educação, Universidade Estadual de Campinas, Campinas.

ZAIA, L. L. A solicitação do meio e a construção das estruturas operatórias em crianças com dificuldades de aprendizagem. 1996.270f. Dissertação (Mestrado em Psicologia Educacional) - Faculdade de Educação, Universidade Estadual de Campinas, Campinas. 


\section{ANEXO 01 \\ Protocolo do Contexto 03}

(Situação aberta)

Objetivo: Analisar as trocas relacionais a partir de regras elaboradas pelas próprias crianças.

Materiais: As cartas que compõe o material Conte um conto, um dado, pinos e um tabuleiro com percurso numerado.

Descrição: Solicita-se às crianças que inventem um jogo e elaborarem as regras.Para tanto são utilizadas algumas questões norteadoras como, por exemplo:

- Se você fosse jogar com estes materiais como você jogaria?

- Quais materiais vocês desejam usar. Para que servirá o dado? E as cartas? (...)

- Qual será o objetivo do jogo?

- Como termina o jogo? Como saberemos quem ganhou e quem perdeu?

- Como será definida a ordem de quem joga?

- O que vale e o que não vale?

- O que acontece se...(o outro não conseguir completar a jogada, parar na casa 10, tirar seis no dado, esquecer-se de jogar na sua vez, pular a vez do colega, tirar a carta coringa, etc.).

*OBS: Se necessário sugere-se ao grupo algumas maneiras de jogar (neste caso é informado que o objetivo do jogo é inventar estórias).

$1^{a}$ cartas viradas sob a mesa, o jogador da sua vez sorteia uma e continua a estória.

$2^{\mathrm{a}}$ cada um pega uma (ou três) carta antecipadamente e na sua vez continua a estória (elimina o fator surpresa).

$3^{\mathrm{a}}$ cada um pega uma carta e constroem a estória coletivamente.

$4^{\mathrm{a}} \mathrm{O}$ jogador da vez sorteia seis cartas, usa três para contar a estória e os demais precisam adivinhar quais cartas foram utilizadas. 


\section{ANEXO 02}

\section{Roteiro da entrevista clínica}

\section{$\underline{1^{\mathrm{a}} \text { estória (Responsabilidade): }}$}

A- Conhece o jogo de damas? Sabe como joga? Conhece as regras? Lembra-se daquela de não poder andar nem comer para trás no tabuleiro?

B- Então, estavam o João e o Pedro jogando o jogo de damas. O João sabia que não podia comer para trás, mas aproveitou que o Pedro não estava olhando e comeu uma pecinha para trás. Já o Pedro não sabia que não podia comer para trás, na sua vez, andou para trás e comeu três pecinhas sem que seu adversário notasse. Será que temos um mais errado que o outro? Qual dos dois está mais errado? Por quê?

C- Depois que eles terminaram de jogar cada um foi para sua casa. Quando chegou em casa Pedro foi ajudar sua mãe a lavar a louça, mas ao abrir a porta da cozinha esbarrou na mesa onde havia dez copos que caíram e quebraram. Já o João foi pegar um biscoito no armário enquanto sua mãe não estava por perto, subiu numa cadeira e ao tentar apanhá-lo derrubou um prato, que quebrou. E agora, será que temos um mais errado que o outro? Qual dos dois está mais errado? (ou "Qual você puniria mais?").

D- Você lembra o que o João fez no jogo? O que você acha disto? E o que ele fez em casa, você se lembra? O que você achou disto? Para você ele fez mais errado em casa ou no jogo? Por quê? (O João deve ser mais punido por ter comido uma pecinha para trás no jogo sabendo que não podia ou por ter quebrado um prato quando subiu na cadeira para pegar o biscoito, enquanto que sua mãe não estava?)

Demonstração da prancha ilustrativa utilizada (formato reduzido)
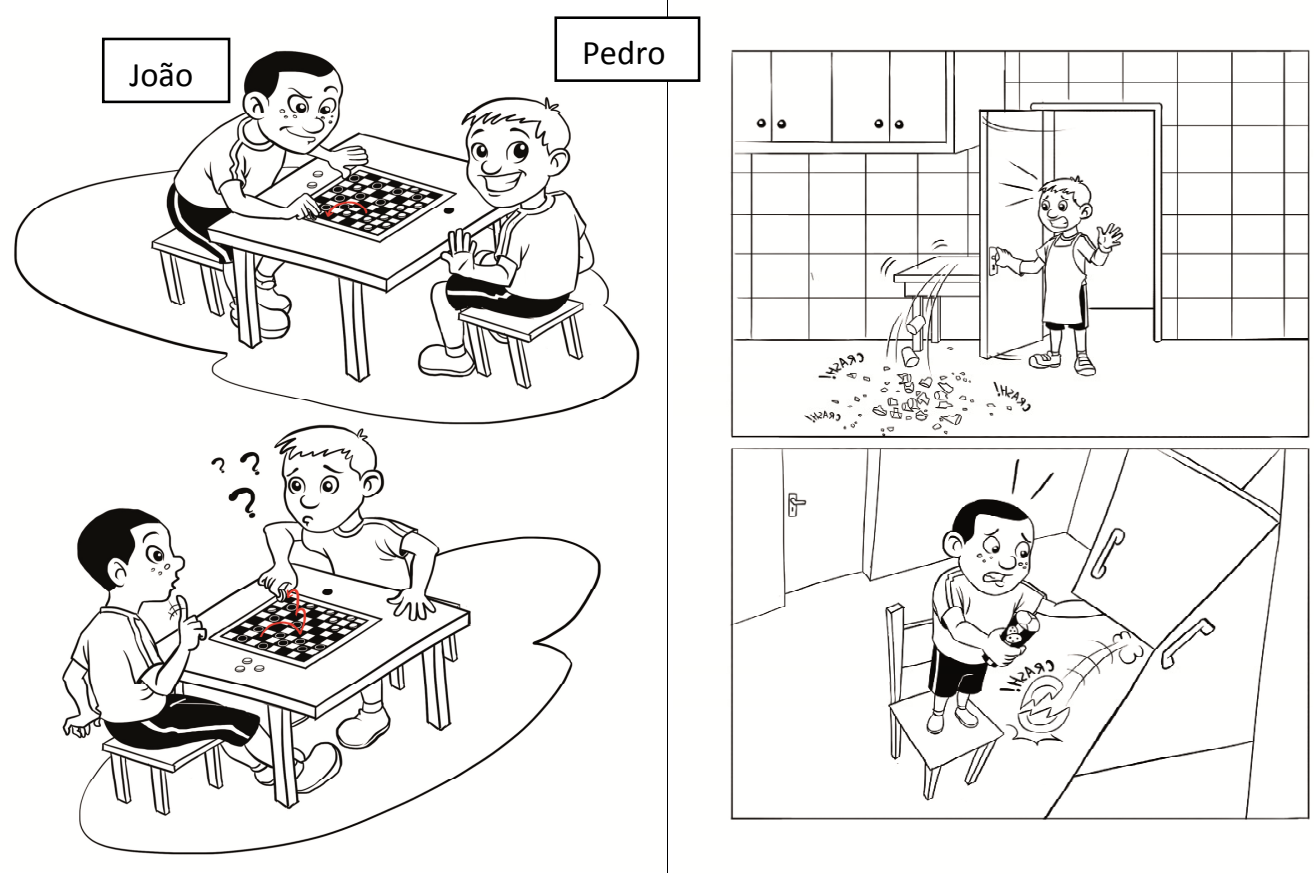
$\underline{2^{a} \text { estória (Justiça): }}$

A- Você conhece o jogo pega-varetas? Sabe como joga? Conhece as regras?

B- Dois irmãos estavam jogando pega-varetas. Luiz tomou muito cuidado e conseguiu fazer 30 pontos, mas Carlos foi mais habilidoso pegou a vareta preta e conseguiu 50 pontos. O pai observava o jogo e, a partir do resultado, decidiu distribuir 06 balas entre os meninos. Como você acha que ele deve dividir as balas? (Tem que dividir igual para todos? Quantas balas cada um deve ganhar?) Por quê?

C- Na verdade, ele deu 04 balas ao Carlos que fez mais pontos e 02 balas para o Luiz

D- Numa outra casa, havia também dois irmãos. O Felipe fazia todas as tarefas que seu pai pedia. O Júlio só fazia algumas tarefas depois de brincar com seus amigos. Um dia o pai trouxe do trabalho uma caixa com 06 bombos. Como ele deve dividir os bombos? (Tem que dividir igual para todos? Quantos bombons cada um deve ganhar? Por quê?

E- Na verdade, ele deu 04 bombons ao Felipe que fazia todas as tarefas e 02 bombons para o Júlio que só fazia algumas tarefas depois de brincar. Foi justo? Por quê?

F- Você lembra o que o pai do Carlos e do Luiz fez? Você lembra o que o pai do Julio e do Felipe fez? Para você algum deles foi mais justo ou mais injusto? Qual deles? Por quê? (Qual dos dois pais foi mais injusto/justo o do jogo ou o das tarefas? Você acha certo dar mais recompensa para quem fez mais pontos no jogo? E para quem fez as tarefas antes de brincar?).

Demonstração da prancha ilustrativa utilizada (formato reduzido)
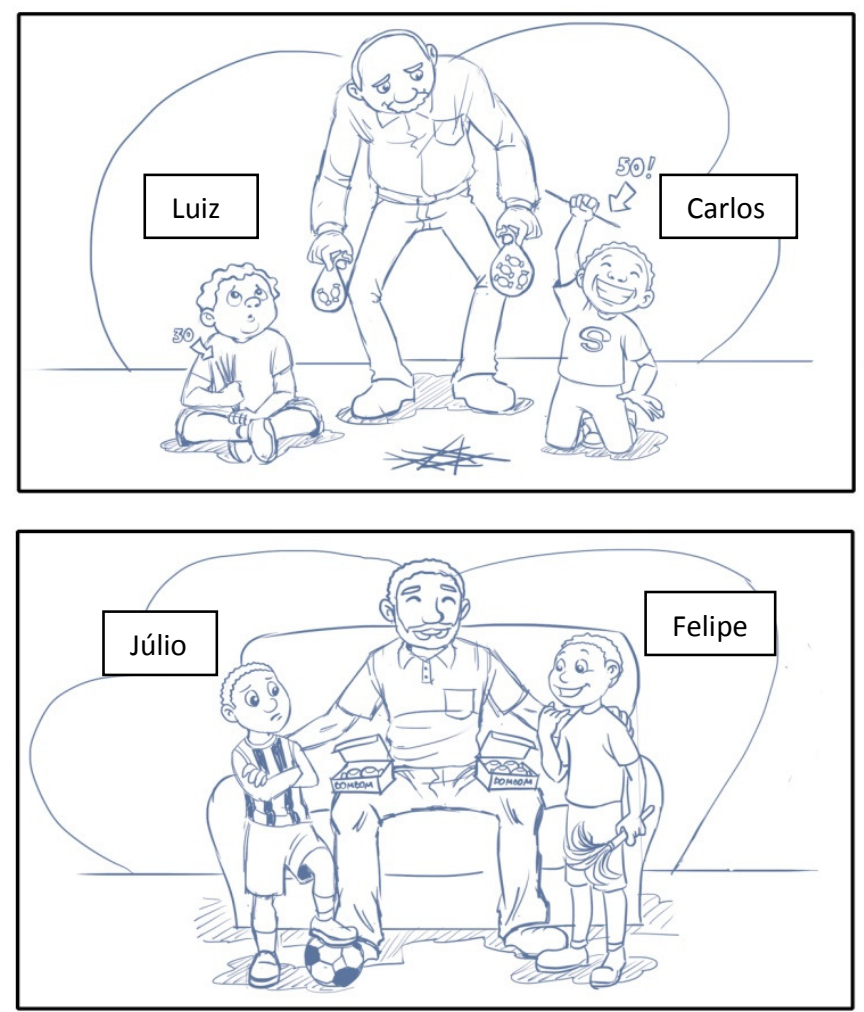


\section{$\underline{3^{a} \text { estória (Sanção): }}$}

A- Um dia uma professora decidiu deixar seus alunos jogarem jogo da memória na aula. Você conhece este jogo? Sabe como joga?

B- O Vitor estava jogando contra o Mateus. Acontece que toda vez que o Mateus se distraía o Vitor aproveitava e virava três peças ao invés de duas. Até uma hora que a professora viu. O que você acha que a professora deve fazer? Ela deve punir o Vitor? Se você fosse o professor(a) qual castigo daria?

$C$ - Na verdade a professora pensou nas seguintes punições: $1^{\mathrm{a}}$ Deixá-lo sem recreio; $2^{\mathrm{a}}$ Deixar que o Mateus olhe uma peça a mais na sua vez; $3^{a}$ Dizer ao Vitor que não irá puni-lo, mas que se ele continuar agindo assim, poder ser que ninguém queira mais jogar com ele. Qual das sanções é a menos justa? Por quê? E a mais justa? Por quê?

D- Depois quando eles foram lanchar, um outro menino chamado Gabriel furou fila e passou na frente de todos. O que você acha que o professor deve fazer? Ele deve punir o Gabriel? Se você fosse o professor(a) qual castigo daria?

E- $\mathrm{Na}$ verdade o professor pensou nas seguintes punições: $1^{\mathrm{a}}$ Fazê-lo esperar colocando-o no último lugar da fila; $2^{a}$ Deixá-lo sem lanchar; $3^{a}$ Num dia em que ele fosse o primeiro da fila, deixar que três colegas passem na frente dele. Qual das sanções é a menos justa? Por quê? E a mais justa? Por quê? (Qual é a mais errada?)

F- Você lembra o que Vitor fez na hora do jogo de memória? O que você acha disto? Você lembra o que o Gabriel fez na fila do lanche? O que você acha disto? Você acha que tem um mais errado que o outro? Qual deles fez mais errado? Por quê? (Se você fosse o professor(a) quem você castigaria mais o Vitor ou o Gabriel?)

Demonstração da prancha ilustrativa utilizada (formato reduzido)
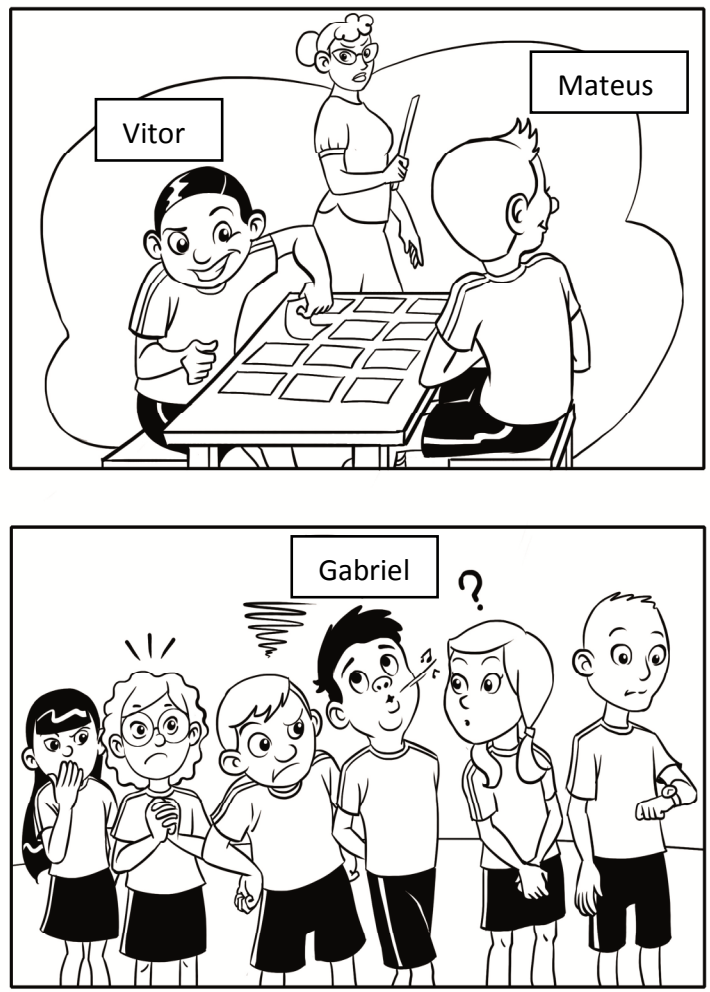


\section{$\underline{4^{\mathrm{a}} \text { estória (Mentira): }}$}

A- Tinha um menino chamado Fred que não sabia desenhar muito bem, mas que queria muito saber desenhar. Um dia estava vendo um desenho que outra pessoa fizera e disse ao seu colega: "fui eu quem fez este desenho!" Você acha que ele contou uma mentira? Por quê?

B- Num outro dia ele estava passeando na rua e encontrou um enorme cachorro. Voltou para casa e disse ao seu irmão que havia visto um cachorro tão grande como uma vaca. E agora ele mentiu? Por quê?

C- Para você temos uma mentira mais grave que a outra? Onde o Fred foi mais mentiroso, ao falar que o desenho era dele ou ao falar que tinha visto um cachorro maior que uma vaca?

D- Outro menino chamado Guto estava jogando queimada com seus amigos. Você conhece este jogo? Como se joga?

E- Teve uma hora que a bola encostou nele de raspão, mas como ninguém viu direito ele disse que ela não tinha encostado. Você acha que ele contou uma mentira? Por quê?

F- Num outro dia ele(a) estava jogando futebol e fez um bonito gol. Então disse aos seus colegas que para fazer o gol correu mais rápido que um leão. E agora ele mentiu? Por quê?

G- Para você temos uma mentira mais grave que a outra? Onde o Guto foi mais mentiroso, ao falar que a bola não havia encostado nele ou ao falar que tinha corrido mais rápido que um leão?

H- Você se lembra do que o Fred disse sobre o desenho? E o que o Guto disse na hora da queimada? Você acha que um contou mais mentira que o outro? Qual? Por quê? (Qual dos dois você puniria mais? Você puniria o Guto por não ter dito a verdade na hora do jogo? E o Fred por não ter dito a verdade sobre o desenho?).

\section{Demonstração da prancha ilustrativa utilizada (formato reduzido)}
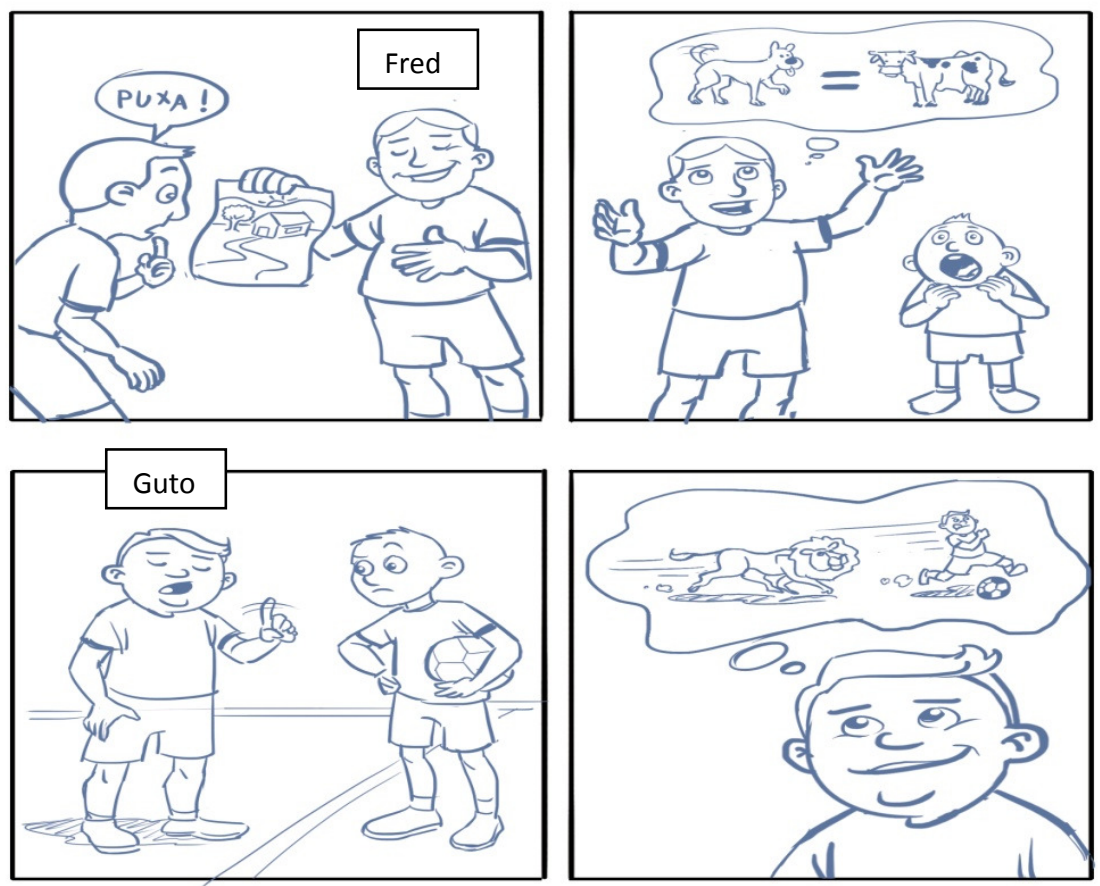


\section{ANEXO 03 \\ Situação Fechada (Jogo Ludo)}

Descrição: Ludo é uma versão ocidental popular do antigo jogo hindu Pachisi. Pode ser jogado por dois, três ou quatro jogadores (no caso de quatro, é possível formar duas duplas). O tabuleiro quadrado tem um percurso em forma de cruz e cada jogador tem quatro peões. Um dado define os movimentos. ${ }^{12}$

Regras: 1-Os peões de cada jogador começam na base de mesma cor. O objetivo do jogo é ser o primeiro a levar seus quatro peões a dar uma volta no tabuleiro e a chegar no ponto final marcado com sua cor. Os peões movem-se pelo percurso no sentido horário. 2- Para retirar um peão de sua base e colocá-lo no tabuleiro é necessário tirar um ou seis. Quando o jogador já tem pelo menos um peão no percurso, ele pode mover o peão do número de casas tirado no dado. Se tirar seis, além de usar esse resultado ele pode jogar novamente o dado. 3-Se um jogador chegar a uma casa já ocupada por um peão adversário, o peão adversário deve voltar para sua base. 4-Se o peão parar na casa com um círculo desenhado ele poderá avançar até a próxima casa com o mesmo desenho. Caso pare na casa com um X, ele deverá retroceder até a casa imediatamente anterior que também contenha um X. 5- Após dar a volta no tabuleiro o peão avança pela reta final, de sua própria cor. A chegada ao ponto final só pode ser obtida por um número exato nos dados. Se o jogador tirar mais do que o necessário, ele vai até o fim e volta, tendo que aguardar sua próxima jogada. 6- O vencedor é o primeiro a levar seus quatro peões ao ponto de chegada da sua cor.

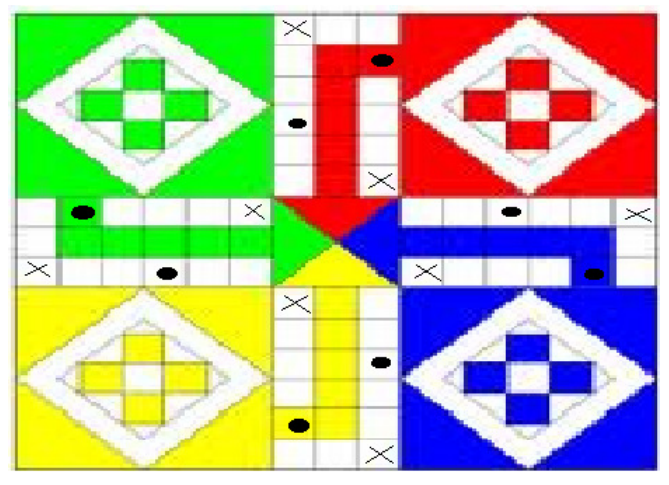

\footnotetext{
${ }^{12}$ Fonte: <http://www.regrasdosjogos.com.br>. Acesso em: 10/01/2013.
} 


\section{ANEXO 04 \\ Situação Intermediária (Jogo Uno)}

Descrição: Uno® é um jogo de cartas mundialmente famoso Uno, desenvolvido por Merle Robbins e familiares em 1971 e vendido atualmente pela Mattel. Para jogar é necessário um baralho próprio para o jogo, composto por $108 \operatorname{cartas}^{13}$.

Regras: 1- Ganha quem conseguir livrar-se o quanto antes de todas as cartas de sua mão e usar as cartas de ação para evitar que os adversários façam o mesmo. 2- Para decidir quem começa, cada jogador recebe uma carta do baralho, aquele que receber a maior carta será o primeiro a jogar, o jogo segue no sentido horário. 3- As cartas são embaralhadas e cada jogador recebe sete cartas, as que restaram são viradas para baixo e formam a pilha de compras. A primeira carta desse monte é virada para cima numa pilha ao lado - a pilha de descarte. 4- Cada jogador deve jogar uma carta que seja da mesma cor ou que tenha o mesmo símbolo/número da carta virada na pilha de descarte. Caso não tenha nenhuma carta que satisfaça essas condições, o jogador deverá comprar uma carta da pilha de compras e, se a carta for jogável, ele pode escolher por jogar ou colocar ela em sua mão. 5- Quando o jogador ficar com apenas uma carta, ele deverá falar "UNO". Caso ele não fale e outro jogador note, então aquele jogador deverá comprar três cartas. 6- As cartas de ação modificam essa ordem natural e devem ser usadas estrategicamente: "Compra duas cartas" - O próximo jogador deve comprar duas cartas e perde o seu turno, caso o jogador que foi afetado tiver outra carta como esta, ele poderá jogá-la, o jogador seguinte deverá então comprar quatro cartas e assim por diante. "Salta"- O próximo jogador perde o seu turno. "Inverte"- A ordem é invertida de horária para anti-horária e vice-versa. "Muda de cor"- O jogador escolhe uma cor e o próximo a jogar deverá jogar uma carta da cor escolhida. "Compra 4"- o próximo jogador deverá comprar 4 cartas e perde o seu turno.

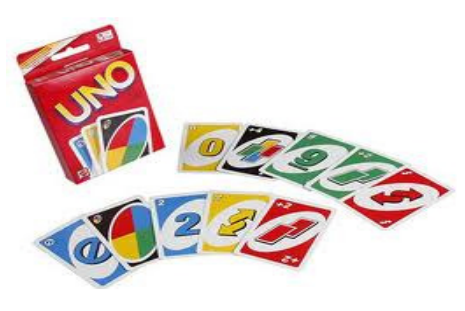

${ }^{13}$ Fonte: <http://jogosdecartas.hut.com.br/uno>. Acesso em: 10/01/2013. 


\section{ANEXO 05 \\ Planilhas da tabulação geral dos dados \\ (Gravadas em CD-ROM)}

\section{$\underline{\text { Descricão das planilhas }}$}

GRUPO 01 a GRUPO 14: Tabulação dos indicadores por grupo.

M1 Pes por Jg e M2 Jg por Pes: Matrizes utilizadas para montar o resumo.

Resumo: Tabulação dos indicadores por sujeito (reúne as 14 primeiras planilhas), mais entrevistas. Inclui também a quantidade e tipo de indicadores ocorridos em cada contexto. Sendo: $\mathrm{L}=$ Ludo (situação fechada). U = Uno (situação intermediária). $\mathrm{S}=$ Situação aberta (protocolo).

Classificação por jogo: indica os níveis dos sujeitos para cada situação (fechada, intermediária e aberta), segundo os critérios de distribuição de peso descritos no capítulo do Método. Sendo: $\mathrm{R}=$ relações com a regra. $\mathrm{A}=$ relações entre ações no jogar. $\mathrm{P}=$ Relação entre pessoas

Classificação por categoria: descreve os níveis dos sujeitos para cada categoria (regra, ações e pessoas), segundo os critérios de distribuição de peso descritos no capítulo do Método.

Suj. por níveis: Demonstra o percurso dos sujeitos segundo a classificação obtida em cada um dos critérios estabelecidos (gráficos individuais). 